\title{
Opening and Balancing the Books: the New Zealand Parliament and the Control and Scrutiny of Government Expenditure
}

\author{
By Alexander Sylvan Thomas
}

A thesis submitted to Victoria University of Wellington in fulfilment of the requirements for the degree of

Master of Arts in Political Science

Victoria University of Wellington 


\begin{abstract}
Controlling and scrutinising government expenditure is an important duty of the New Zealand Parliament. There is an on-going debate on the effectiveness of Parliament in undertaking this. The role, inherited from the British Parliament, has been developed upon and refined by the New Zealand Parliament. Parliament holds the government to account for its expenditure through a system consisting of the Finance and Expenditure Committee, other subject select committees, extensive Budget and Estimates documentation, and detailed appropriations. The Controller and Auditor-General, debate in the House, and thorough accounts and accounting are also a part of the process. The New Zealand Parliament can have more than adequate control of government expenditure, but is sometimes deficient at scrutinising its details. Recommendations to improve Parliament's ability to control and scrutinise government expenditure must centre on Members of Parliament being willing, able and eager to undertake the role.
\end{abstract}




\section{Acknowledgments}

I would like to take the opportunity to thank my supervisor, Emeritus Professor Margaret Clark, for her advice, support and assistance throughout the production of this thesis. I cannot stress enough how much I appreciated her wealth of wisdom and experience as well as her patience and assurance. It was comforting knowing that her office door was always open.

To my mum and dad, Gail and Neil, thank you for your support. Your reassurance and backing helped drive me along. I would also like to acknowledge the support of my sister, Calypso. It was inspiring to hear of your success throughout the production of this thesis.

To my postgraduate cohort, Aaron, Alice, Andrew, David, Finn, Holly and Rebekah, thank you for the encouragement and for helping me to maintain some level of sanity. I would also like to recognise my wider family, friends, and flatmates for their support and tolerance for a mind that was frequently elsewhere. I particularly want to take the opportunity to thank Holly, Pippa, Rebecca, Roy and Tiana for checking over my work.

Lastly, I want to acknowledge the Members of Parliament, public servants as well as staff at the Office of the Auditor-General and Office of the Clerk who made themselves available for interviews or provided information. I appreciate how extremely generous they were with their time and knowledge. This thesis simply would not have been the same without their contributions. The extraordinary access that New Zealanders have to the aforementioned, especially the parliamentarians, shows the strength and openness of our democracy. They are of course not responsible for the use I have made of their knowledge. 


\section{Table of Contents}

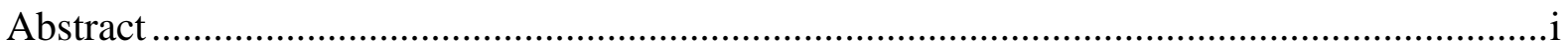

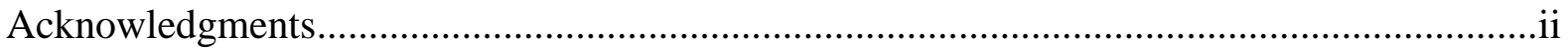

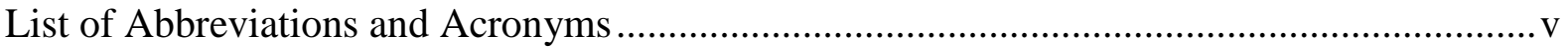

List of Figures and Tables..........................................................................................................

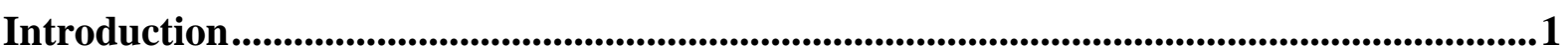

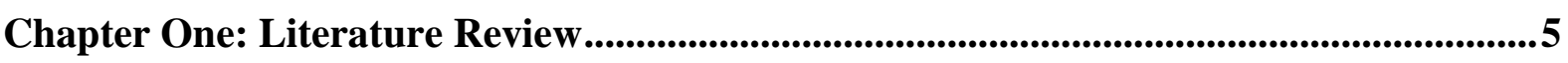

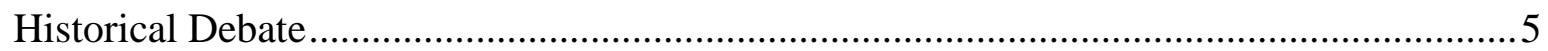

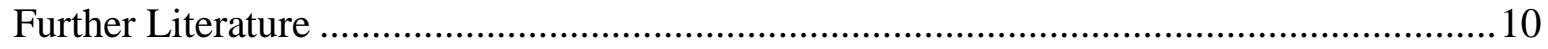

Chapter Two: History of Parliamentary Control and Scrutiny of Government

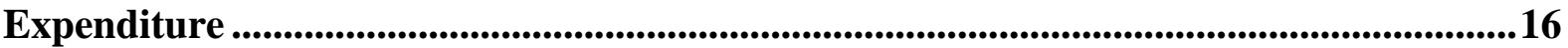

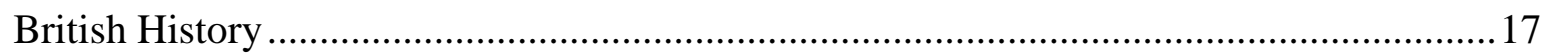

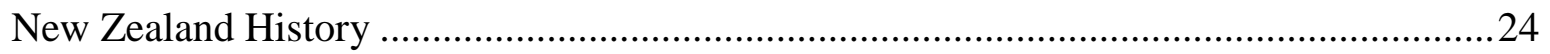

Chapter Three: Current Practice and Procedure................................................................42

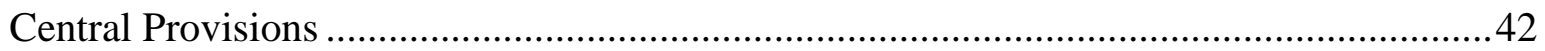

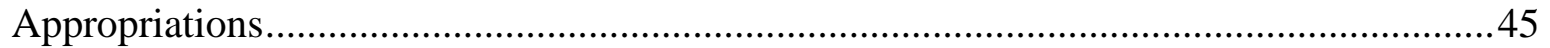

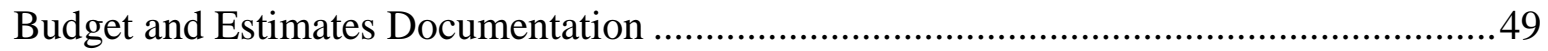

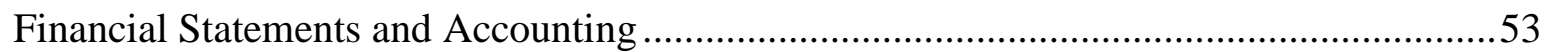

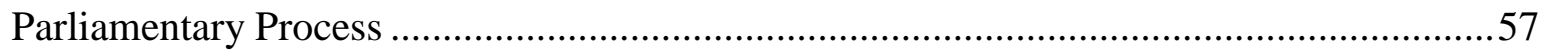

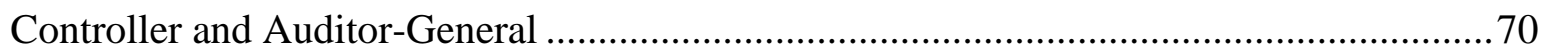

Finance and Expenditure Committee …............................................................... 74

Chapter Four: Evaluation ...................................................................................................................76

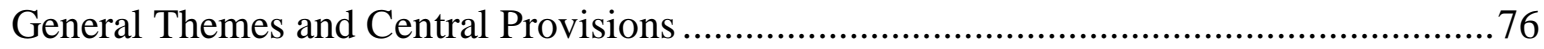

Appropriations

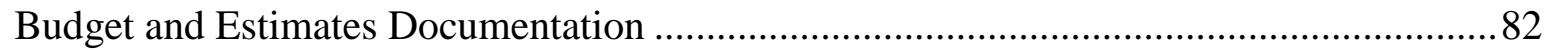

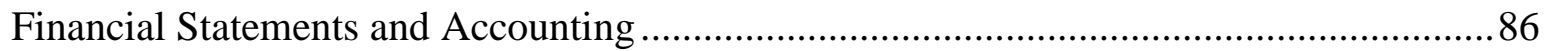

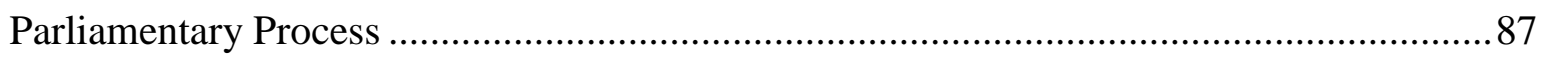

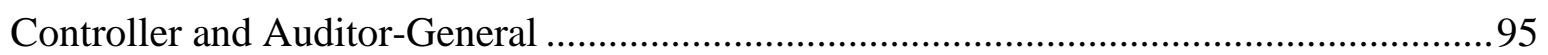

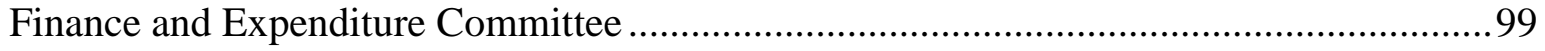

Chapter Five: Recommendations and Conclusion .......................................................109

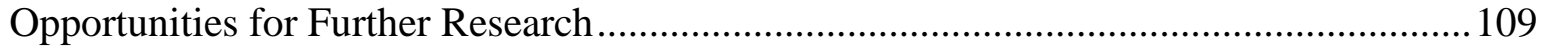

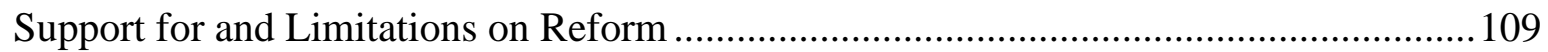

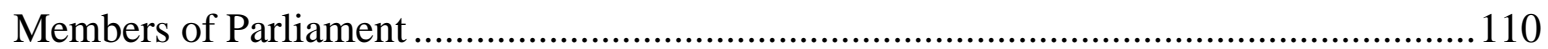




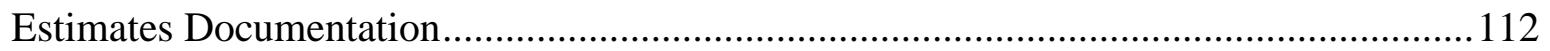

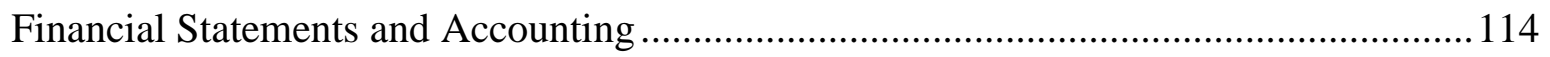

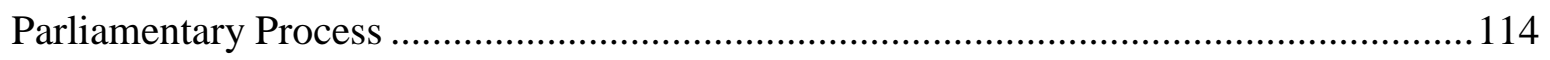

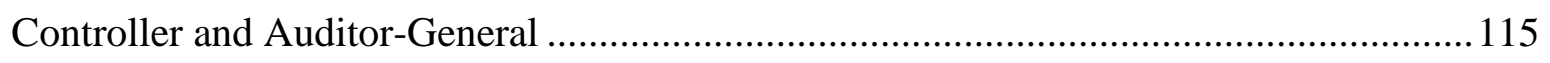

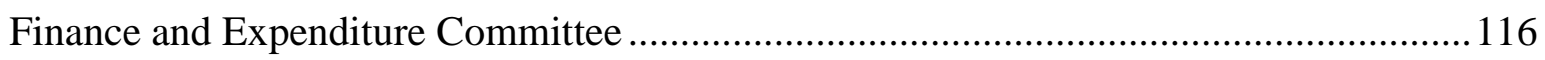

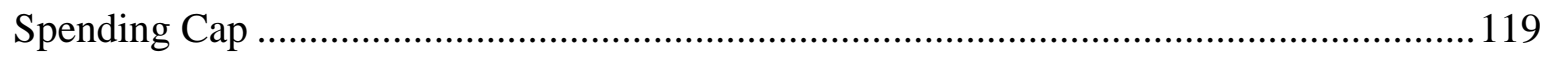

Public Finance Amendment Act 2013 and Public Finance (Fiscal Responsibility)

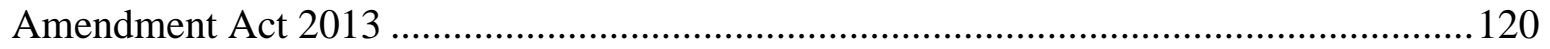

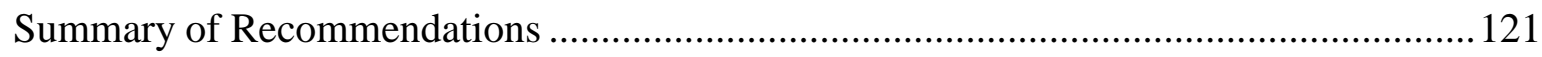

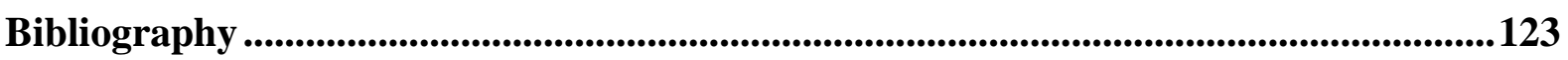




\section{List of Abbreviations and Acronyms}

$\begin{array}{ll}\text { Auditor-General } & \text { Controller and Auditor-General } \\ \text { CEA } & \text { Crown Entities Act 2004 } \\ \text { FEC } & \text { Finance and Expenditure Committee } \\ \text { FPP } & \text { First Past the Post } \\ \text { FRA } & \text { Fiscal Responsibility Act 1994 } \\ \text { GAAP } & \text { Generally accepted accounting practice } \\ \text { House } & \text { House of Representatives of New Zealand } \\ \text { IFRS } & \text { International financial reporting standards } \\ \text { MMP } & \text { Mixed Member Proportional } \\ \text { MP } & \text { Member of Parliament } \\ \text { Member } & \text { Member of Parliament } \\ \text { PAA } & \text { Public Audit Act 2001 } \\ \text { PAC } & \text { Public Accounts Committee } \\ \text { PEC } & \text { Public Expenditure Committee } \\ \text { PFA } & \text { Public Finance Act 1989 } \\ \text { PFA 1989 } & \text { Public Finance Act 1989 } \\ \text { PFA 1977 } & \text { Public Finance Act 1977 } \\ \text { S. } & \text { Section } \\ \text { S.O. } & \text { Standing Orders of the House of Representatives } \\ \text { Standing Orders } & \text { Standing Orders of the House of Representatives } \\ \text { SOE } & \text { State enterprise } \\ \text { Speaker } & \text { Speaker of the House of Representatives } \\ \end{array}$




\section{List of Figures and Tables}

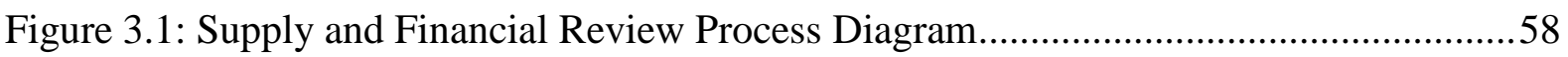

Table 3.1: House Debate Time Limits and MPs Speaking Times

69 


\section{Introduction}

The finance of the country is ultimately associated with the liberties of the country. It is the powerful leverage by which English liberty has been gradually acquired...If the House of Commons by any possibility lose the power of the control of the grants of public money, depend upon it, your liberty will be worth very little in comparison. ${ }^{1}$

William Ewart Gladstone

\section{The Thesis}

The New Zealand Parliament has the important role of controlling and scrutinising the government's expenditure. The government in providing governance for society expends public money that has been earned by the people on their behalf for their benefit. It is fundamental to democracy that the government be held accountable for its expenditure. Parliament, an assembly of representatives, is the body charged with undertaking that task on the people's behalf. It is important that Parliament performs the duty to a high standard given the inherent faith and trust afforded to it by the people. Parliament performs the role by controlling and scrutinising government expenditure. Chubb, in discussing the British House of Commons, effectively defines what is meant by parliamentary scrutiny and control:

It is concerned, first, with questions of policy - what shall be the amount of taxation and expenditure and to what objects public money shall be applied. This policy aspect is the more spectacular, but to view the House only as 'the grand forum of debate', or as a legislative production live, is to miss the other important, though less exciting, aspects of its work. For it is concerned, second, to ensure that the policy which, though it is the government's in origin, it endorses and makes its own, shall be carried out accurately, faithfully, and efficiently. ${ }^{2}$

Therefore, the question is: how effectively does the New Zealand Parliament perform the role of controlling and scrutinising government expenditure? This thesis argues that they perform the role less than optimally. Specifically, it determines that Parliament has adequate control of government expenditure but is somewhat deficient at scrutinising it.

\section{Methodology}

This thesis utilises both primary and secondary sources to determine the effectiveness of Parliament at controlling and scrutinising government expenditure. Although secondary

\footnotetext{
${ }^{1}$ Peter Einzig, The Control of the Purse: progress and decline of Parliament's financial control (London: Secker \& Warburg, 1959), p. 3.

${ }^{2}$ Basil Chubb, The Control of Public Expenditure: Financial Committees of the House of Commons (Oxford: Clarendon Press, 1952), p. 3.
} 
sources particularly academic literature provide a solid foundation for this research it is primary material obtained through interviews that facilitate the answering of the research question. Interviews with key actors, especially Members of Parliament, offered the most potential to effectively analyse and critique Parliament's performance.

There were twelve subjects in total interviewed for this thesis including nine MPs. The composition of the MPs interviewed was as follows: four members of the major government party, one member of a government support party, three members of the major opposition party and one member of a minor opposition party. The MPs had varying levels of parliamentary experience with five having served as a Minister. There was an emphasis on interviewing MPs who were, or had been on, the Finance and Expenditure Committee. Emphasis was placed on interviewing these MPs due to their greater awareness of the function having served at the centre of Parliament's undertaking of it. Two staff members of the Office of the Auditor-General were interviewed. One staff member of the Office of the Clerk was interviewed but was not at liberty to provide opinion and could only provide information. In addition, one public servant from the Treasury provided information at an informal meeting. Further information was subsequently provided by another public servant from the Treasury through e-mail.

All interviews were confidential, information and opinions obtained are not attributed to their source. Confidentiality was provided to participants to ensure that they were open, frank and upfront. However, where it is beneficial the distinction is made between government and opposition MPs and if a member is notably senior in experience. The interview period began in October 2012 and went through to the end of January 2013. All interviews with MPs were undertaken at Parliament Buildings in Wellington. Staff from the Office of the Auditor-General and Office of the Clerk were interviewed at facilities at their respective offices in Wellington. The informal meeting with the public servant from the Treasury was at a café on the Terrace.

\section{Thesis Outline}

The first chapter is a literature review that examines the existing research in the field. The literature review is in two sections. The first section identifies the roles of the New Zealand Parliament including that of controlling and scrutinising government expenditure. The review ascertains that there is an on-going debate on the effectiveness of Parliament at performing the function. As such the thesis is placed into the existing literature on New Zealand's Parliament and its performance of its duties. The second section summarises further literature 
on Parliament's undertaking of the function. These texts examine the function specifically or address particular aspects of it. The chapter determines that: the New Zealand Parliament is recognised as having the role of controlling and scrutinising government expenditure, that there is an on-going debate as how effective Parliament is at undertaking the role and that its current performance requires re-evaluation.

The history of Parliament's control and scrutiny of government expenditure function in both Britain and New Zealand is discussed in the second chapter. The first section describes the origins of the role in Britain. It states how the House of Commons came to hold responsibility for controlling government expenditure and the system comprised of key features, the circle of control, which it subsequently developed to enable it to adequately do so. The second section examines how the New Zealand Parliament took the role as well as practice and procedure inherited from Britain and subsequently developed and refined it. The chapter raises a number of issues and trends for consideration when Parliament's current performance is evaluated. The history of the function further emphasises its importance to Parliament.

Chapter three describes Parliament's current practice and procedure for controlling and scrutinising government expenditure. The first section of the chapter describes the central provisions that allow Parliament to control and scrutinise government expenditure, principally that the Crown requires parliamentary consent in order to spend public money. The chapter subsequently describes the six core components of Parliament's practice and procedure that it currently utilises to perform the function: the appropriations system, Budget and Estimates documentation, financial statements and accounting, the parliamentary process comprising the supply and financial review processes, the Controller and Auditor-General, and the Finance and Expenditure Committee.

The next chapter assesses Parliament's effectiveness at performing the function. The evaluation chapter starts with MPs identifying and defining their understanding of Parliament's role of controlling and scrutinising government expenditure and their overall assessment of Parliament's performance. MPs also comment on what they believe should happen if supply were not granted by Parliament and what affect, if any, the move to the MMP electoral system has had on Parliament's performance of the function. The chapter subsequently evaluates the various components of Parliament's practice and procedure detailed in the previous chapter utilising the material acquired through the interviews and further literature. As such the chapter determines how effective Parliament is at controlling 
and scrutinising government expenditure and identifies where the strengths and weaknesses are in its performance of the function.

The final chapter concludes the thesis with a series of recommendations that have the potential and Parliament should consider implementing in order to improve its control and scrutiny of government expenditure. The chapter considers a range of proposed reforms sourced from the existing literature, the previous history and evaluation chapters, and from the interviewees. 


\section{Chapter One: Literature Review}

\section{Introduction}

Parliamentary control and scrutiny of government expenditure has been written about extensively. As a result this literature review is not exhaustive of all texts in the field. Instead it seeks to give a broad overview of what has been written. The first section of this chapter places the topic of parliamentary control of government expenditure into the broader literature on Parliament, specifically that which discusses the role and functions of Parliament. It establishes that an important function of Parliament is the control and scrutiny of government expenditure, and the extent to which the New Zealand Parliament fulfils the function has been debated over many decades. It is important to note that the prominent academics discussed in the first section wrote over fifty years apart. Some key aspects have changed, and will be described in the next chapter. In order to preserve the purity of the academics' arguments, subsequent changes to Parliament's procedures have been left aside. The second section of this review examines texts that focus more exclusively on Parliament's control and scrutiny of government expenditure, and texts that only cover particular aspects. The second section shows that there are gaps in the literature and gives further evidence that there is a debate as to how well Parliament performs its control and scrutiny function. In summary, this literature review will show that an important function of Parliament is the control and scrutiny of government expenditure; that there is a debate as to how well Parliament performs the function; and that there are gaps in the literature, which I shall aim to fill.

\section{Historical Debate}

McGee describes the theoretical roles and functions of Parliament. Despite identifying that a function of Parliament is the control and scrutiny of government expenditure McGee does not make a judgment as to how effective Parliament is in the role. However, he does go so far as to say that the 'control of public finance has historically been at the heart of Parliament's constitutional pre-eminence'. ${ }^{3}$ McGee provides the most recent extensive description of the institutions and processes that Parliament has available to exert control over government expenditure. ${ }^{4}$

\footnotetext{
${ }^{3}$ David McGee, Parliamentary Practice in New Zealand, Third Edition, (Wellington: Dunmore Publishing, 2005), p. 443.

${ }^{4}$ ibid, pp. 443-516.
} 
McGee makes two important points about the roles and functions of Parliament. Firstly, McGee makes a distinction between Parliament and the House of Representatives. ${ }^{5}$ The New Zealand Parliament contains the House of Representatives and the Sovereign of Right in New Zealand. In other words, the House of Representatives is the elected component of Parliament. ${ }^{6}$ However, the House of Representatives is more commonly known as Parliament, not just as a component of Parliament. Secondly, McGee identifies that the role of the House is not defined anywhere. In fact the functions of the House have largely been determined by its own members. Furthermore, the House does not have an exclusive hold on its functions. ${ }^{7}$

McGee, in differentiating between Parliament and the House, establishes that the two have different sets of functions. McGee states that Parliament only has one function, to make laws. ${ }^{8}$ The House, on the other hand, has four major functions: to serve as a legislature, to provide a government, to scrutinise and control the government and to represent government and the people. ${ }^{9}$ McGee in discussing the scrutiny and control of government function of the House explains that the government requires the continued support of the House for it to stay in office. ${ }^{10}$ The government in exchange for continued support from the House must be answerable for the management of the state. McGee argues that one of the main ways that the House performs the scrutiny and control function is through the annual process of granting supply to the government. ${ }^{11}$ Therefore, McGee identifies that control and scrutiny of government is a primary function of Parliament and that the main method that it uses to achieve this is through the approving of government expenditure.

Palmer and Palmer also identify that a main function of Parliament is the control and scrutiny of government expenditure. Palmer and Palmer provide a concise overview of the procedures and institutions that Parliament has to help it carry out its control of government expenditure function. ${ }^{12}$ They do not comment on how effective Parliament is in this role. However, Palmer in an earlier text commented that the processes of Parliament have historically been insufficient, but believed that there were signs that this was changing. ${ }^{13}$

\footnotetext{
${ }^{5}$ ibid, pp. 1-2.

6 ibid, p. 1.

7 ibid, p. 2.

8 ibid.

${ }^{9}$ ibid, pp.2-5.

10 ibid, p. 4.

11 ibid.

${ }^{12}$ Geoffrey Palmer and Matthew Palmer, Bridled Power: New Zealand's Constitution and Government, Fourth Edition, (Auckland: Oxford University Press, 2004), pp. 118-135.

${ }^{13}$ Geoffrey Palmer, New Zealand's Constitution in Crisis (Dunedin: John McIndoe, 1992), pp. 125- 126.
} 
Palmer and Palmer establish that Parliament is pre-eminent and as a result should be capable of controlling the executive. Palmer and Palmer argue that 'one of the primary constitutional doctrines of the Westminster system of Parliament is parliamentary sovereignty or parliamentary supremacy'. ${ }^{14}$ From there Palmer and Palmer link parliamentary supremacy with Parliament's control of the executive which they argue is a distinguishing feature of parliamentary government. ${ }^{15}$ Palmer and Palmer, with assistance from Rush, explain that parliamentary government is when the membership of the executive comes from the legislature and the executive is answerable to the legislature. ${ }^{16}$ As a result of these various aspects of the Westminster system of parliamentary government Parliament 'has the ability to curb the executive'. ${ }^{17}$ Palmer and Palmer have identified that Parliament should have the ability, in theory at least, to control the executive.

Palmer and Palmer identify that a function of Parliament is to control and scrutinise government expenditure. They list Parliament as having five functions:

- $\quad$ 'Raise the money by which the business of government may be conducted and to approve the expenditure of money

- Consider and pass bills into law

- Provide a place for the airing of grievances

- As a check on the manner in which government is actually carried out

- Serve as a forum for party political contest'. ${ }^{18}$

The first function of Parliament identified by Palmer and Palmer is akin to that of controlling and scrutinising government expenditure. This is particularly the case when it is combined with the fourth function of acting as a check on government. Added to this, Palmer and Palmer believe that 'the power of Parliament over finance is a key element in our system of government'. ${ }^{19}$ Palmer and Palmer, therefore, identify that control and scrutiny of government expenditure is a primary function of the New Zealand Parliament, they just do not judge how effective Parliament is at performing that function.

Jackson takes an alternative approach to the other academics in describing the roles of Parliament. He describes what the roles are in theory before describing what functions

\footnotetext{
${ }^{14}$ Palmer and Palmer, Bridled Power, p. 156.

15 ibid, p. 157.

16 ibid.

17 ibid, p. 158.

18 ibid.

19 ibid, p. 118.
} 
Parliament actually performs. Jackson broadly describes the theoretical roles of Parliament as being:

On the credit side, Parliament may be expected to serve as an information source, a sounding board and safety valve for grievances, while at the same time bestowing an air of authority or legitimacy upon government actions. On the debt side, Parliament means that a government has to give reasons for its actions, debate them and even modify them. In short it must be accountable. ${ }^{20}$

The above description from Jackson is very general when compared to the list approach used by the other academics. In actuality, Jackson does go into greater detail about what the functions of Parliament are and dismisses the general consensus created by other academics. $^{21}$ Unfortunately, Jackson primarily chooses to examine British literature. Although helpful it was not entirely necessary due to the growing amount of New Zealand literature that was available even then.

Jackson, through criticising the roles and functions of Parliament, set out by others, establishes that in theory Parliament controls government finance when in reality he believes it does not. In general, Jackson believes that the New Zealand Parliament has lost most, if not all, of its control functions and has instead become more of a support institution. ${ }^{22}$ Jackson leaves Parliament with only one unquestionable function, that of legitimation. ${ }^{23}$ Jackson states that 'control by an elected body over revenue and expenditure is a myth'. ${ }^{24}$ However, Jackson later softens his view saying:

Overall in the narrow sense of financial accountability, regulatory and propriety in the use of public funds, New Zealand is adequately served by the existing control mechanisms. If, however, one looks at such concepts as value for money or control of the scale of public expenditure and the priorities within it, the same conditions can hardly apply. ${ }^{25}$

In other words, Jackson is arguing that the control of government expenditure is adequate but the scrutiny of that expenditure is inadequate.

Scott is the most straight forward academic when it comes to both describing the roles and functions of Parliament, and offering his opinion on the effectiveness of Parliament's control and scrutiny of government expenditure. Scott argues that the functions of Parliament are: 'legislation (including control of finance); provision of a government; debate; ventilation of grievances; and selection of national leaders' ${ }^{26}$ From a political standpoint the first two

\footnotetext{
${ }^{20}$ Keith Jackson, The Dilemma of Parliament (Wellington: Allen and Unwin, 1987), p. 27.

21 ibid, pp. 37-39.

22 ibid, p. 39.

23 ibid, p. 42.

24 ibid, p. 37.

25 ibid, p. 160.

${ }^{26}$ K.J. Scott, The New Zealand Constitution (London: Oxford University Press, 1962), p. 39.
} 
functions are only seen as functions in a nominal sense. ${ }^{27}$ The legislation function is seen just to be giving effect to the government's proposals, and government changes are linked to the electorate at a general election. Constitutionally, however, Scott believes that the first two functions are the most important, notably including control of government finance. ${ }^{28}$

Scott discusses further the control of finance function of Parliament. Scott believes that Parliament only has control of finance in theory and that real control over financial matters is exercised by the executive. ${ }^{29}$ Scott's argument has two parts. The first is that the House may only consider expenditure proposals from the executive. ${ }^{30}$ Secondly, the House rarely seeks to modify any of the expenditure proposals brought before it. ${ }^{31}$ In summary, Scott identifies that it is a role of Parliament to control government finance but in reality it does not perform that function; control is really with the executive.

Lipson's approach is to identify what the historical functions of Parliament have been. Lipson states that:

At one time or another in their history Parliaments have been called upon to perform functions as vital as the petitioning for remedy of grievances, the authorization of taxation and expenditure, the enactment of laws, the control of executive departments, and the interpretation of public opinion. ${ }^{32}$

Lipson has identified that Parliament is charged with authorising expenditure. Lipson does not go so far as to say that a function of Parliament is to control and scrutinise government expenditure. However, if the authorising function is combined with that of controlling government departments it is possible to see that such a function is within Lipson's role description.

Lipson believes that the ability of Parliament to perform the authorising function has declined. In discussing the ability of Parliament to control government finance Lipson argues that 'Parliament has little say in determining financial policy in the preparatory stages. It has virtually lost control of the public purse' ${ }^{33}$ Added to this, Lipson states:

Control over finance is a co-operative venture jointly managed by the Treasury, the spending departments, the Cabinet, the House of Representatives, and the Controller and Auditor-General. Of all these authorities, the House, though formally supreme, is in actual practice a minor partner. ${ }^{34}$

\footnotetext{
27 ibid.

28 ibid.

29 ibid, p. 56.

30 ibid, p. 57.

31 ibid.

${ }^{32}$ Leslie Lipson, The Politics of Equality: New Zealand's Adventures in Equality (Chicago: The University of Chicago Press, 1948), p. 314.

33 ibid, p. 327.

34 ibid, p. 322.
} 
It is argued that Parliament's ability to perform its functions has declined because it lacks adequate machinery. ${ }^{35}$ Lipson states as much:

to realise that Parliament's various functions are no longer equally suited to its machinery, and that the relative need of legislative participation in these diverse functions has altered, is the key to an understanding of the problem. ${ }^{36}$

Lipson here is arguing that Parliament's institution and processes do not allow Parliament to adequately perform its functions. As stated earlier, much has changed with Parliament's procedures and as a result this may no longer be the case.

\section{Further Literature}

To build a complete picture of the existing literature it is necessary to discuss the texts that have examined more specifically the parliamentary function of controlling and scrutinising government expenditure and those that have covered particular aspects of it. This section will start by addressing the considerable body of literature from the 1950s through to the 1970s when the subject matter was of great interest particularly due to the new Public Expenditure Committee (PEC) and the growing level of government expenditure. The following section also examines the body of literature related to the Public Finance Act 1989 (PFA 1989) and the Fiscal Responsibility Act 1994 (FRA) that fails to adequately address the impact these have had on Parliament. Finally, there will be an examination of the most recent texts including those dealing with MMP and the Finance and Expenditure Committee (FEC). Analysing these texts will reinforce the need identified in the previous section to re-examine how effectively Parliament controls and scrutinises government expenditure and will also determine the approach and focus of this thesis going forward.

\section{0s to 1980s Examinations of Parliamentary Control and Scrutiny}

Extensive literature has been produced on the New Zealand Parliament's control and scrutiny of government expenditure from the 1950s. Both Lipson and Polaschek discussed the function in their works examining politics and public administration in New Zealand. ${ }^{37}$ They did not discuss the function in as much detail as Beck, Downey, Hayes and Wood who focused more specifically on the subject. ${ }^{38}$ Their thesis examined the control of government

\footnotetext{
35 ibid, p. 315.

36 ibid.

37 ibid, pp. 322-327; R.J. Polaschek, Government Administration in New Zealand (London: Oxford University Press, 1958), pp. 240-257.

38 A.J. Beck, L.J. Downey, K. Hayes, and G.E. Wood, The Control of Government Expenditure in New Zealand (School of Public Administration, Victoria University of Wellington, 1962).
} 
expenditure by the government itself and by Parliament. However, the authors note that their thesis focuses only on particular areas. ${ }^{39}$ A slightly later text by Egan, Wakelin and Yuill would be more thorough in its examination.

The thesis produced by Egan, Wakelin and Yuill delivers a very comprehensive assessment of the New Zealand Parliament and the control of government expenditure. ${ }^{40}$ The status of their work is such that it is referred to frequently in later texts including by the Treasury. ${ }^{41}$ The approach taken by Egan, Wakelin and Yuill is very effective and has had a considerable influence on the structure of this thesis. The text concisely summarises the history of parliamentary control of government expenditure and the procedure and practice used by Parliament at that point in time. Egan, Wakelin and Yuill thoroughly assess the procedure and practice that they have described, and from that they produce a number of recommendations for improvements. Through their comprehensive examination they come to the conclusion that parliamentary control of government expenditure is 'imperfect' ${ }^{42}$ Later texts focused on particular aspects of parliamentary control and scrutiny of government expenditure but those that did address the function more broadly were not as comprehensive.

Following Egan, Wakelin and Yuill, further literature was produced that addressed Parliament's control and scrutiny of government expenditure. Shand considers the extent that Parliament controls government expenditure and makes recommendations as to how it could be improved. ${ }^{43}$ Shand, though, is little more than a summary of the work of Egan, Wakelin and Yuill with a greater emphasis placed on potential improvements. McRobie writing in the late 1970s made a fresh examination of the topic and was particularly scathing of parliamentary control. ${ }^{44}$ McRobie does not get tied down in describing practice and procedure instead focusing on determining how effective it is and how effectively it is used. In addition, McRobie, von Tunzelmann and Aitken produced texts examining the PEC, while Leo examines the Auditor-General as well. ${ }^{45}$ These texts vary in focus and approach. For

\footnotetext{
39 ibid, p. 1.

${ }^{40}$ J.P. Egan, H.J. Wakelin, and J. Yuill, Parliamentary Control of Public Expenditure in New Zealand (Diploma of Public Administration, Victoria University of Wellington, 1968).

${ }^{41}$ The Treasury, The Planning and Control of Government Expenditures: Planning, Programming and Budgeting System (Wellington: Government Printer, 1973), p. 8.

${ }^{42}$ Egan, Wakelin and Yuill, Parliamentary Control, p. 80.

${ }^{43}$ D.A. Shand, 'Parliamentary Control of the Public Purse- How Real', Journal of Public Administration, Vol. 34, No.2 (March 1972), pp. 59-73.

${ }^{44}$ Alan McRobie, 'Parliamentary 'Control' of Public Expenditure', in Stephen Levine (ed.), Politics in New Zealand: A Reader (Sydney: George Allen \& Unwin, 1978), pp. 115-130.

${ }^{45}$ Alan McRobie, 'The New Zealand Public Expenditure Committee', Political Science, Vol. 26, No. 1 (1974), pp. 28-46; Adrienne von Tunzelmann, The Public Expenditure Committee: The Process of Change 1962-1977 (M.P.P, Victoria University of Wellington, 1977); Judith Aitken, Public Expenditure Planning in New Zealand (Ph.D., Victoria University of Wellington, 1983), pp. 597-689; Ann Puat Leo, The Role of the Public
} 
example von Tunzelmann uses a chronological approach to track changes made to the committee and their impact. Therefore, the literature on Parliament's control and scrutiny of government expenditure is quite rich through to the 1980s. There has since been a considerable decline with subsequent texts mostly concentrating on certain elements of parliamentary control and scrutiny.

\section{Finance and Expenditure Committee}

Thorough comparative research has been undertaken into Public Accounts Committees (PACs), including New Zealand's FEC, the literature does not examine the effectiveness of the latter committee. Comprehensive studies have been undertaken to determine key features and to establish what makes for an effective PAC. ${ }^{46}$ McGee considers PACs extensively in his work while also examining broader issues relating to Parliaments and the Budget process. ${ }^{47}$ These studies do not specifically address New Zealand's FEC. KPMG carried out a comparative study of PACs in Australasia including the FEC and the committees at the state/territory level. ${ }^{48}$ The comparative approach is used to identify 'the range of structures, responsibilities and working practices' across the various PACs. ${ }^{49}$ The study serves as an excellent source of information about the committees but they do not attempt to judge the effectiveness of their work. Jacobs, Jones and Smith who reported on the findings of the survey suggest this should be a future line of research. ${ }^{50}$ Therefore, it would be appropriate to consider the effectiveness of the FEC with the guidance of the criteria offered by the existing literature.

\section{Legislation Changes}

The introduction of the PFA 1989 and the FRA had a considerable impact on Parliament's control and scrutiny of government expenditure with a body of literature reflecting this. Ball

\footnotetext{
Expenditure Committee and the Audit Office in the Policy Making and Administrative System in New Zealand (Masters of Public Policy Research Paper, Victoria University of Wellington, 1978).

${ }^{46}$ David McGee, The Overseers: Public Accounts Committees and Public Spending (London: Pluto Press, 2002); Riccardo Pelizzo, Rick Stapenhurst, Vinod Sahgal and William Woodley, 'What Makes Public Accounts Committees Work? A Comparative Analysis', Politics \& Policy, Vol. 34, No. 4 (2006), pp. 774-793; Riccardo Pelizzo and Rick Stapenhurst, 'Strengthening Public Accounts Committees by Targeting Regional and Country Specific Weakness', in Anwar Shah (ed.), Performance, Accountability and Countering Corruption (Washington DC: World Bank Institute, 2007), pp. 379-393.

${ }^{47}$ David McGee, The Budget Process: A Parliamentary Imperative (London: Pluto Press, 2007).

${ }^{48}$ KPMG, The Parliamentary Public Accounts Committee: An Australian and New Zealand Perspective (Canberra: KPMG, 2006).

49 ibid, p. 2.

${ }^{50}$ Kerry Jacobs, Kate Jones and David Smith, 'Public Accounts Committees in Australasia: The state of play', Australasian Parliamentary Review, Vol. 22, No. 1 (autumn 2007), p. 43.
} 
explains the changes to accounting and accountability that resulted from the PFA 1989 and, in particular, how they would impact upon the Controller and Auditor-General. ${ }^{51}$ However, Ball does not consider more broadly how the changes will affect parliamentary control. Pallot has also examined the impact of the PFA 1989 in her work. Pallot when examining the changes discusses more broadly the impact of the PFA 1989 on Parliament, ${ }^{52}$ including a piece that examines the Auditor-General. ${ }^{53}$ The FRA has been discussed extensively in the literature by the likes of Scott, Wilkinson and Janssen. ${ }^{54}$ The effect the legislation has had on Parliament was not considered by these authors. Pallot and Newberry have considered the impact of the PFA 1989 on Parliament as well as the potential impact of the Public Finance Amendment Bill 2004. ${ }^{55}$ They also examined further issues relating to Parliament and government including expenditure, to a limited extent, and were of the opinion that 'Parliament's ability to scrutinise and control Crown financial activities has been severely eroded, and requires reinstating, ${ }^{56}$ Consequently, the impact that the FRA has had on Parliament should be examined, and the effect of the PFA 1989 should be re-examined due principally to the passage of time and further proposed changes.

\section{Impact of MMP}

New Zealand's adoption of the MMP electoral system created a small burst of literature that focused on issues around Parliament and government expenditure. James, writing at the time of MMP's introduction, explains how there were both concerns and optimism about the effect that MMP would have on the Budget. In particular there were concerns from participants at a forum discussing the potential impact of MMP about what impact the new electoral system

\footnotetext{
${ }^{51}$ Ian Ball, 'Changes in Accounting and Auditing Practices: The New Zealand Experience', in John Foster and John Wanna (eds.), Budgetary Management and Control: The Public Sector in Australasia (Melbourne: Macmillan Australia, 1990), pp. 128-141.

${ }^{52}$ June Pallot, 'Financial Management Reform', in Susan Newberry (ed.), The Legacy of June Pallot: Public Sector Financial Management Reform (Greenwich: Information Age Publishing, 2006), pp. 25-54; June Pallot, 'Accounting, Auditing, and Accountability', in Susan Newberry (ed.), Legacy of June Pallot, pp. 55-87; June Pallot, 'New Public Management Reform in New Zealand: The Collective Strategy Phase', in Susan Newberry (ed.), the Legacy of June Pallot, pp. 219-239.

${ }^{53}$ June Pallot, 'A Wider Accountability? The Audit Office and New Zealand's Bureaucratic Revolution', in Susan Newberry (ed.), the Legacy of June Pallot, pp. 261-289.

${ }^{54}$ Graham Scott, 'New Zealand's Fiscal Responsibility Act', Agenda, Vol. 2, No. 1 (1995), pp. 3-16; Bryce Wilkinson, 'Restraining Leviathan: A Review of the Fiscal Responsibility Act 1994', November 2004, http://www.treasury.govt.nz/downloads/pdfs/tfr-rl-1nov09.pdf (18 July 2012); John Janssen, 'New Zealand's Fiscal Policy Framework: Experience and Evolution', December 2001, http://www.treasury.govt.nz/publications/research-policy/wp/2001/01-25/twp01-25.pdf (18 July 2012).

${ }^{55}$ Susan Newberry and June Pallot, 'A Wolf in Sheep's Clothing? Wider Consequences of the Financial Management System of the New Zealand Central Government', Financial Management \& Accountability, Vol. 21, No. 3 (August 2005), pp. 263-277.

${ }^{56}$ Newberry and Pallot, 'A Wolf in Sheep's Clothing?', p. 274.
} 
would have on the granting of supply, if any changes would be made to the Budget process, and the effect of the new financial veto procedure. ${ }^{57}$ Dale also examined the impact that MMP could have on the Budget process. Dale, combined with commentary from Pallot, identify a number of issues related to MMP as well as others including the specification of appropriations and the controller function. ${ }^{58}$ Power produced a more extensive work on the financial veto but was only in a position to make predictions about its potential impact. ${ }^{59}$ Boston and Church examine the effect that the adoption of MMP has had on the Budget process. ${ }^{60}$ They argue that the role of Parliament in relation to the Budget has changed little with the move to MMP. However, their analysis is limited to the first few years of MMP and they do not effectively address how procedure and practice, as well as political culture, have been affected. The impact of MMP must be examined more closely.

\section{Conclusion}

The literature on New Zealand Parliament's control and scrutiny of government expenditure shows that there is an on-going debate as to how effective Parliament is at carrying out this function. Across the broader literature that examines the New Zealand Parliament and its functions it is widely accepted that one of Parliament's roles is to control and scrutinise government expenditure. However, those that make a judgement on how well Parliament performs this function are not in agreement. The most authoritative assessment from Jackson is that Parliament has adequate control of government expenditure but does not carry out effective scrutiny. However, this assessment is 25 years old and as is shown in the following chapter there have been considerable changes made since then. So, this thesis will determine how effectively the New Zealand Parliament currently controls and scrutinises government expenditure.

Examination of the literature that addresses the function more specifically, or an aspect of it, reinforces the need to determine how effectively Parliament carries out the function and shows that there are a number of holes in the evidence that should be addressed. Egan, Wakelin and Yuill carried out the most effective examination amongst a large body of

\footnotetext{
${ }^{57}$ Colin James, Under New Sail: MMP and Public Servants (Wellington: Institute of Policy Studies, 1997), pp. 84-88.

58 Tony Dale, 'The Budget Process', in Alan Simpson (ed.), The Constitutional Implications of MMP, Occasional Publication No. 9 School of Political Science and International Relations, (Wellington: Victoria University of Wellington, 1998), pp. 236-253.

${ }^{59}$ Timothy Power, The Financial Veto: Changing the rules of the Game (LLM, Victoria University of Wellington, 1996).

${ }^{60}$ Jonathan Boston and Stephen Church, 'The Budget Process in New Zealand: Has Proportional Representation Made a Difference', Political Science, Vol. 54, No. 2 (2002), pp. 21-43.
} 
literature from the 1950s through to the 1980s. The literature since then has focused on addressing particular aspects of parliamentary control, or in discussing related issues, has not addressed the impact it has had on Parliament. Specifically the effect of the changing legislative framework has not been adequately discussed. Nor has the impact of the move to MMP been adequately addressed. Analysis of the FEC has not determined how well it carries out its work. In summary, this literature review has determined that there is a need to re-assess the New Zealand Parliament's control and scrutiny of government expenditure. 


\section{Chapter Two: History of Parliamentary Control and Scrutiny of Government Expenditure}

\section{Introduction}

To understand the New Zealand Parliament's function of controlling and scrutinising government expenditure today it is necessary to know its origins. New Zealand inherited from Britain the control and scrutiny of government expenditure function when it got its own Parliament in the 1850s. The system that New Zealand inherited had developed in Britain over many centuries. Palmer and Palmer state that:

Money has always been a core concern of the Westminster constitution. A large part of the historical development of constitutional relations between the English Crown and Parliament can be seen as a struggle over who has the power to tax and spend. ${ }^{61}$

It is significant that New Zealand inherited a system of governance where the government has the right to propose expenditure while Parliament has the right to approve it. ${ }^{62}$ The system that only the government could propose expenditure formally dates back to the Standing Orders of the House of Commons of 1713, but in reality, it goes back to the very beginning of the English Parliament. ${ }^{63}$ As shown in this chapter, New Zealand continued to operate this system with slight modification.

The system of control and scrutiny of government expenditure that New Zealand inherited from Britain was advanced for its time. Egan, Wakelin and Yuill set out that the New Zealand Parliament inherited a number of features from the British Parliament that enabled and aided the control and scrutiny of government expenditure. ${ }^{64}$ They provide five clear key features: detailed appropriation, the keeping of adequate accounts, a consolidated fund, a Comptroller and Auditor-General and a Public Accounts Committee (PAC). Britain had all of these features in place by the 1860 s completing the 'circle of control' that allowed the House of Commons to control and scrutinise government expenditure. ${ }^{65}$ The following section summarises the British development of these features.

It should be noted that New Zealand also inherited the House of Commons procedure for dealing with financial business. In particular New Zealand inherited the Committees of

\footnotetext{
${ }^{61}$ Palmer and Palmer, Bridled Power, p. 118.

62 ibid.

${ }^{63}$ Egan, Wakelin and Yuill, Parliamentary Control, p. 34.

64 ibid, p. 13.

${ }^{65}$ Chubb, The Control of Public Expenditure, p. 6.
} 
the Whole House, specifically the Committees of Supply and Ways and Means. ${ }^{66}$ Britain used Committees of the Whole House because they wished to remove the influence of the king in the form of the Speaker while they dealt with financial matters. ${ }^{67}$ The Committee of Supply allowed for the hearing of grievances before the Crown was granted supply. ${ }^{68}$ By the time the New Zealand Parliament was established Britain had a recognisable budgeting process. The process was annual by the 1860s. ${ }^{69}$ Britain had begun budgeting in the last quarter of the $18^{\text {th }}$ century but key components of the process were not in place until $1866 .^{70}$ The term Budget originates from the leather pouch that the king used to carry his money. ${ }^{71}$ New Zealand has subsequently developed and modified these inherited features. Before the development of the five key features is detailed it must be set out how the British Parliament came to control expenditure through its right to consent to taxation.

\section{British History}

\section{Consent to Taxation}

The Magna Carta, first signed in 1215, established the principle that there could be "no taxation without consent'. The Magna Carta set out that taxation could only be levied if it were approved by the 'common counsel'. ${ }^{72}$ The monarch was required to give forty days' notice that he was calling the Common Counsel if he wished to levy taxes. ${ }^{73}$ There was initially resistance to the Magna Carta from the Crown and no taxation without consent was even omitted from some later versions. However, difficulties in collecting taxes later in the century made the Crown realise that common consent was now a necessity. ${ }^{74}$ Edward I in 1295 acknowledged that taxes needed common consent saying that "what touches all must be approved by all' ${ }^{75}$ It was clear that common consent could be given only by an assembly that was representative of the realm. ${ }^{76}$ From the 1260 s Parliament was made up of knights as well

\footnotetext{
${ }^{66}$ Egan, Wakelin and Yuill, Parliamentary Control, pp. 33-34.

67 ibid, p. 34.

${ }^{68}$ Beck, Downey, Hayes and Wood, The Control of Government Expenditure, pp. 8-9.

${ }^{69}$ McGee, The Budget Process, p. 126.

${ }^{70}$ Carolyn Webber and Aaron Wildavsky, A History of Taxation and Expenditure in the Western World (New

York: Simon and Schuster, 1986), p. 327.

71 ibid, p. 176.

72 D.A. Carpenter, 'Origin of the Commons, Magna Carta to 1307', in Robert Smith and John Moore (eds.), The House of Commons: Seven Hundred years of British Tradition (London: Smith's Peerage Limited, 1996), p. 29.

${ }^{73}$ Tom McRae, A Parliament in Crisis: The Decline of Democracy in New Zealand (Wellington: Shieldaig Productions, 1994), pp. 4-5.

${ }^{74}$ Carpenter, 'Origin of the Commons', p. 29.

75 John Moore, 'Introduction', in Smith and Moore (eds.), The House of Commons, p. 7.

${ }^{76}$ Carpenter, 'Origin of the Commons', p. 29.
} 
as leading figures (burgesses) from each of the boroughs. Norton identifies this as the beginning of the House of Commons. ${ }^{77}$ There was now a representative assembly that had consenting to taxation as one of its functions.

Parliament in the centuries that followed only had a limited ability to consent to taxation, but it started to get concessions for giving it. Payling argues that Parliament's right to consent was 'very short of free refusal', because although Parliament had the right to consent through its representative nature, the 'Crown had the right to demand a share of its subject's goods in times of common necessity'. ${ }^{78}$ Carpenter, however, believes that Parliament as early as 1242 refused to consent to taxation and had made demands in return for consenting to taxation. ${ }^{79}$ There is consensus that from the $14^{\text {th }}$ through to the $17^{\text {th }}$ century Parliament developed the ability to refuse to consent and to get redress for supply. In other words, it was able to apply conditions to the giving of consent to taxation. ${ }^{80}$ Parliament could get redress for supply because the Crown had become more dependent on taxation to finance increasingly expensive warfare and its own extravagance. ${ }^{81}$ Parliaments from as early as 1309 , in return for consenting to taxation, had made the king accept public petitions for the redress of grievances. ${ }^{82}$ Furthermore, in 1340 the British Parliament showed the first signs that it wished to check how taxation was used when it got commissioners appointed to audit the accounts of subsidy collectors. ${ }^{83}$

In the $17^{\text {th }}$ century Parliament firmly established its ability to get redress for supply and developed its right to consent to taxation into the right also to approve how it would be spent. The Crown had become even more dependent on taxation consented to by Parliament. ${ }^{84}$ The House of Commons had grown in self-confidence and felt an increasing need to justify grants of taxation to its constituents. ${ }^{85}$ Its ability to get redress for supply grew when James II was removed from the throne by Parliament. Parliament took the opportunity to reaffirm that it had to consent to taxation, and that it must approve how that taxation would be spent, with the passage of the Bill of Rights $1688{ }^{86}$ Article four of the Bill of Rights 1688 states:

\footnotetext{
${ }^{77}$ Phillip Norton, Parliament in British Politics (Basingstoke: Palgrave MacMillan, 2005), p. 16.

${ }^{78}$ Simon Payling, 'The Later Middle Ages', in Smith and Moore (eds.), The House of Commons, p. 51.

${ }^{79}$ Carpenter, 'Origin of the Commons', p. 30.

${ }^{80}$ Moore, 'Introduction', p. 10.

81 ibid, pp. 10-15.

${ }^{82}$ Norton, Parliament in British Politics, p. 17.

83 ibid, p. 18.

${ }^{84}$ ibid.

${ }^{85}$ Payling, 'The Later Middle Ages', p. 52.

${ }^{86}$ Norton, Parliament in British Politics, p. 19.
} 
That levying money for or to the use of the Crowne by pretence of prerogative, without grant of Parlyament, for longer time or in other manner than the same is or shall be granted, is illegal. ${ }^{87}$

McRae argues that the Bill of Rights 1688, particularly when combined with the Magna Carta, sets out that Parliament does not only consent to taxation but it must approve 'the use the executive, using the Crown's name, makes of it' ${ }^{88}$ The Parliament had evolved from giving consent to taxation to also approving how taxation would be spent. Parliament, to an extent, had gained the ability to control and scrutinise government expenditure. However, Parliament would need to develop machinery to make its control of government expenditure effective.

\section{Detailed Appropriation}

The British Parliament had gained control over government expenditure following the revolution and the signing of the Bill of Rights in 1688. There was precedent for Parliament appropriating money for specific purposes. ${ }^{89}$ However, it was not common and was typically only when Parliament was in a strong bargaining position. In 1665 when Parliament supplied the Crown with money for fighting the Dutch, Sir George Downing, a teller at the Exchequer, added 'into the subsidy bill a proviso, that the money raised by virtue of that act should be applicable only to purposes of the war'. ${ }^{90}$ Although there was initially resistance to the move from the Crown the king accepted it. When combined with earlier cases of appropriation in 1624 and 1641 Parliament came to believe that its task was not only to consent to taxation but to approve of how the taxation would be spent. ${ }^{91}$

From 1688 the British Parliament began consistently to approve the appropriations of funds for specific purposes. Furthermore, Parliament from 1688 only granted the monarch enough money to last a year, thus establishing annual control of government expenditure. ${ }^{92}$ In order to appropriate funds it was necessary to present Parliament with Estimates as to what the government wanted to spend. ${ }^{93}$ At first only the military submitted Estimates and they featured little detail. Civil spending, including the expenses of the Crown in the form of the Civil List, was one single complex appropriation. ${ }^{94}$ The 'economic reform' movement in the 1780s led to increased interest in reforming government administration. Reforms, starting

\footnotetext{
${ }^{87}$ McRae, A Parliament in Crisis, p. 10.

88 ibid.

${ }^{89}$ Henry Hallam, The Constitutional History of England (New York: Garland Publishing, 1978), p. 55.

${ }^{90}$ ibid.

91 ibid.

${ }^{92}$ Webber and Wildavsky, A History, p. 286.

${ }^{93}$ Chubb, The Control of Public Expenditure, p. 8.

94 ibid, p. 9.
} 
with the Civil Establishment Act 1782 and concluding with the Exchequer and Audit Departments Act 1866, included gradually reducing the expenditure in the Civil List. It was instead put through Parliament's supply procedures which included more detailed Estimates. ${ }^{95}$ Parliament experimented with the specification of Estimates through to 1847 when they began to resemble their current form. ${ }^{96}$ The British Parliament had 'detailed and rigidly defined' appropriation by $1866 .{ }^{97}$

\section{Government Accounts and Consolidated Fund}

Parliament recognised that detailed appropriation was not sufficient to ensure that money was spent as appropriated. Parliament needed to check that the government spent the money as set out in the appropriations. ${ }^{98}$ By the $19^{\text {th }}$ century it checked government spending in three ways: it ensured that it was presented with accounts that linked money that had been spent with what had been appropriated, by auditing the accounts and by controlling the issuing of money to the government. ${ }^{99}$ Parliament began to take control of the public accounts in the late $18^{\text {th }}$ century. A number of attempts had been made in the past to take control of the government's accounts, but they were generally unsuccessful. ${ }^{100}$ Parliament demanded better public accounts from the 1780s. In 1802 'finance accounts' were presented, with balanced accounts starting in 1822, but it was not until the Exchequer and Audit Departments Act was passed in 1866 that Parliament firmly established control over the government's accounts. ${ }^{101}$

A further key development with the government's accounts was the introduction of the consolidated fund in 1787. With a consolidated fund, all revenue collected goes into a single account. The funds collected in the single consolidated account are then distributed to where Parliament has approved in the appropriations. ${ }^{102}$ Before the introduction of the consolidated fund, items of revenue were allocated to items of expenditure. Egan, Wakelin and Yuill argue that parliamentary control under the previous system was diffused because the tying together of taxation and expenditure in such a way meant that it was not considered rationally. ${ }^{103}$ Expenditure was often judged by what item of revenue it was linked to and not just whether it

\footnotetext{
${ }^{95}$ Egan, Wakelin and Yuill, Parliamentary Control, p. 14.

96 ibid, pp. 14-15.

${ }^{97}$ Chubb, The Control of Public Expenditure, p. 12.

${ }^{98}$ Egan, Wakelin and Yuill, Parliamentary Control, p. 15.

99 ibid.

100 ibid.

101 ibid.

102 ibid.

103 ibid.
} 
was of merit. Furthermore, the introduction of the consolidated fund meant that all government expenditure went through Parliament. ${ }^{104}$

\section{Comptroller and Auditor-General}

The Office of the Comptroller and Auditor-General, with the complementary roles of serving as controller and auditor, developed out of the Exchequer. The Exchequer was England's ancient treasury holding a central role in government through to the $17^{\text {th }}$ century. ${ }^{105}$ From the 1660s the Exchequer was broken up with it losing the treasury role. The Exchequer's responsibilities were limited 'to the receipt, issue, recording and audit of public money'. ${ }^{106}$ The Exchequer was not notably effective at carrying out these tasks. As a result the economic reform movement pushed for change. There was a gradual process of change through to 1834 which resulted in the Exchequer losing more of its functions. It was, however, left with one important role; to ensure that all issues of money to the government were legal (i.e. the controller function). Key features of the later Comptroller and Auditor-General role were also established. The Exchequer carried out the controller function for Parliament rather than the government, and the head of the Exchequer, the Comptroller of the Exchequer, was an independent officer who could not be a member of the House of Commons. ${ }^{107}$

Parliament would establish a stronger auditor by the middle of the $19^{\text {th }}$ century. Britain had a long history of auditing by the $18^{\text {th }}$ century. The Exchequer had carried out audits for the Crown as far back as the $11^{\text {th }}$ century. ${ }^{108}$ Parliament had at various times carried out its own audits, such as with its appointment of commissioners in 1340 to audit the collectors of subsidies, ${ }^{109}$ and in 1666 to audit the public accounts and investigate potential fraud, which it found. ${ }^{110}$ Parliament, however, would not start to develop a sufficient level of auditing until the 1780s. ${ }^{111}$ The economic reform movement was again responsible for the change. From 1780 Commissioners of Audit were appointed replacing the previous Exchequer auditors. ${ }^{112}$ An Audit Board comprised of five members was formed in 1785. The creation of the Audit Board established the precedent that auditors could retain their position provided they showed

\footnotetext{
104 ibid.

105 ibid.

106 ibid, p. 16.

107 ibid.

108 Webber and Wildavsky, A History, pp. 213-214.

${ }^{109}$ Norton, Parliament in British Politics, p. 18.

${ }^{110}$ Hallam, The Constitutional History of England, pp. 56-59.

${ }^{111}$ Egan, Wakelin and Yuill, Parliamentary Control, p. 16.

112 ibid.
} 
'good behaviour'. ${ }^{113}$ However, there were a number of problems with the Audit Board; principally that it could not be recognised as a servant of Parliament. The Audit Board's members were appointed by the government under Parliament's authority, but it had no means of reporting to Parliament or getting its recommendations implemented. The audited accounts were instead sent to the Treasury, rather than Parliament, and due to the poor quality of the accounts its audits were of little use. ${ }^{114}$

The problems with the Audit Board were addressed with the creation of the Office of the Comptroller and Auditor-General. The Exchequer and Audit Departments Act 1866 merged the Exchequer and Audit Board under the leadership of the Comptroller and AuditorGeneral. The Comptroller and Auditor-General retained the good behaviour requirement of the Audit Board and no longer reported to the Treasury. ${ }^{115}$ Chubb states that the Comptroller and Auditor-General 'was to audit the department's accounts for the House of Commons and to report its findings to it. In this way the machinery of audit was finally harnessed to parliamentary control'. ${ }^{116}$ The Comptroller and Auditor-General could now be identified as a servant of Parliament. Furthermore, the Comptroller and Auditor-General benefited from improvements to the government's accounts and the creation of the PAC. ${ }^{117}$

\section{Public Accounts Committee}

A permanent PAC was the final feature the British Parliament created that New Zealand inherited. Egan, Wakelin and Yuill argue that the final requirement for parliamentary control of government expenditure is a permanent committee of the House to review the government's accounts. ${ }^{118}$ While detailed appropriations, proper accounts and a Comptroller and Auditor-General were all important, the information they produced was only useful if it was thoroughly considered. The solution was a PAC. ${ }^{119}$

The British Parliament had a history of creating committees and appointing commissioners to examine taxation and expenditure issues. McGee traces committees as far back as $1341 .^{120}$ The various committees that Parliament created through to the late $18^{\text {th }}$ century were not very effective. They did not have access to much information and their

\footnotetext{
113 ibid.

114 ibid.

115 ibid.

${ }^{116}$ Chubb, The Control of Public Expenditure, p. 20.

117 Egan, Wakelin and Yuill, Parliamentary Control, p. 16.

118 ibid, p. 17.

119 ibid.

${ }^{120}$ McGee, Parliamentary Practice, p. 426.
} 
existence was infrequent and temporary. Committees became more common from the $1780 \mathrm{~s}$ as a result of the other developments outlined. These committees were of limited effectiveness, but they did contribute ideas as to what a permanent committee should look like. ${ }^{121}$

The creation of a permanent PAC was the result of a number of committee and commission investigations. The Royal Commission of 1831 and the Treasury Committee of 1845 both recommended the appointment of a commission, or the creation of a committee of the House of Commons to examine the government's accounts. ${ }^{122}$ Moore adds that the British PAC was based on an earlier Canadian PAC that was established in the 1830s. ${ }^{123}$ The decisive recommendation for the formation of a PAC was that of the 1856 Baring Committee. The Baring Committee made a number of recommendations to improve Parliament's control of government expenditure. ${ }^{124}$ A key recommendation was that the audited accounts should annually be submitted to a committee of the House of Commons that the Speaker would nominate. Although the Baring Committee's report was well received, the implementation of the various proposals took time. ${ }^{125}$ The PAC was finally introduced in $1861 .^{126}$

\section{Conclusion}

The New Zealand Parliament in the 1850s inherited the control and scrutiny of the government expenditure function from the British House of Commons. Specifically New Zealand inherited a system of governance where the government had the right to propose expenditure and Parliament had the right to approve it. As a part of that inheritance New Zealand got a system, the 'circle of control', that comprised a number of key features to support Parliament's ability to carry out the control and scrutiny of government expenditure function. Features included parliamentary procedure, detailed appropriation, government accounts including a consolidated fund, a Controller and Auditor-General (Auditor-General) and a PAC. Not all of the features were fully developed in the 1850 s, such as the PAC and the Auditor-General, but they would be quickly adopted. The following section describes how New Zealand developed on what it inherited from Britain.

\footnotetext{
${ }^{121}$ Egan, Wakelin and Yuill, Parliamentary Control, p. 17.

122 ibid.

${ }^{123}$ Moore, 'Introduction', p. 19.

${ }^{124}$ Chubb, The Control of Public Expenditure, p. 29.

${ }^{125}$ Egan, Wakelin and Yuill, Parliamentary Control, p. 18.

${ }^{126}$ Norton, Parliament in British Politics, p. 121.
} 


\section{New Zealand History}

\section{Introduction}

The following section summarises the major developments in the New Zealand Parliament's practice and procedure for controlling and scrutinising government expenditure. This section does not cover every single development. It instead summarises the major developments and trends with a particular focus on issues relevant to the later chapter that evaluates how Parliament currently controls and scrutinises government expenditure. This section is structured in much the same way as the previous one that dealt with British developments. However, there is a more extensive examination of the development of parliamentary process, and an additional section that describes the recent developments related to Parliament's ability to scrutinise the government's economic and fiscal policy at a high level including government expenditure.

\section{Appropriations}

The New Zealand Parliament has always been presented with detailed appropriations but the level of detail has been reduced in the past to make them more digestible for MPs. The appropriations presented to Parliament through to the 1940s were extremely detailed with New Zealand labelled as having 'an addiction to detail'. ${ }^{127}$ From the early 1940s the level of detail in the Estimates was gradually decreased reducing the size of the Estimates document. Furthermore, in 1968 items of expenditure were rounded to the nearest $\$ 1000$ and items smaller than $\$ 1000$ were either merged with other items or removed altogether. Egan, Wakelin and Yuill provide that the changes introduced, although resulting in reduced detail, actually benefitted parliamentary control because they were more appropriate for Parliament. ${ }^{128}$ Initially Parliament did not appropriate money to government on a strictly annual basis. That would not begin until 1865. ${ }^{29}$

There has been a steady increase in the information contained and provided with the Estimates. Initially the Estimates presented to the House only showed what the government wanted to spend in the coming year. ${ }^{130}$ If an MP wanted to make a comparison with the previous year they had to use the separate statement of expenditure. The statement of expenditure did not show the appropriation the previous year's spending had been made

\footnotetext{
${ }^{127}$ Egan, Wakelin and Yuill, Parliamentary Control, p. 18.

128 ibid, p. 20.

${ }^{129}$ David McGee, Parliamentary Practice in New Zealand (Wellington: Government Printer, 1985), p. 302.

${ }^{130}$ Egan, Wakelin and Yuill, Parliamentary Control, p. 19.
} 
against; an MP would need a copy of the previous year's Estimates to do that. The presentation of appropriated accounts from 1862/63 that showed the appropriation, what was actually spent, and the difference between the two helped. However, the appropriated accounts were not as detailed as the Estimates. The Estimates resembling their current form first appeared in 1939/40. They now showed for each item of expenditure the amount requested for the coming year as well as the amounts requested and actually spent in the previous year. The new format was seen to improve parliamentary control as it facilitated closer scrutiny. ${ }^{131}$ The level of information presented with the Estimates was increased with the Public Finance Act 1989 (PFA 1989). ${ }^{132}$

Before the PFA 1989 Parliament appropriated funds to the government on the cash cost of inputs. Each department had a Vote that contained a number of inputs. Inputs were the cash requested by the government for departments organised under standard expenditure groups such as personnel, capital expenditure and maintenance. Program budgeting had been introduced in the late 1960s and early 1970s. It sought to organise inputs into broad programmes. It had been hoped that programme budgeting would turn the focus of politicians from the annual consideration of inputs to long term government objectives. ${ }^{133}$ Programme budgeting failed to take off with programmes poorly defined or simply acknowledged department's organisational units. ${ }^{134}$ Departments were reluctant to use it and most politicians did not understand it which created the real problem; a lack of political support. ${ }^{135}$ Furthermore, the system of inputs and program budgeting was deeply flawed. ${ }^{136}$

The PFA 1989 completely overhauled appropriations. Three new types of appropriations were introduced: outputs for the purchase of goods and services, for capital investment and for the payment of benefits and grants. ${ }^{137}$ Output class, containing a common set of outputs, was the level at which Parliament authorised the purchase of outputs in the appropriation process. ${ }^{138}$ The Public Finance Amendment Act 2004 allowed for the merger of

\footnotetext{
131 ibid.

132 The Treasury, 'Putting it Simply: an Explanatory Guide to Financial Management Reform', January 1989, http://www.treasury.govt.nz/publications/guidance/publicfinance/pis/ (20 July 2012), pp. 21-22.

${ }_{133}$ Pallot, 'Financial Management Reform', p. 27; Ball, 'Changes in Accounting and Auditing Practices', p. 134. 134 ibid, pp. 133-134.

135 Geoff Skene, 'Auditing, Efficiency and Management in the New Zealand Public Sector', Australian Journal of Public Administration, Vol. 44, No. 3 (September 1985), p. 276.

${ }^{136}$ Pallot, 'Financial Management Reform', pp. 28-29.

137 Jonathan Boston, 'Financial Management Reform: Principles and Practice in New Zealand', Public Policy and Administration, Vol. 8, No. 1 (1993), p. 17, Treasury, 'Putting it Simply', pp. 18-19.

138 Treasury, 'Putting it Simply', p. 11.
} 
several output classes into one appropriation, a multi-class output appropriation. ${ }^{139}$ Separate appropriation types for buying outputs and capital investment reflected the distinction between the government as owner and purchaser of outputs from a department. ${ }^{140}$ Appropriation by output works by the government deciding what outcomes they wish to achieve and then choosing outputs that they believe will enable the outcome to be met. Departments or other suppliers are then tasked with delivering the requested outputs with the freedom to choose the inputs to make that happen. ${ }^{141}$ Importantly output classes in the Estimates must specify the outcome they are there to meet. ${ }^{142}$ Finally, all appropriations were now expressed in accrual terms and not cash. ${ }^{143}$ This meant they reflected the full cost of acquiring them. ${ }^{144}$

The PFA 1989 made a number of other changes to appropriations and the Estimates. A new appropriation period was introduced. In addition to the existing permanent and annual appropriations there were now multi-year appropriations. The government is able to request and Parliament approve expenditure for up to five years. ${ }^{145}$ Appropriations were now made such that each Vote is linked to one responsible Minister and one department. Appropriations made to an office of Parliament had the Speaker as the responsible Minister for their Vote. ${ }^{146}$ The new system also clarified that Ministers are responsible for outcomes and the choice of outputs while chief executives are responsible for delivering outputs. ${ }^{147}$

\section{Committees}

The New Zealand Parliament has always had a committee responsible for examining government finance. There were various committees from 1854 before the first significant committee, the Audit Committee, was created in 1858. It was quickly replaced with the Public Accounts Committee (PAC) that was first appointed in $1870 .{ }^{148}$ PAC had a government chairperson and in the late 1940s was comprised of ten members with a

\footnotetext{
${ }^{139}$ Newbery and Pallot, 'A Wolf in Sheep's Clothing?', p. 271; The Treasury, 'A Guide to the Public Finance Act', August 2005, http://www.treasury.govt.nz/publications/guidance/publicfinance/pfaguide/ (20 July 2012), p. 21.

140 Treasury, 'Putting it Simply', p. 18.

${ }^{141}$ The Treasury, 'Putting it Together: An Explanatory Guide to the New Zealand Public Sector Financial Management System', June 1996, http://www.treasury.govt.nz/publications/guidance/publicfinance/pit// (20 July 2013), p. 14.

142 Treasury, 'Putting it Simply', p. 22.

143 Janssen, 'New Zealand's Fiscal Policy Framework', p. 519.

144 Boston, 'Financial Management Reform', p. 17.

145 Pallot, 'Financial Management Reform', p. 37.

146 ibid, p. 38.

${ }^{147}$ Ball, 'Changes in Accounting and Auditing Practices', p. 132.

${ }^{148}$ Egan, Wakelin and Yuill, Parliamentary Control, p 26.
} 
government majority. ${ }^{149}$ The PAC initially had strong terms of reference that allowed it to investigate the government's accounts and issues relating to the accounts. It was hoped at the committee's creation that it would be non-partisan. ${ }^{150}$ The PAC had a number of functions and practices that were important ingredients for future committees: it examined the Estimates from 1912, it considered bills that were referred to it, it questioned Treasury and department officials as a part of the Estimates examination and it occasionally considered the Auditor-General's report. Despite these various roles and responsibilities the PAC was a committee in constant decline. This was largely due to governments constraining its activity and the failure of the committee to regularly report to the House. The PAC's only remaining role when it was replaced was examination of the Estimates, which it did poorly, and it did not report to the House. ${ }^{151}$

The Public Expenditure Committee (PEC) replaced the PAC in 1962 on the recommendation of Parliament's Standing Orders Committee. The PEC was initially a committee of 12 MPs but was later reduced to 10 members. ${ }^{152}$ The committee had a government chairperson and government majority. PEC's terms of reference gave it significant roles and powers.

To examine the estimates presented to this House and to report what, if any, economies consistent with the policy implied on those estimates may be effected therein; to examine the public accounts and the accounts of such corporations, undertakings, and organisations as are in receipt of any more appropriated by Parliament, in such manner and to such extent as the Committee sees fit, and to have regard to matters in relation thereto raised in the annual report of the Controller and Auditor-General or elsewhere, and to report thereon to the House or the Government; and to examine and report on any such matters referred to it by the House; the Committee to have power to sit during the recess and to adjourn from time to time and from place to place and to have power to appoint sub-committees and to refer to such subcommittees any of the matters referred to the Committee. ${ }^{153}$

Furthermore, the PEC had bills with financial implications referred to it. ${ }^{154}$ The committee's consideration of the Public Finance Act 1977 (PFA 1977) set a strong precedent that Parliament's finance committee should consider bills with financial implications. ${ }^{155}$

\footnotetext{
${ }^{149}$ Polaschek, Government Administration, p. 241.

${ }^{150}$ Egan, Wakelin and Yuill, Parliamentary Control, p. 27.

151 ibid, pp. 28-30; John Martin, The House: New Zealand's House of Representatives, 1854-2004 (Palmerston North: Dunmore Press, 2004), p. 261.

152 von Tunzelmann, The Public Expenditure Committee, p. 36.

${ }^{153}$ Egan, Wakelin and Yuill, Parliamentary Control, pp. 32-33.

${ }^{154}$ McRobie, 'The New Zealand Public Expenditure Committee', p. 29.

${ }^{155}$ Leo, The Role of the Public Expenditure Committee and the Audit Office, p. 42.
} 
Two significant decisions made with the creation of the PEC have repercussions for the current committee arrangements. One contentious issue with the creation of the PEC was if it should have a government or an opposition chairperson. The government ensured that it held the chairpersonship but opposition MPs could serve as a subcommittee chairperson. It was a compromise of the British system, that New Zealand was replicating, which had a PAC with an opposition chairperson and an Estimates Committee with a government chairperson. ${ }^{156}$ The second significant decision was to have one committee with the combined functions of the two British committees. The conventional view is that a one committee structure was chosen because of the smaller Parliament. ${ }^{157}$ However, McRae claims that the real reason was the Standing Orders Committee being wrongly informed that Britain was merging its two committees. ${ }^{158}$

The PEC was ineffective at examining the Estimates. The committee's examination of the Estimates was no more effective than that of the PAC. It was 'largely superficial and perfunctory'. ${ }^{159}$ From 1972 the PEC maintained overall responsibility for the Estimates examination but it could now refer sets of Estimates to other select committees, although it continued to examine most itself. ${ }^{160}$ The new practice failed to meet expectations with neither the time spent nor the quality of examination improving. The main problems were insufficient time, both given and available, and a lack of MP expertise with what little there was concentrated in the PEC. ${ }^{161}$ The PEC continued to serve as an information source but it also stifled debate as MPs did not want to reiterate what had already been discussed in committee. ${ }^{162}$

The PEC was particularly notable for the inquiries that it carried out into matters relating to government expenditure. During Parliament's recess the PEC used subcommittees to carry out investigations into a wide range of topics related to government expenditure and administration. The subcommittees were frequently chaired by opposition MPs and were quite non-partisan. Topics for investigation could come from any source but the AuditorGeneral's Annual Report and the committee's own members were the major sources. ${ }^{163}$ The PEC's inquiries were far more effective than its examination of the Estimates. ${ }^{164}$

\footnotetext{
${ }^{156}$ Egan, Wakelin and Yuill, Parliamentary Control, p. 33.

${ }^{157}$ McRobie, 'The New Zealand Public Expenditure Committee', p. 31.

${ }^{158}$ McRae, A Parliament in Crisis, p. 89.

${ }^{159}$ McRobie, 'The New Zealand Public Expenditure Committee', p. 40.

${ }^{160}$ von Tunzelmann, The Public Expenditure Committee, p. 36.

161 ibid, p. 45-48.

${ }^{162}$ McRobie, 'The New Zealand Public Expenditure Committee', p. 40.

163 ibid, pp. 39-41.

${ }^{164}$ Leo, The Role of the Public Expenditure Committee and the Audit Office, p. 45.
} 
There are further aspects of the PEC that are applicable to the consideration of the current committee system. Significant attributes of the PEC, initially at least, included: its willingness to scrutinise the government, its determination to follow up on recommendations and its ability to get its reports debated in the House. ${ }^{165}$ The strength of the PEC was linked to the capability of its members, particularly the chairperson. ${ }^{166}$ The effectiveness of the PEC declined considerably once a ginger group moved up to Cabinet. ${ }^{167}$ The PEC operated under a problematic rule that prevented the committee from examining policy. ${ }^{168}$ Muldoon got around the problem as chairperson by only leniently enforcing the rule. ${ }^{169}$ The PEC lacked administrative and research assistance. ${ }^{170}$ However, the Clerk's Office did appoint an independent advisory officer from 1973 and the Audit Office an officer for liaison and technical advice from 1976. ${ }^{171}$

The 1985 overhaul of the select committee system had a major impact on the role of select committees in controlling and scrutinising government expenditure. Thirteen subject committees were created 'functionally related to Government departments'. ${ }^{172}$ The new committees had a principal legislative role but they were also to scrutinise policy, administration and expenditure of government departments. ${ }^{173}$ Among the new committees was the current Finance and Expenditure Committee (FEC) that replaced the PEC. The Committee is chaired by a government MP and has a government majority. However, in 1999 there was a non-government chairperson and the committee was evenly split. ${ }^{174}$ The FEC initially had five members like all the other select committees at the time. ${ }^{175}$ The committee has since expanded to have approximately 12 members. This is due to there no longer being a set number of select committee members. Size is determined by the Business Committee with proportionality the major factor. The FEC was made larger than other committees to allow all parties representation if they wish due to the committee's importance. ${ }^{176}$

\footnotetext{
165 Martin, The House, p. 262.

${ }^{166}$ Leo, The Role of the Public Expenditure Committee and the Audit Office, pp. 43-46.

${ }^{167}$ McRobie, 'The New Zealand Public Expenditure Committee', p. 35.

168 Shand, 'Parliamentary Control', p. 65.

${ }^{169}$ McRobie, 'Parliamentary 'Control' of Public Expenditure', p. 138.

${ }^{170}$ Leo, The Role of the Public Expenditure Committee and the Audit Office, p. 43.

171 von Tunzelmann, The Public Expenditure Committee, p. 50.

172 Geoff Skene, 'Parliamentary Reform', in Jonathan Boston and Martin Holland (eds.), The Fourth Labour

Government: Radical Politics in New Zealand (Auckland: Oxford University Press, 1987), p. 76.

173 ibid, p. 77.

${ }^{174}$ Elizabeth McLeay, 'Parliamentary Committees in New Zealand: A house continuously reforming itself?', Australasian Parliamentary Review, Vol. 16, No.2 (Spring 2001), p. 122.

175 Martin, The House, p. 307.

${ }^{176}$ McGee, Parliamentary Practice, pp. 244-245.
} 
The FEC has a different role to its predecessor. The FEC has a co-ordinating and overseeing role by having overall responsibility for examining the government's finances and its financial arrangements. ${ }^{177}$ The PEC examined government finance almost entirely on its own with the exception of some Estimates. The FEC now allocates the financial work out to the subject select committees as standard practice. ${ }^{178}$ For example, it is now expected that the Estimates will be examined by the select committee that has responsibility in that area. ${ }^{179}$ Furthermore, all select committees can now initiate their own inquiries, a power previously only held by the PEC. ${ }^{180}$ The Fiscal Responsibility Act 1994 (FRA) reinforced the FEC's role of examining the government's finances with the various reports required under the Act referred to it for consideration. ${ }^{181}$

The FEC has demonstrated its co-ordinating and overseeing role. In 1991 it developed the first standard estimates questionnaire designed to assist select committees with their Estimates examination. ${ }^{182}$ There was also a standard financial review questionnaire that was discontinued in 1997 with departments instead providing the information in their annual reports. ${ }^{183}$ The FEC has continued its predecessor's role of considering on behalf of the House proposed changes to the format and content of financial information presented to the House. The PFA 1989 has reinforced this requiring that the House is consulted on changes to the content or format of an Appropriation Bill. Furthermore, it considers financial management legislation including the PFA 1989 and has reported on financial management issues. ${ }^{184}$ A further change from 1994 has been Ministers appearing before select committees as a part of their Estimates examination. ${ }^{185}$ Previously only officials appeared before committees. The change reflects that appropriations are now made to a responsible Minister. ${ }^{186}$

Controller and Auditor-General ${ }^{187}$

\footnotetext{
177 Jackson, The Dilemma of Parliament, p. 154.

${ }^{178}$ McGee, Parliamentary Practice, p. 451.

${ }^{179}$ G.A. Wood and Chris Rudd, The Politics and Government of New Zealand: Robust, Innovative and Challenged (Dunedin: University of Otago Press, 2004), p. 73.

${ }^{180}$ McGee, Parliamentary Practice, pp. 426-427.

181 ibid, p. 452.

182 ibid, p. 481.

183 ibid, p. 511.

184 ibid, p. 452.

185 ibid, p. 283.

186 ibid, p. 482.

${ }^{187}$ Historically, the Controller and Auditor-General, the Deputy Controller and the staff employed in the Audit Department were known together as the Audit Office. Pallot, 'Accounting, Auditing, and Accountability', p. 76.
} 
New Zealand's Auditor-General originates from an Audit Branch, followed by an Audit Board established in the early 1840s, which reported to the British Commissioners of Audit. The first Auditor was appointed in 1846. ${ }^{188}$ The Audit Act 1858 created an independent Auditor, with the exception of being appointed by the Governor-General, who was responsible to Parliament and not the government. ${ }^{189}$ The Audit Act 1858 was repealed in 1867 with the Public Revenues Act. As a result the Auditor no longer had its own piece of legislation and independence from government. ${ }^{190}$ The Auditor-General would not have its independence restored and its own piece of legislation again until 2001. A controller, then known as Comptroller of the Public Accounts, was introduced in 1865. The positions of Comptroller and Auditor-General were combined by the Public Revenues Act 1878 to create the Controller and Auditor-General (Auditor-General). ${ }^{191}$ The legal framework for the Auditor-General remained relatively unchanged until the PFA 1977. The exception was the Public Revenues Act 1910 that required the Auditor-General to submit an annual report to Parliament. ${ }^{192}$

The Auditor-General has developed a close relationship with Parliament and its committees. The close relationship started with the Auditor-General sending an observer to the PAC from 1952. The relationship became far closer with the introduction of the PEC. ${ }^{193}$ The relationship was closer due to the assistance the Auditor-General provided the committee and the committee's consideration of the Auditor-General's Annual Report. ${ }^{194}$ The relationship between the Auditor-General and the FEC took a step backwards in 1988 due to the Strategos Report that created unnecessary friction between the two. ${ }^{195}$ The 1994 resignation of the Auditor-General did not help the relationship or the Audit Office's position. ${ }^{196}$ However, the relationship would improve in the 1990 s because the role of the Auditor-General, particularly in providing support to select committees, was further recognised with increased assistance given to Parliament. The result was a parliamentary

\footnotetext{
188 Polaschek, Government Administration, p. 7.

${ }^{189}$ Martin, The House, p. 56.

${ }^{190}$ McRae, A Parliament in Crisis, p. 40.

${ }^{191}$ Egan, Wakelin and Yuill, Parliamentary Control, p. 23.

192 ibid, p. 26.

193 ibid, p. 25.

194 von Tunzelmann, The Public Expenditure Committee, p. 68.

195 Pallot, 'Accounting, Auditing, and Accountability', pp. 80-82; Pallot, 'A Wider Accountability', p. 269.

196 Pallot, 'A Wider Accountability', p. 278.
} 
group within the Audit Office responsible for managing the relationship with Parliament and its committees. ${ }^{197}$

The PFA 1977 significantly changed the scope of the audits that the Audit Office could carry out. By the beginning of the 1970s the Audit Office was stretching its auditing mandate by commenting on wasteful or extravagant expenditure. ${ }^{198}$ The legislation in place, the Public Revenues Act 1953, did not give the Audit Office the authority to carry out value for money audits. ${ }^{199}$ The Audit Office subsequently pushed to expand its own auditing mandate. ${ }^{200}$ The PFA 1977 allowed it to carry out value for money or performance audits. The ability to carry out value for money audits meant that the Audit Office could audit for the efficiency and effectiveness of expenditure. ${ }^{201}$ The Audit Office was given 'considerable power and autonomy' because it was to interpret the provision itself. ${ }^{202}$ However, the Audit Office could not question the merits of government policy as a part of the audit. ${ }^{203}$

The PFA 1989 had a significant impact on the Audit Office despite leaving in place the main part of the PFA 1977 relating to the Auditor-General. ${ }^{204}$ The Audit Office was involved in creating and implementing the PFA $1989 .{ }^{205}$ The move to accrual accounting and the need to audit non-financial information meant new demands were placed on auditors. ${ }^{206}$ The new reporting requirements introduced by the PFA 1989 meant that the Audit Office now attested to the contents of the new annual reports rather than having to make substantive comments. This resulted in performance auditing being more targeted at the needs of Parliament. ${ }^{207}$

The PFA 1989 contributed to a change in structure for the Auditor-General and the contracting out of auditing. The Audit Office's monopoly on public sector auditing did not fit with the reforms of the late 1980s which stressed contestability and the need to show efficiency and effectiveness. ${ }^{208}$ The Audit Office was subsequently split into two units, consistent with other splits in the public sector during the same period. The first unit was the Office of the Auditor-General which was responsible for standard setting, overseeing auditing and dealing with Parliament. The second unit was Audit New Zealand that was contracted by

\footnotetext{
${ }^{197}$ Kerry Jacobs, 'Value for Money Auditing in New Zealand: Competing for control in the public sector', British Accounting Review, Vol. 30, No. 4 (December 1998), p. 356.

${ }^{198}$ Skene, 'Auditing, Efficiency and Management', p. 274.

199 Jacobs, 'Value for Money Auditing in New Zealand', p. 348.

200 Skene, 'Auditing, Efficiency and Management', p. 276.

${ }^{201}$ Pallot, 'A Wider Accountability', p. 285.

202 Jacobs, 'Value for Money Auditing in New Zealand', p. 349.

203 ibid, pp. 347-348.

${ }^{204}$ Pallot, 'Accounting, Auditing, and Accountability', p. 83.

205 Pallot, 'A Wider Accountability', p. 271.

206 Pallot, 'New Public Management Reform', p. 225.

207 Jacobs, 'Value for Money Auditing in New Zealand', p. 357.

${ }^{208}$ Pallot, 'New Public Management Reform', p. 225.
} 
the Auditor-General to carry out audits. The carrying out of audits was made contestable through tender with private sector auditors and Audit New Zealand competing for audit work. The tendering of audits was done to show efficiency and value for money, and to draw on private sector knowledge. ${ }^{209}$

The Public Audit Act 2001 (PAA) gave the Auditor-General its own piece of legislation and made it an officer of Parliament. ${ }^{210}$ Earlier in 1990 the Audit Office became financially independent of government when it was treated as an office of Parliament in the appropriations process. ${ }^{211}$ As a full officer of Parliament from 2001 the Auditor-General was now independent both financially and operationally from the government. ${ }^{212}$ It was responsible only to Parliament, emphasised by it presenting a draft annual plan for consideration by the Speaker and a select committee. ${ }^{213}$ The appointment issue was likewise addressed with the first appointment of a new Auditor-General on the recommendation of Parliament in 2002. ${ }^{214}$ The PAA also made it so that all public sector entities were covered consistently by the Auditor-General's mandate. Furthermore, the Auditor-General could now check for legislative compliance and probity; work Parliament wanted it to carry out. ${ }^{215}$

How the Auditor-General performed the controller function changed following the PFA 1989 and the Public Finance Amendment Act 2004. The controller function had historically been performed by:

Periodic certification by the Controller and Auditor-General to the Governor-General that payments to be made out of the Crown bank account (under a warrant signed by the GovernorGeneral) could be lawfully made; and

Regular (in practice, daily) certification that amounts to be paid out of the Crown bank account were pursuant to a warrant by the Governor-General, and that there was an appropriation or other authority against which each payment could be charged. ${ }^{216}$

This system was rendered ineffective by the shift to accrual accounting and subsequently offered little in the way of a check. ${ }^{217}$ The Auditor-General sought to address the weakness by developing the audit of appropriations in the 1990s. ${ }^{218}$ The audit of appropriations, performed well after the event during the annual audit, involved checking that departments

\footnotetext{
209 Pallot, 'A Wider Accountability', pp. 274-275.

210 ibid, p. 281.

211 ibid, p. 275.

212 ibid, p. 281.

213 ibid, p. 286.

${ }^{214}$ McGee, Parliamentary Practice, p. 74; Pallot, 'A Wider Accountability', p. 275.

${ }^{215}$ McGee, Parliamentary Practice, p. 505.

${ }^{216}$ Controller and Auditor-General, 'Central Government: Results of the 2003-04 Audits', B.29[05a], (March

2005), http://www.oag.govt.nz/2005/2003-04/docs/central-govt.pdf (17 July 2013), p. 53.

217 Auditor-General, 'Central Government', p. 52; McGee, Parliamentary Practice, p. 455.

218 ibid, p. 53.
} 
had met all the requirements for each appropriation during the financial year. ${ }^{219}$ The Public Finance Amendment Act 2004 ended the warrant and certification approach. ${ }^{220}$ The audit of appropriations which had previously been carried out under the Auditor-General's auditing standards was now a statutory requirement. ${ }^{221}$ In addition, the Treasury was now required to present a monthly report to the Auditor-General on appropriations. ${ }^{222}$ The next chapter elaborates on how the controller function is currently performed.

\section{Parliamentary Procedure}

New Zealand has shifted away from the principle that only the government can propose expenditure in Parliament. The New Zealand Constitution Act 1852 set out that Parliament could only consider expenditure proposals from the Crown and the principle was enforced in Standing Orders. ${ }^{223}$ The principle was reaffirmed with the Constitution Act 1986 but the particular section was repealed in $2005 .{ }^{224}$ Under the appropriation rule in Standing Orders any bill or amendment from a non-ministerial MP that involved expenditure was deemed out of order, unless it had support from the Crown in the form of a message from the GovernorGeneral. However, MPs could propose a decrease, but not an increase, to a Vote in an Appropriation Bill. ${ }^{25}$ The appropriation rule was too constraining on MPs and failed to properly protect the Crown's financial position. The appropriation rule was replaced by the financial veto procedure in $1996 .{ }^{226}$ The financial veto procedure allows MPs to present bills and amendments that propose expenditure as well as decreases and increases to an Appropriation Bill. The government though has the ability to veto any proposal that it believes will have a more than minor impact on its fiscal aggregates. ${ }^{227}$

Parliament's Budget process previously operated around the Committee of Supply, a Committee of the Whole House. Before the abolition of the committee the process started with the presentation of the Budget to the House with the Estimates subsequently tabled. There was then a Budget debate starting with a financial statement from the Minister of

\footnotetext{
219 ibid, pp. 53-54.

220 ibid, p. 53.

221 ibid, p. 55.

${ }^{222}$ McGee, Parliamentary Practice, p. 455.

${ }^{223}$ Scott, The New Zealand Constitution, pp. 56-57.

${ }^{224}$ Palmer and Palmer, Bridled Power, p. 118; New Zealand Parliament, 'Constitution Act 1986', 17 May 2005 , http://www.legislation.govt.nz/act/public/1986/0114/latest/DLM94204.html (7 June 2013).

${ }^{225}$ Power, The Financial Veto, pp. 8-10.

${ }^{226}$ McGee, Parliamentary Practice, p. 447.

227 ibid.
} 
Finance. ${ }^{228}$ The House or the government referred the Estimates to committee and reported to government or the House, depending on the year in question. Following that the Committee of Supply approved the Estimates item by item. The House later considered the Supplementary Estimates separately in much the same way. The main Estimates and the Supplementary Estimates were then put into one Appropriation Bill which was introduced and passed. ${ }^{229}$ The Committee of Supply was abolished in 1968. It was no longer considered particularly relevant considering its British origins. ${ }^{230}$

The Committee of Supply was replaced with a process centred on Appropriation Bills. The new process that was created by the Standing Orders Committee sought to clean up the previous process. ${ }^{231}$ In summary, under the new system the Budget was presented to the House by the Minister of Finance with an Appropriation Bill introduced that had the main Estimates attached as a schedule. The Budget debate was held during the second reading of the Appropriation Bill starting with the Minister of Finance's Budget statement. The main Estimates were referred to the PEC who considered them. The committee did have the power to report on them but it generally chose to pass a formal resolution returning them to the House without comment. The House subsequently debated the main Estimates in a Committee of the Whole House on an Appropriation Bill for two days each week during the parliamentary session. ${ }^{232}$ The Supplementary Estimates were considered in a second Appropriation Bill using a similar process. ${ }^{233}$

Following the change to the Appropriation Bill system there have been two significant changes made to the parliamentary process. In 1972 Parliament adopted the recommendation of the Standing Orders Committee that the Estimates debate be reduced to 16 sittings days, with the concession made to the opposition that they would determine what Votes were debated. Any Votes not debated were considered passed without debate. ${ }^{234}$ The second significant change occurred in 1992 when the Estimates and the review of departmental spending were separated. ${ }^{235}$ Previously the House and select committees had dealt with the

\footnotetext{
${ }^{228}$ Martin, The House, p. 121.

${ }^{229}$ Leicester Webb, Government in New Zealand (Wellington: Department of Internal Affairs, 1940), pp. 108110; Beck, Downey, Hayes and Wood, The Control of Government Expenditure, pp. 7-10.

${ }^{230}$ Egan, Wakelin and Yuill, Parliamentary Control, p. 34.

${ }^{231}$ Martin, The House, p. 263.

${ }^{232}$ Egan, Wakelin and Yuill, Parliamentary Control, pp. 39-45; Treasury, The Planning and Control of Government Expenditures, pp. 8-9.

${ }^{233}$ Martin, The House, p. 264.

${ }^{234}$ Treasury, The Planning and Control of Government Expenditures, p. 9.

${ }^{235}$ Martin, The House, p. 319.
} 
two together. ${ }^{236}$ The new procedure features three segments of examination and debate by the House and committees: Estimates for the upcoming year, the financial performance of departments over the previous financial year and the financial performance of State enterprises (SOEs) and Crown agencies over the previous financial year. ${ }^{237}$ This is reflected in separate Appropriation (Estimates) and Appropriation (Financial Review) Bills.

An historical theme of the Estimates debate has been the constraints placed on MPs in terms of what they are allowed to discuss. Before 1972 MPs were not allowed to discuss policy in debates on the Estimates. The rule was not actually in Standing Orders but had been developed over time by chairpersons with the Speakers' support as a part of the ability to rule on relevancy in debate. ${ }^{238}$ The rule was eased slightly in 1967 with MPs able to debate the content of department's annual reports. Determining the line between expenditure and administration and policy was a problem. ${ }^{239}$ From 1972 MPs were permitted to debate policy as a part of the Estimates debate. The Estimates debate subsequently changed from a focused discussion on expenditure and administration to a more general debate. In 1985 the Standing Orders Committee sought to tighten up the Estimates debate with the rule of relevancy. The rule of relevancy was such that the Estimates debate should be about the Estimate currently being debated. Discussion of the policy behind the government's request was allowed but general policy debate was discouraged. The separation of Estimates and of financial review meant that the Estimates debate was on planned expenditure and not past performance. ${ }^{240}$

A further theme of the House's parliamentary procedure has been the steadily decreasing length of the Estimates debate. When the new process centred on the Appropriation Bill was introduced the Estimates were debated for two sitting days each week. ${ }^{241}$ The Estimates debate which had been set at 16 days in 1972 had become 13 days by 1992 when it was reduced to 20 hours. In 1999 it was reduced further to eight hours. The financial review debate introduced in 1992 when Estimates and the review of the previous year's expenditure were separated was initially ten hours but was also reduced in 1999 to four hours. ${ }^{242}$

\section{Accounts and the Consolidated Fund Principle}

\footnotetext{
${ }^{236}$ Egan, Wakelin and Yuill, Parliamentary Control, p. 40.

${ }^{237}$ Palmer, New Zealand's Constitution, p. 126.

${ }^{238}$ McGee, Parliamentary Practice, p. 485.

${ }^{239}$ Egan, Wakelin and Yuill, Parliamentary Control, pp. 42-43.

${ }^{240} \mathrm{McGee}$, Parliamentary Practice, p. 485.

${ }^{241}$ Egan, Wakelin and Yuill, Parliamentary Control, p. 42.

${ }^{242}$ Newbery and Pallot, 'A Wolf in Sheep's Clothing?', p. 270
} 
Parliament from early on was regularly presented with a copy of the government's accounts. A constant problem with the accounts has been that only a few people could understand them and attempts to make them more useable generally failed. ${ }^{243}$ Until 1989 New Zealand used cash accounting that reported transactions that had been made during the financial year. Cash accounting left out important information such as assets and the costs of producing outputs (goods and services). ${ }^{244}$ Pallot explains that cash accounting distorts the assessment of financial performance because it 'records items when cash is received or paid without regard to the period to which they apply'. ${ }^{245}$ In the 1930 s there was a limited experiment with using private sector accounting practices in the public sector but the idea would not be properly implemented for fifty years. ${ }^{246}$

The PFA 1989 significantly changed the government's accounting practices and the nature of its accounts. The PFA 1989 made the government use the same accounting practices as the private sector. More specifically the PFA 1989 set out that the Crown, government departments and Crown entities in all of their financial statements were to follow the generally accepted accounting practice (GAAP). The move to GAAP meant that accrual accounting was adopted, replacing the previous cash accounting system. Accrual accounting primarily results in accounts showing 'resources used in the production of goods or services with the revenues or services generated in the same period'. ${ }^{247}$ Importantly, accrual accounting means that assets including depreciation are now included in the government's accounts. $^{248}$ In layman's terms the use of accrual accounting means that it is no longer possible to hide the costs of decisions'. ${ }^{249}$ Accrual accounting was steadily rolled in over the two years following the PFA 1989. By July 1991 all government departments were using accrual accounting. ${ }^{250}$ The Financial Reporting Act 1993 created the independent Accounting Standards Review Board that determines accounting standards that meet GAAP. ${ }^{251}$ As a result the government no longer sets its own accounting rules, and improved its transparency through preventing potential manipulation. ${ }^{252}$ In 2007 international financial reporting

\footnotetext{
${ }^{243}$ Egan, Wakelin and Yuill, Parliamentary Control, p. 21.

244 Treasury, 'Putting it Together', 1996, p. 18.

${ }^{245}$ Pallot, 'Accounting, Auditing, and Accountability', p. 57.

${ }^{246}$ Webb, Government in New Zealand, p. 116.

247 Pallot, 'Accounting, Auditing, and Accountability', p. 57.

248 Palmer, New Zealand's Constitution, p. 126.

${ }^{249}$ Pallot, 'New Public Management Reform', p. 233.

250 ibid, p. 229.

${ }^{251}$ Palmer and Palmer, Bridled Power, p. 125.

${ }^{252}$ Pallot, 'New Public Management Reform', p. 231.
} 
standards (IFRS) were adopted. ${ }^{253}$ The use of IFRS meant the government's accounting practices were aligned with best international practice. ${ }^{254}$

The principle of a consolidated fund has generally been followed with a few exceptions. New Zealand historically had an account called the consolidated fund but it had been replaced by the 1980s. ${ }^{255}$ Prior to the PFA 1989 the government's accounts centred on the Public Account that was comprised of a number of accounts including the Consolidated Account that carried out the consolidated fund role. ${ }^{256}$ The consolidated fund principle though had been deviated from in a number of ways. McGee points out that some departments were allowed to keep and reuse money they had made without it going into the consolidated fund and 'that there was more than one fund'. ${ }^{257}$ Egan, Wakelin and Yuill provide further examples including government trading activities and permanent appropriations. ${ }^{258}$ There has been a tendency to use permanent appropriations to avoid parliamentary scrutiny with several efforts being made to return expenditure to the appropriations process. $^{259}$

The government's accounts and reporting requirements prior to 1989 were incomprehensive and inconsistent. Preston points out that information on the government's accounts was spread across a number of documents with no single document providing a complete picture. ${ }^{260}$ A Public Account statement was presented to Parliament each year. It was limited by a number of accounts, in particular trading enterprises, being outside the Public Account. Some aspects of these outside accounts were included in the Estimates and in tables that were a part of the Budget. ${ }^{261}$ Preston argues that the financial information in the Budget made it the 'closest document to an annual financial report from the Government to Parliament'. ${ }^{262}$ Departmental annual reports included financial information for trading and

\footnotetext{
${ }^{253}$ Susan Newberry, 'Whole of Government Accounting in New Zealand: A Review of WGA Financial Reports From 1993 to 2010', Abacus, Vol. 47, No. 4 (2011), p. 507.

${ }^{254}$ The Treasury, 'Putting it Together: An Explanatory Guide to New Zealand's State Sector Financial Management System', September 2011, http://purl.oclc.org/nzt/g-pit2011 (20 July 2012), p. 13.

${ }^{255}$ McGee, Parliamentary Practice, 1985, p. 300.

256 David Preston, Government Accounting in New Zealand: an explanation of the accounting and financial system of the central Government of New Zealand (Wellington: Government Printer, 1980), pp. 49-50.

${ }^{257}$ McGee, Parliamentary Practice, p. 443.

${ }^{258}$ Egan, Wakelin and Yuill, Parliamentary Control, pp. 21-22.

${ }^{259}$ Martin, The House, p. 261; McRobie, 'Parliamentary 'Control' of Public Expenditure', p. 125; Egan, Wakelin and Yuill, Parliamentary Control, pp. 21-22.

${ }^{260}$ Preston, Government Accounting in New Zealand, p. 48.

261 ibid, pp. 48-56.

262 ibid, p. 48.
} 
non-trading departments. ${ }^{263}$ However, there were no consistent reporting requirements for Crown agencies with some even having no financial reporting requirements. ${ }^{264}$

The PFA 1989 further adjusted adherence to the consolidated fund principle and significantly changed reporting requirements. The PFA 1989 allowed for the holding of public money in the new Crown bank account that replaced the Public Account and in new departmental bank accounts. ${ }^{265}$ Although there was now more than one account the consolidated fund principle was still followed. Adherence to the consolidated fund principle was enhanced with the introduction of consolidated financial statements or whole of government accounting. The consolidated financial statements brought together the financial statements of departments, offices of Parliament, Crown agencies and State enterprises (SOEs) into one document. ${ }^{266}$ The document shows the full size and extent of the government's finances and financial activity. ${ }^{267}$ The first accrual consolidated financial statement was produced in 1992. ${ }^{268}$ The PFA 1989 also introduced new financial statements meeting GAAP that improved and made more consistent the reporting requirements for the new Crown entities as well as departments and offices of Parliament. ${ }^{269}$ The new financial statements and reporting requirements improved transparency and made the government more accountable to Parliament and the public. ${ }^{270}$

\section{Fiscal Responsibility Act and High Level Scrutiny}

The FRA facilitated greater high level examination of the government's financial management, consequently enhancing Parliament's ability to control and scrutinise government expenditure. The Act was introduced for a number of reasons: the feared effect of MMP and to ensure that future governments factored in and were transparent about the long term impact of their financial decisions, as well as the lack of accurate financial information available in the run up to an election. ${ }^{271}$ The FRA complemented the earlier PFA 1989. The PFA 1989 was "concerned with the "micro" side of the Budget process', 272 supporting parliamentary control and scrutiny of government expenditure at the appropriation

\footnotetext{
263 ibid.

${ }^{264}$ Pallot, 'Accounting, Auditing, and Accountability', pp. 63-64.

265 Pallot, 'Financial Management Reform', p. 38.

266 ibid, p. 38.

${ }^{267}$ Audit Office, Central Government Management: A New Approach (Wellington: Audit Office, 1989), pp. 1617.

268 Pallot, 'New Public Management Reform', p. 229.

${ }^{269}$ Pallot, 'Accounting, Auditing, and Accountability', pp. 63-64.

${ }^{270}$ Ball, 'Changes in Accounting and Auditing Practices', p. 136.

${ }^{271}$ Scott, 'New Zealand's Fiscal Responsibility Act', p. 4.

272 Dale, 'the Budget Process', p. 237.
} 
level. The FRA focused on the 'macro' or higher level. ${ }^{273}$ The Act as such enhanced the ability of Parliament to scrutinise government economic and fiscal management, including expenditure, as a whole. The FRA centred on requiring the government to set out its fiscal objectives and subsequently report on the extent to which it met those objectives. ${ }^{274}$ To enable that, the government and Treasury were required to produce new reports and the principles of responsible fiscal management were introduced.

The principles of responsible fiscal management introduced by the FRA provided a framework for examining government fiscal management. The FRA sets out five principles that the government is to factor in when developing the Budget. ${ }^{275}$ The principles are not mandatory but the government does have to explain why it has departed from them and how it intends to meet the principles again in the future. ${ }^{276}$ Any departure from the principles was to be transparent and only temporary. ${ }^{277}$ The FRA did not define key words such as 'prudent' or 'reasonable' and they were left to the government to interpret. ${ }^{278}$ The Treasury summarises the five principles as being:

- 'reducing Crown debt to a prudent level,

- maintaining Crown debt at a prudent level

- achieving and maintaining Crown net worth at a level that provides a buffer against adverse future events

- prudent management of fiscal risk

- reasonably predictable tax rates'. ${ }^{279}$

Government expenditure fits under the first and second principles due to the balancing of expenditure and revenue needed to reduce and maintain prudent debt levels.

The FRA introduced new reporting requirements for the government and the Treasury that facilitated a higher level of scrutiny of government expenditure. The government had to produce a budget policy statement and a fiscal strategy report and the Treasury economic and fiscal updates. Scott states that the new reports provided 'for regular and explicit fiscal reporting; for parliamentary review of fiscal reports; for a set of benchmarks against which fiscal policies can be assessed; and for more open budgetary processes' ${ }^{280}$ All three of the

\footnotetext{
273 ibid.

${ }^{274}$ Pallot, 'New Public Management Reform', p. 230.

275 Scott, 'New Zealand's Fiscal Responsibility Act', p. 3.

276 Janssen, 'New Zealand's Fiscal Policy Framework', p. 522.

${ }^{277}$ Pallot, 'New Public Management Reform', p. 230.

278 Janssen, 'New Zealand's Fiscal Policy Framework', p. 522.

279 Treasury, 'Putting it Together', 1996, p. 11.

${ }^{280}$ Scott, 'New Zealand's Fiscal Responsibility Act', p. 3.
} 
new reports were referred to the FEC for scrutiny. ${ }^{281}$ The Public Finance Amendment Act 2004 merged the FRA into the PFA 1989 in order to consolidate public finance legislation with minor changes made to requirements for the three reports. ${ }^{282}$ Importantly the new reports were to meet GAAP. ${ }^{283}$ The contents of the three reports are described in the next chapter.

\section{Conclusion}

This chapter has summarised the history of parliamentary practice and procedure that enabled Parliament to carry out its control and scrutiny of government expenditure function. It has highlighted the significant changes made to the key features that New Zealand inherited from Britain. The changes have been drastic with many concentrated in recent decades. Significant changes include the move from the Audit Committee through to the FEC, the shift in the bases of appropriations and the accounts to outputs, and Parliament's evolved procedure for dealing with financial business. A further feature has been added with the FRA. It introduced new reports and the principles of responsible fiscal management that improved Parliament's ability to scrutinise government expenditure at a high level. This history has raised a number of issues and trends that need to be addressed when evaluating Parliament's current ability to carry out the control and scrutiny of government expenditure function. Such issues and trends include: the capability of Parliament's FEC, the quality and length of debate particular in that on the Estimates; the capability of MPs to deliver on the function; and the appropriateness of output and accrual based appropriations and accounts. The next chapter will describe Parliament's current practice and procedures for controlling and scrutinising government expenditure and stressing the key features that have been the focus of this history chapter.

\footnotetext{
281 ibid.

282 Treasury, 'A Guide to the Public Finance Act', pp. 42-43.

${ }^{283}$ Pallot, 'New Public Management Reform', p. 231.
} 


\section{Chapter Three: Current Practice and Procedure}

\section{Introduction}

Parliament has extensive practice and procedure for controlling and scrutinising government expenditure. Before Parliament's capability to perform the function can be evaluated it is necessary to describe how it is performed. Parliament's practice and procedure is not specified in any one document or piece of legislation. The most important sources are the Public Finance Act 1989 (PFA), the Public Audit Act 2001 (PAA) and the Standing Orders of the House of Representatives 2011 (Standing Orders or S.O.) with a number of other pieces of legislation containing important components. This chapter starts by identifying the core legal provisions, system of appropriations and documentation that facilitate Parliament's control and scrutiny of government expenditure. It then describes the supply and financial review processes that grant permission to the government to spend public money and check how that money was spent. The other key elements are then discussed including the accounts and accounting, the Controller and Auditor-General (Auditor-General) and the Finance and Expenditure Committee (FEC).

\section{Central Provisions}

\section{Parliamentary Consent}

Parliament's function of controlling and scrutinising government expenditure is enabled by a central provision that the Crown must have parliamentary consent to spend public money. Three pieces of legislation specify that the Crown needs the consent of Parliament to spend public money. The Bill of Rights 1688 provides that the Crown requires a grant from Parliament to spend public money and that it must be spent in the time period and for the purpose specified. ${ }^{284}$ The Constitution Act 1986 states that the Crown cannot lawfully spend public money unless it has Parliament's approval by or under an Act. ${ }^{285}$ The PFA reiterates and further defines the provisions contained in the aforementioned legislation stating that the 'The Crown or an office of Parliament must not spend public money, except as expressly

${ }^{284}$ New Zealand Parliament, 'Bill of Rights Act 1688', 1 January 1989, http://www.legislation.govt.nz/act/imperial/1688/0002/latest/DLM10993.html (7 June 2013), Article 4; New Zealand Parliament, 'Imperial Laws Application Act 1988', 5 August 2013, http://www.legislation.govt.nz/act/public/1988/0112/latest/DLM135074.html (7 June 2013), s.3.

${ }^{285}$ Constitution Act 1986, s.22. 
authorised by or under an Act (including this Act)' ${ }^{286}$ As such it ensures that offices of Parliament must also adhere to the provision and that public money can be spent if authorised by the Act itself.

\section{Financial Responsibility of the Crown}

The other central provision is the financial responsibility and required initiative of the Crown. The Crown must 'take the initiative in financial matters'; it is both a statutory and a political duty. ${ }^{287}$ It is a political duty because the Crown is responsible for the functioning of government through its Ministers with a key aspect being the responsibility for financial matters including government expenditure. ${ }^{288}$ The Crown's financial responsibility and its need to take the initiative are reflected in the requirement that the first Appropriation Bill be introduced within one month of the beginning of every financial year. ${ }^{289}$ The government's financial initiative and responsibility means it 'cannot have fiscal policies foisted upon it'. ${ }^{290}$ The government is constrained to an extent by the requirement that policy objectives are pursued in accordance with the five principles of responsible fiscal management. The government may depart from the principles but any departure should only be temporary. The Minister of Finance must explain why the government has departed from the principles, how they will return to following them and how long that will take. ${ }^{291}$ The principles are only guidelines with no formal punishment for failing to follow them. ${ }^{292}$ The financial responsibility documents articulate the government's following of the principles.

\section{Crown's Financial Veto}

The Crown's financial responsibility is demonstrated and reinforced with the financial veto. The financial veto prevents the House from passing a bill, amendment or motion that the government believes will have a more than minor impact on the its fiscal aggregates or from making a change to a Vote that the government believes will have a more than minor impact on its composition. ${ }^{293}$ The government must deliver a financial veto certificate with an

\footnotetext{
${ }^{286}$ New Zealand Parliament, 'Public Finance Act 1989', 6 March 2013, http://www.legislation.govt.nz/act/public/1989/0044/latest/DLM160809.html (21 July 2012), s.5.

${ }^{287}$ McGee, Parliamentary Practice, p. 446.

288 ibid.

${ }^{289}$ PFA, s. 12.

${ }^{290}$ McGee, Parliamentary Practice, p. 446.

${ }^{291}$ PFA, s.26G.

${ }^{292}$ McGee, Parliamentary Practice, p. 446.

${ }^{293}$ New Zealand House of Representatives, 'Standing Orders of the House of Representatives 2011', 5 October 2011, http://www.parliament.nz/resource/0000238125 (21 July 2012), S.O.321.
} 
explanation of the nature of the impact and why it does not concur with the proposal. A financial veto certificate may be debated when the House next considers the bill, amendment, motion or Vote and the government may withdraw a certificate at any time. ${ }^{294}$ The financial veto may only be used at specified stages of the parliamentary process. ${ }^{295}$ MPs must give notice for an amendment that could have a minor impact on fiscal aggregates or a move to change a Vote. ${ }^{296}$ The financial veto ensures that MPs have the opportunity to scrutinise government policies that involve expenditure through proposing alternatives. The financial veto reinforces government responsibility because it prevents the Crown from having to take responsibility for proposals that involve government expenditure that it does not agree with. $^{297}$

\section{Supply and Confidence}

Parliament grants the government the right to spend public money by providing supply. McGee explains that 'Parliament's consent to the expenditure of public money is often known as the granting of supply'. ${ }^{298}$ Parliament provides supply through the annual supply process that passes various Appropriation Acts. ${ }^{299}$ The supply process centres on the main Appropriation Bill presented with the Budget, 'the government's principal annual statement of economic and fiscal policy,. ${ }^{300}$ Key votes in the supply process on Imprest Supply Bills and Appropriation Bills serve as confidence votes in the government. ${ }^{301}$ The government requires supply to function with the potential for Parliament to withhold supply serving as a major check on the government. ${ }^{302}$ The government's need to obtain supply allows for the control and scrutiny of government expenditure. Furthermore, it ensures that Parliament meets each year with the sitting schedule influenced by the various pieces of financial business that must be brought before the House. ${ }^{303}$

\footnotetext{
294 S.O.322.

295 S.O.323-324.

296 S.O.325.

${ }^{297}$ McGee, Parliamentary Practice, p. 446.

298 ibid.

${ }^{299}$ Palmer and Palmer, Bridled Power, p. 119; McGee, Parliamentary Practice, p. 470.

300 ibid, p. 119.

301 ibid, p. 120.

302 ibid.

${ }^{303}$ McGee, Parliamentary Practice, p. 446.
} 


\section{Appropriations}

Parliament in the supply process considers appropriations requested by the government in Appropriation Bills. An appropriation is 'a parliamentary authorisation for the Crown or an office of Parliament to incur expenses or capital expenditure' ${ }^{304}$ Appropriations enable the incurring of expenses or capital expenditure because that is how public money is spent under accrual accounting. ${ }^{305}$ Accrual appropriations show the full resource cost of an appropriation, not just the cash cost, with expenditure counted in the period the activity occurred or will occur. ${ }^{306}$ The nature of appropriations means that the provision preventing the expenditure of public money without authorisation from Parliament alone is inadequate. ${ }^{307}$ As such the Crown or an office of Parliament must have authorisation from Parliament in an appropriation or other authority to incur expenses or capital expenditure. ${ }^{308}$ Accrual appropriations are able to work because public money can be used to meet expenses and capital expenditure incurred in accordance with an appropriation or other authority. ${ }^{309}$ The government must have the legal authority to undertake what is proposed in an appropriation. ${ }^{310}$ Appropriations do not provide the legal authority themselves with the exception of permanent legislative authorities. ${ }^{311}$ There is no obligation to use an appropriation. $^{312}$

Key aspects of appropriations create clear accountability for expenditure. Appropriations centre on the concepts of inputs, outputs and outcomes. Inputs are the resources used to produce goods and services known as outputs. ${ }^{313}$ Outputs are designed to contribute to outcomes 'a state or condition of society, the economy, or the environment and includes change in that state or condition'. ${ }^{314}$ The government is held accountable for its choice of desired outcomes and the outputs it purchases to meet them. ${ }^{315}$ Accountability is established through ministerial responsibility for appropriations. Appropriations are organised into Votes with each comprising one appropriation or a group of similar or related

\footnotetext{
304 Treasury, 'A Guide to the Public Finance Act', p. 81.

${ }^{305}$ McGee, Parliamentary Practice, p. 444.

306 Treasury, 'Putting it Together', p. 31.

${ }^{307}$ McGee, Parliamentary Practice, p. 444.

308 PFA, s.4.

${ }^{309}$ PFA, s.6; Treasury, 'A Guide to the Public Finance Act', p. 12.

${ }^{310}$ McGee, Parliamentary Practice, p. 453.

311 ibid.

312 ibid, p. 454.

313 PFA, s.2; McGee, Parliamentary Practice, p. 444.

314 PFA, s.2.

${ }^{315}$ McGee, Parliamentary Practice, p. 444.
} 
appropriations. ${ }^{316}$ Each Vote has a responsible Minister or Ministers that are in charge of it. ${ }^{317}$ The Minister or Ministers are responsible to Parliament for the use of the appropriations contained in the Vote. ${ }^{318}$ For offices of Parliament the responsible Minister is the Speaker. ${ }^{319}$ Ministers may hold responsibility for more than one Vote. Each Vote is administered by one department or office of Parliament. ${ }^{320}$ Proposed appropriations for offices of Parliament are considered and recommended by the House, specifically the Officers of Parliament Committee, before they are included in an Appropriation Bill. ${ }^{321}$

Appropriations are tightly specified to ensure Parliament is aware of what it is authorising. Appropriations must be one of six types that reflect different forms of expenses and capital expenditure with separate appropriations required for each category under each type. ${ }^{322}$ The six appropriations types are: output expenses, benefits or other unrequited expenses, other expenses, capital expenditure, and expenses and capital expenditure incurred by each intelligence and security department. ${ }^{323}$ Output expenses are usually for a single class of outputs that are a grouping of similar outputs. ${ }^{324}$ Dissimilar output expenses may be grouped together to form multi-class output expenses but their usage requires explanation. ${ }^{325}$ Appropriations are defined as departmental or non-departmental to limit who receives the money. ${ }^{326}$ Appropriations allow for the incurring of expenses and capital expenditure up to a maximum amount. ${ }^{327}$ There is the exception that departments are able to incur output expenses up to the amount of revenue that they expect to receive from that class of outputs from parties other than the Crown. ${ }^{328}$ However, the usage of this provision must be specified in an Appropriation Act and have the approval of the Minister of Finance. The ability to incur expenses and capital expenditure is limited by the scope of the appropriation and cannot be used for any other purpose. ${ }^{329}$ Lastly, appropriations are limited by the time period that they can be used for. Most appropriations are for one year and lapse at the end of the financial

\footnotetext{
316 Treasury, 'Putting it Together', p. 17; PFA, s.2.

317 ibid.

${ }^{318}$ Treasury, 'A Guide to the Public Finance Act', p. 15.

319 PFA, s. 2 .

320 ibid.

${ }^{321}$ PFA, s.26E; S.O.392.

${ }^{322}$ McGee, Parliamentary Practice, p. 459; PFA, s.7.

${ }^{323}$ PFA, s.7.

324 Treasury, 'Putting it Together', p. 32; PFA, s.2.

325 PFA, s.7.

${ }^{326}$ Treasury, 'Putting it Together', p. 32; PFA, s.7.

${ }^{327}$ PFA, s.8.

328 PFA, s. 21.

${ }^{329}$ PFA, s.9.
} 
year. ${ }^{330}$ Parliament can approve appropriations for any number of years but multi-year appropriations ensure that a standard is available for appropriations longer than one year. ${ }^{331}$ Multi-year appropriations can be for up to five years. ${ }^{332}$ The PFA provides departments with flexibility to manage their assets and capital expenditure with provisions to ensure parliamentary control and scrutiny. ${ }^{333}$

\section{Permanent Appropriations}

Permanent appropriations provide parliamentary authority to spend public money outside of the supply process. Permanent appropriations or permanent legislative authorities provide authority for the spending of public money through legislation other than an Appropriation Act. ${ }^{334}$ Permanent appropriations are primarily used for two purposes: to show independence from government, including the Auditor-General's salary, ${ }^{335}$ and for the servicing and repayment of debt to provide reassurance to those lending money to the Crown. ${ }^{336}$ Permanent appropriations continue in operation until they are repealed by Parliament. ${ }^{337}$ The legislation providing parliamentary authority for a permanent appropriation generally imposes a limit on the scope but not the amount of spending. ${ }^{338}$ The PFA allows for expenses and capital expenditure to be incurred as a part of a permanent appropriation that otherwise only provide for the payment of public money. Permanent appropriations must be managed and accounted for as though they were incurred under an Appropriation Act. ${ }^{339}$ The information supporting the Estimates includes for each proposed category of expenses or capital expenditure to be incurred under a permanent appropriation the information required for appropriations in the Estimates, except the amount is a forecast, and the authority for each expense or capital expenditure. ${ }^{340}$

Emergency, Excess and Transferring Appropriations

\footnotetext{
330 Treasury, 'Putting it Together', p. 34; PFA, s.10.

${ }^{331} \mathrm{McGee}$, Parliamentary Practice, p. 457.

332 PFA, s. 10.

${ }^{333}$ PFA, s.22-s.24; Treasury, 'A Guide to the Public Finance Act', pp. 22-23.

334 Treasury, 'A Guide to the Public Finance Act', p. 23.

335 New Zealand Parliament, 'Public Audit Act 2001', 1 July 2012, http://www.legislation.govt.nz/act/public/2001/0010/latest/DLM88541.html (21 July 2012), Schedule 3.

${ }^{336}$ McGee, Parliamentary Practice, p. 456.

337 Treasury, 'Putting it Together', p. 35.

338 ibid.

${ }^{339}$ PFA, s. 11.

340 PFA, s. 15 .
} 
The government has some flexibility with appropriations that is balanced by reporting requirements that ensure parliamentary scrutiny. The Minister of Finance may approve the incurring of expenses and capital expenditure to meet a declared emergency or disaster without an appropriation. ${ }^{341}$ The Minister is not limited in the amount they can approve. ${ }^{342}$ The expenses and capital expenditure incurred must be included in the annual financial statements of the government and in an Appropriation Bill for confirmation from Parliament. ${ }^{343}$ The government is allowed to make limited transfers between output expense appropriations, and incur expenses and capital expenditure to a limited extent in excess of the level appropriated during the last three months of the financial year. Any changes made using either provision must be included in an Appropriation Bill for confirmation from Parliament. ${ }^{344}$ A statement of excess expenses and capital expenditure must be included in the annual financial statements of the government and the department administering the Vote that contains the appropriation. ${ }^{345}$ The requirement for the government to get confirmation from Parliament does not affect the validity of the expenditure. ${ }^{346}$ The confirmation requirement ensures that the expenditure can be scrutinised by Parliament. ${ }^{347}$

\section{Unappropriated Expenditure}

Parliament retrospectively provides approval for the expenditure of public money. Parliament may want to legalise expenses or capital expenditure that were incurred without an appropriation or other authority. ${ }^{348}$ The desire to retrospectively grant approval may come from recognising that public money was spent in good faith and that there are obligations entered into that must be met through legalised expenditure. ${ }^{349}$ Unappropriated expenditure occurs when expenses or capital expenditure are incurred without an appropriation or the amount incurred is in excess of an appropriation. ${ }^{350}$ Parliament may validate unappropriated expenses or capital expenditure in an Appropriation Act. The Minister of Finance must provide a report to the House when validation is requested in an Appropriation Bill. ${ }^{351} \mathrm{~A}$ statement detailing any unappropriated expenditure must be included in the financial

\footnotetext{
${ }^{341}$ PFA, s.25.

342 Treasury, 'A Guide to the Public Finance Act', p. 26.

${ }^{343}$ PFA, s. 25.

${ }^{344}$ McGee, Parliamentary Practice, p. 463; PFA, s.26A and s.26B.

345 ibid; PFA, s.26D.

346 ibid, p. 491; PFA, s.25, s.26A and s.26B.

347 Treasury, 'A Guide to the Public Finance Act', p. 26.

${ }^{348}$ McGee, Parliamentary Practice, p. 463.

349 ibid.

350 Treasury, 'Putting it Together', p. 81; PFA, s.26D.

${ }^{351}$ PFA, s.26C.
} 
statements for the financial year of both the government and the department that administers the Vote. ${ }^{352}$ Without validation the unappropriated expenses and capital expenditure remain unlawful. ${ }^{353}$

\section{Appropriation (Financial Review) Bill}

The government is able to get validation and confirmation for expenditure after the financial year has ended through an Appropriation (Financial Review) Bill. Appropriation (Financial Review) Bills are 'An Appropriation Bill containing provisions solely concerned with the confirming or validating of expenditure incurred in respect of any previous year' ${ }^{354}$ They allow the government to get the required confirmation in an Appropriation Bill for expenses and capital expenditure incurred in an emergency and in excess of existing appropriations as well as transfers between appropriations within a Vote. ${ }^{355}$ The Appropriation (Financial Review) Bill also allows the government to get unlawful expenditure, expenses or capital expenditure incurred without an appropriation or other authority, validated by Parliament. ${ }^{356}$ Unlawful expenditure is occasionally validated in other legislation. ${ }^{357}$

\section{Budget and Estimates Documentation}

\section{The Estimates}

The Estimates and the other supporting information contain the details required for appropriations contained in an Appropriation Bill. The government specifies its appropriations request from Parliament in the Estimates. ${ }^{358}$ Appropriation Bills only state the name and the amount of each appropriation. Parliament approves appropriations in an Appropriation Bill with reference to the information contained in the Estimates and other supporting information. ${ }^{359}$ The Minister of Finance presents the Estimates and other supporting information on the same day as the presentation of the Appropriation (Estimates) Bill and no later than after the delivery of the Budget. ${ }^{360}$ The Estimates must contain for each appropriation: the Vote that each appropriation relates to, the responsible Minister or

\footnotetext{
352 PFA, s.26D.

${ }^{353}$ McGee, Parliamentary Practice, p. 463.

${ }^{354}$ S.O.342.

${ }^{355}$ McGee, Parliamentary Practice, p. 491; PFA, s.25, s.26B and s.26A.

356 ibid; PFA, s.26C.

357 ibid, p. 492.

358 Treasury, 'Putting it Together', p. 28.

${ }^{359}$ McGee, Parliamentary Practice, p. 480.

${ }^{360}$ PFA, s. 13 .
} 
Ministers, the department that will administer the Vote containing the appropriation, the appropriation type, scope and period (if greater than one year) and the amount appropriated. The responsible Minister for each department must be identified and the projected balance of net assets for the department at the end of the financial year. ${ }^{361}$ The format of the Estimates is determined predominantly by the Minister of Finance with the information requirements having a significant influence. ${ }^{362}$ The Minister must consult the House on significant proposed changes to the format or content of the Estimates, supporting information, or Supplementary Estimates before they can come into effect. Proposed changes are submitted to the Speaker who presents them to the House. ${ }^{363}$ The House refers the proposed changes to the FEC that subsequently passes its own consideration and that of the other select committees to the Minister. ${ }^{364}$ The Minister must consider any comments from the Speaker or select committees. ${ }^{365}$

\section{Information Supporting the Estimates}

Most of the information needed to scrutinise government expenditure is in the information supporting the Estimates. The information supporting the Estimates includes for each appropriation: a short description including its intended impacts, outcomes or objectives, the performance measures and forecast standards to be achieved for each class of outputs, the forecast expenses for each class of output in a multi-class output expense appropriation, and the amount voted and the estimated amount actually spent for each appropriation in the previous financial year. ${ }^{366}$ The supporting information contains for each Vote: the voted and estimated actual expenses and capital expenditure for the previous year, the actual expenses and capital expenditure for the four years before the previous year for the total of each appropriation type and a summary of the financial activity for each Vote that includes the budgeted and estimated actual figures for the previous year. ${ }^{367}$ The Minister of Finance may include with the Estimates or the supporting information any additional information considered necessary or desirable. ${ }^{368}$

\footnotetext{
${ }^{361}$ PFA, s. 14.

${ }^{362}$ McGee, Parliamentary Practice, p. 474.

${ }^{363}$ PFA, s. 18.

${ }^{364}$ McGee, Parliamentary Practice, p. 474.

365 PFA, s. 18.

366 PFA, s. 15

367 ibid.

${ }^{368}$ PFA, s.14-s. 15
} 


\section{Statements of Intent}

Statements of intent provide information on department's and offices of Parliament's future operating intentions. ${ }^{369}$ Statements of intent describe the 'expected contribution to the government's outcomes and priorities over the medium term (three to five years) ${ }^{370}$ They include forecast financial statements and statements of forecast service performance for the current financial year. ${ }^{371}$ Forecast performance information allows for the assessment of actual performance and contribution to outcomes. ${ }^{372}$ Statements of intent include statements of responsibility from the chief executive, chief financial officer and the responsible Minister. ${ }^{373}$ Statements of intent for offices of Parliament have adjusted requirements to reflect that they are responsible to the House and not the government. ${ }^{374}$ Statements of intent for departments and offices of Parliament must be presented on the same day as the Budget. ${ }^{375}$ Crown entities must also present statements of intent. ${ }^{376}$ The statements of intent for Crown entities also contain Budget and output information. ${ }^{377}$ State enterprises (SOEs) present statements of corporate intent. ${ }^{378}$ Departmental output plans, that state the outputs supplied by the department and standards used to measure the departments performance, are a further document used during the Estimates examination. ${ }^{379}$

\section{Supplementary Estimates}

The government can modify the appropriations and Estimates in the main Appropriation (Estimates) Bill with supplementary appropriations and Estimates. Although the main Appropriation Bill and the Estimates serve as the primary authority for incurring expenses and capital expenditure changes will be required during the financial year. ${ }^{380}$ Changes could be necessary because of new Cabinet decisions and more up to date spending forecasts than those used to produce the Estimates. ${ }^{381}$ Parliament authorises the changes wanted by the

\footnotetext{
369 PFA, s.38 and s.45F.

370 Treasury, 'Putting it Together', p. 28.

${ }^{371}$ PFA, s.41.

372 Treasury, 'Putting it Together', p. 28.

${ }^{373}$ PFA, s.38 and s.42.

${ }^{374}$ PFA, s.45F and s.45G; Treasury, 'A Guide to the Public Finance Act', p. 66.

375 PFA, s. 39.

${ }^{376}$ CEA, s. 149 .

377 Treasury, 'Putting it Together', p. 74.

${ }^{378}$ New Zealand Parliament, 'State-Owned Enterprises Act 1986', 30 August 2013, http://www.legislation.govt.nz/act/public/1986/0124/latest/DLM97377.html (28 September 2013). s.14 and s.17.

${ }^{379}$ McGee, Parliamentary Practice, p. 481

380 ibid, p. 489.

381 Treasury, 'Putting it Together', p. 27.
} 
government with supplementary appropriations. ${ }^{382}$ Supplementary appropriations generally only make technical accounting adjustments with select committees expecting to have their attention drawn to changes in government policy. ${ }^{383}$ Supplementary Estimates must state all changes to the information contained in the main Estimates that result from the Appropriation (Supplementary Estimates) Bill. ${ }^{384}$ The Minister of Finance must introduce Supplementary Estimates on the same day as the Appropriation (Supplementary Estimates) Bill. ${ }^{385}$

\section{Standard Estimates Questionnaire}

The standard estimates questionnaire is an important information source for select committees' examination of the Estimates. The standard estimates questionnaire asks for information which supplements that contained in the Estimates and other supporting information. The FEC produces the questionnaire and receives advice from the AuditorGeneral on its form. ${ }^{386}$ The questionnaire suggests to select committees what information they may want to obtain from their examination. ${ }^{387}$ Select committees may supplement the standard questionnaire with additional questions. Members may ask further written questions of Ministers and departments prior to the oral hearing but the select committee must approve of their usage to be formally included in the Estimates process. ${ }^{388}$ The sending off of the questionnaire to Vote Ministers is the first step in the Estimates examination. Ministers receive the standard questionnaire in respect of each Vote six weeks out from the Budget and are requested to respond to the committee soon after the delivery of the Budget statement and before the Vote's examination. ${ }^{389}$ The questionnaire is designed to not be burdensome on the Minister or department.

\section{Fiscal Responsibility Documents}

The Minister of Finance must present to the House a number of fiscal responsibility documents. The fiscal responsibility documents are tied together with each other and the principles of responsible fiscal management creating a framework to scrutinise government fiscal and economic management. Economic and fiscal updates provide economic and fiscal

\footnotetext{
382 McGee, Parliamentary Practice, p. 489.

383 ibid.

${ }^{384}$ Treasury, 'A Guide to the Public Finance Act', p. 14; PFA, s. 17.

385 PFA, s. 16.

${ }^{386}$ McGee, Parliamentary Practice, p. 481.

387 ibid, p. 452.

388 ibid, p. 481.

389 ibid.
} 
forecasts from the Treasury for the current and next two financial years. ${ }^{390}$ An economic and fiscal update must be presented in November or December. ${ }^{391}$ The budget policy statement states for the upcoming Budget the broad strategic priorities guiding its preparation and explains any changes to fiscal objectives or intentions. It must be presented by $31 \mathrm{March}$ in the financial year prior to which it relates. ${ }^{392}$ The fiscal strategy report sets out the government's long-term objectives and its short-term intentions across five fiscal variables and how they are consistent with the principles of responsible fiscal management. ${ }^{393}$ The fiscal strategy report and an economic and fiscal update must be presented on Budget day and no later than immediately after the Budget has been delivered. ${ }^{394}$ An economic and fiscal update must be presented just before a general election, usually between 20 to 30 working days prior. ${ }^{395}$ A statement on the long-term fiscal position is prepared for the House every four years by the Treasury. ${ }^{396}$ The statement is referred to the FEC. ${ }^{397}$ All documents are prepared in accordance with generally accepted accounting practice (GAAP). ${ }^{398}$

\section{Financial Statements and Accounting}

The following section describes the financial reporting documents entities are required to present to the House. GAAP determines how financial information must be prepared and presented to the House. The government must prepare its financial statements in accordance GAAP. ${ }^{399}$ GAAP means any applicable finance reporting standards set by the Accounting Standards Review Board. ${ }^{400}$ Where no provision is made in financial reporting standards accounting policies must be appropriate to the Crown, department, office of Parliament or Crown entity and have authoritative support within the New Zealand accounting profession. ${ }^{401}$ The Accounting Standards Review Board, an independent Crown entity, sets financial reporting standards independently of the government. ${ }^{402}$ The House is able to

\footnotetext{
${ }^{390}$ PFA, s.26O, s.26P and s.26Q.

${ }^{391}$ PFA, s.26S.

392 PFA, s.26M.

393 PFA, s.26J and s.26K.

${ }^{394}$ PFA, s.26I and s.26O.

395 PFA, s.26T.

${ }^{396}$ PFA, s.26N.

397 S.O.331.

${ }^{398}$ PFA, s.26H.

${ }^{399}$ McGee, Parliamentary Practice, p. 499.

400 ibid; PFA, s.2.

401 PFA, s.2.

402 New Zealand Parliament, 'Financial Reporting Act 1993', 14 September 2013, http://www.legislation.govt.nz/act/public/1993/0106/latest/DLM323598.html (28 September 2013), s.24-s.26; Treasury, 'Putting it Together', p. 13.
} 
disallow or amend reporting standards set by the Accounting Standards Review Board. ${ }^{403}$ The government's accounting practices are based on internationally accepted standards. GAAP is aligned with international financial reporting standards (IFRS) resulting in 'harmonisation' between New Zealand's financial reporting standards and best international practice. ${ }^{404}$ The usage of GAAP for the government's financial statements means that their accounts are prepared and audited to the same standards as the private sector. ${ }^{405}$

Accrual accounting rather than cash accounting is used for the government's financial statements. Accrual accounting is more accurate than cash accounting because it 'measures expenses when incurred and revenue when earned'. ${ }^{406}$ Accrual accounting provides more accurate information because it 'captures the full cost of resources used to produce outputs, it provides better information to support costing, purchase and ownership decisions than cash accounting provides'. ${ }^{407}$ It is also 'less subject to manipulation'. ${ }^{408}$ Information on cash-flows is still important and is presented along with the accrual information in financial statements. Accrual accounting allows the government and government entities to accurately present their financial position on a balance sheet showing their assets and liabilities. ${ }^{409}$

\section{Departments and Offices of Parliament}

Departments and offices of Parliament produce annual reports. They are produced after the financial year has ended. ${ }^{410}$ Annual reports contain information on operations and performance, a statement of service performance, annual financial statements, an audit report and a statement of responsibility. ${ }^{411}$ The statement of service performance describes the performance in delivering outputs compared with that forecast in the Statement of Intent including a comparison of the forecast and the actual output expenses incurred. ${ }^{412}$ The financial statements contain the earlier forecast financial statements, and a statement of actual expenses and capital expenditure incurred against appropriations administered by the department, a statement and explanation of unappropriated expenses or capital expenditure incurred and any other information needed to fairly reflect its financial operations or

\footnotetext{
403 ibid, s.33.

404 Treasury, 'Putting it Together', p. 13.

405 Palmer and Palmer, Bridled Power, p. 125.

406 Treasury, 'Putting it Together', p. 12.

407 ibid.

408 Treasury, 'A Guide to the Public Finance Act', p. 7.

409 Treasury, 'Putting it Together', p. 12.

${ }^{410}$ PFA, s.43 and s.45F.

411 PFA, s.45.

${ }^{412}$ McGee, Parliamentary Practice, p. 503; PFA, s.45A.
} 
position. ${ }^{413}$ The statement of service performance and the financial statements are prepared in accordance with generally accepted accounting practice (GAAP). ${ }^{414}$ The chief executive and chief financial officer must sign a statement of responsibility. ${ }^{415}$ The Auditor-General audits the financial statements and the statement of service performance. An audit report is presented within three months after the end of the financial year. Departments' full annual reports are also referred to the Auditor-General for review before providing the audit report. ${ }^{416}$ The responsible Minister presents the annual report to the House. ${ }^{417}$

\section{Crown entities, SOEs and other public organisations}

Crown entities, SOEs and other public organisations must also produce annual reports. Crown entities produce annual reports that contain statements of service performance, with the exception of schools and tertiary education institutions, and annual financial statements at the end of the financial year. ${ }^{418}$ Crown entities' financial statements are audited by the Auditor-General who produces an audit opinion. ${ }^{419}$ The responsible minister presents the annual report to the House. ${ }^{420}$ SOEs present annual reports containing information of the operations of the enterprise and its subsidiaries as well as annual financial statements. ${ }^{421}$ The annual report is expected to compare the SOEs performance with its earlier statement of corporate intent. ${ }^{422}$ Other public organisations also prepare annual reports that are presented to the House. Several public organisations listed in schedule four of the PFA must present annual reports to the House meeting the conditions set in the Crown Entities Act 2004 (CEA). ${ }^{423}$ A number of other public organisations are required by specific legislation to prepare annual reports for the House. ${ }^{424}$

\section{Annual Financial Statements of the Government}

\footnotetext{
413 PFA, s.45B.

${ }^{414}$ PFA, s.45A and s.45B.

${ }^{415}$ PFA, s.45C.

${ }^{416}$ PFA, s.45D.

${ }^{417}$ PFA, s. 44. s.154.

${ }^{419}$ CEA, s. 156.

${ }^{420}$ McGee, Parliamentary Practice, p. 503.

${ }^{421}$ State Owned Enterprises Act 1986, s.15.

${ }^{422}$ McGee, Parliamentary Practice, p. 503.

${ }^{423}$ PFA, Schedule 3.

${ }^{424}$ McGee, Parliamentary Practice, p. 503.
}

${ }^{418}$ McGee, Parliamentary Practice, p. 501; New Zealand Parliament, 'Crown Entities Act 2004', 8 August 2013, http://www.legislation.govt.nz/act/public/2004/0115/latest/DLM329631.html (28 September 2013), s.150- 
Annual financial statements are prepared for the whole of government. The Treasury produces annual consolidated 'Financial Statements of the Government of New Zealand' that include the entire government reporting entity. ${ }^{425}$ The government reporting entity includes departments, offices of Parliament, mixed ownership model companies, schedule four organisations, SOEs, Crown entities, and the Reserve Bank of New Zealand. ${ }^{426}$ The annual financial statements include information in accordance with GAAP, additional information to that, and the earlier forecast financial statements. ${ }^{427}$ The financial statements of the government are audited by the Auditor-General who produces an audit report. ${ }^{428}$ The Minister of Finance and the Secretary of the Treasury must sign statements of responsibility. ${ }^{429}$ The Minister presents to the House the annual financial statements, the audit report and the statement of responsibility. ${ }^{430}$ The statements are presented to the House approximately three months after the financial year has ended. ${ }^{431}$ The government must also produce monthly financial statements. ${ }^{432}$ Monthly financial statements are not presented to the House but they are publically available. ${ }^{433}$

\section{Reports on non-departmental appropriations}

The financial review process includes the consideration of reports on non-departmental appropriations. The reports are produced when an Appropriation Bill states that an appropriation or class of outputs within an appropriation, with expenses or capital expenditure incurred by an entity other than a department or an office of Parliament, is subject to section 32A of the PFA. The report contains a statement of service performance or a statement of results, and a comparison of the actual expenses or capital expenditure incurred with the amount appropriated or forecasted. A statement of service performance is not required when another entity is required to report on it. The Minister responsible for the appropriation or class of output presents the non-departmental appropriations report to the House within three months of the end of the financial year. ${ }^{434}$

\footnotetext{
425 PFA, s. 27 and s.2.

${ }^{426}$ PFA, s.27; Treasury, 'Putting it Together', p. 78.

427 PFA, s.27.

${ }^{428}$ PFA, s. 30 .

429 PFA, s.29.

${ }^{430}$ PFA, s. 31 .

431 ibid.

432 PFA, s.31A.

${ }^{433}$ PFA, s.31B

${ }^{434}$ PFA, s.32A.
} 


\section{Parliamentary Process}

\section{Introduction}

Parliament provides the government with consent to spend public money and reviews government expenditure based on an annual financial cycle. The recurring annual cycle is not a necessity 'it is always a question of legislative choice'. ${ }^{435}$ The annual cycle works around the government's financial year that runs from the $1^{\text {st }}$ of July through to the $30^{\text {th }}$ of June in the following calendar year. ${ }^{436}$ Parliament's financial cycle has two separate distinct processes; the supply process and the financial review process. The supply process involves Parliament granting appropriation or authorisation to the government to spend money to carry on the government in respect of that financial year that is not permanently appropriated. ${ }^{437}$ The financial review process serves as Parliament's post-expenditure examination of government expenditure. It involves the review of: the performance in the previous financial year and current operations of each individual department, office of Parliament, Crown entity, public organisation and SOE, reports on non-departmental appropriations, as well as the annual financial statements of the government. ${ }^{438}$ The following page contains a diagram of the supply and financial review processes. The following section describes the two processes in detail. A summary table of debate lengths and MPs speaking times is included at the end of the section.

\footnotetext{
435 McGee, Parliamentary Practice, p. 445.

${ }^{436}$ PFA, s. 2.

${ }^{437}$ McGee, Parliamentary Practice, p. 470.

438 S.O.339-341.
} 


\section{Figure 3.1: Supply and Financial Review Process Diagram}

November-December: Budget policy statement and economic and fiscal update presented to the House.

February: FEC examination of budget policy statement and economic and fiscal update.

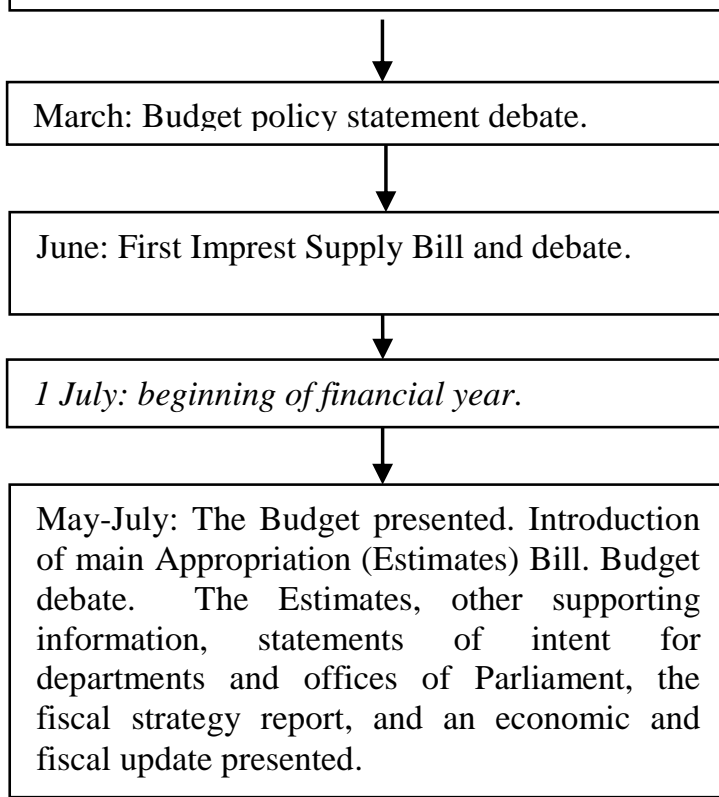

August-September: Select committees examine and report on the Estimate (as allocated by FEC) s. FEC examines and reports on the fiscal strategy report and economic and fiscal update.

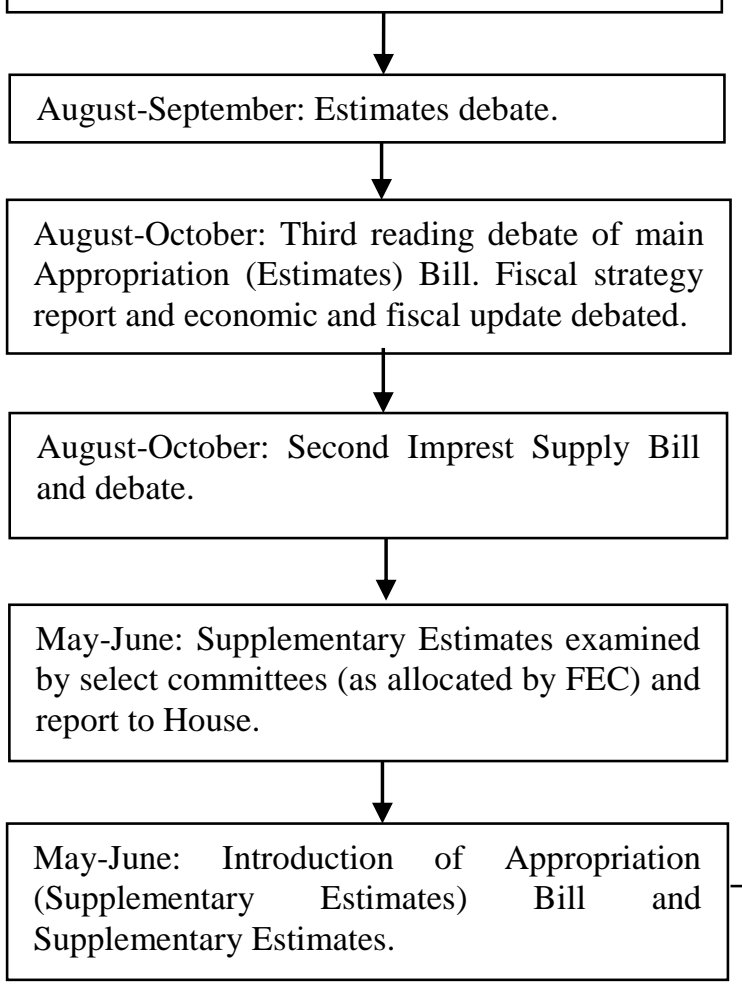

June: Supplementary Estimates debate. Appropriation (Supplementary Estimates) Bill passed.

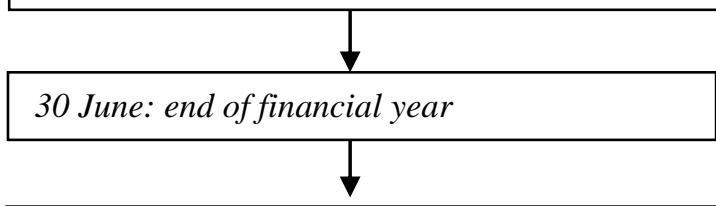

August-September: Non-departmental appropriations reports presented.

September-October: Annual financial statements of the government and audit report presented.

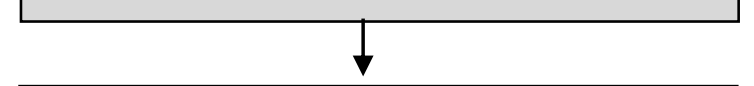

September-October: Annual reports of
$\begin{aligned} & \text { departments and offices of Parliament } \\ & \text { presented. }\end{aligned}$

November-December: Appropriation

(Financial Review) Bill introduced.

November-December: FEC examination of annual financial statements of the government.

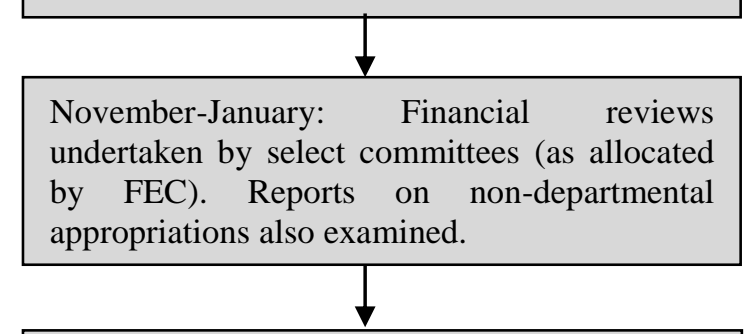

February-March: Financial review debate on financial reviews of departments and offices of Parliament, reports on non-departmental appropriations, and annual financial statements of the government. Appropriation (Financial Review) Bill passed.

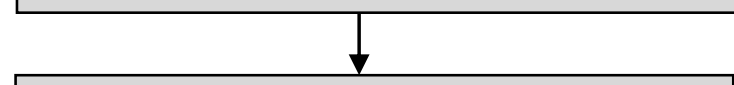

Debate on the financial reviews of Crown entities, SOEs and other public organisations.

Supply process

Financial review process

Source: Office of the Clerk, 'Parliament's Annual

Financial Cycle', June 2012,

http://www.parliament.nz/resource/0000195069 (25 June 2013). 


\section{Supply Process}

\section{Budget Policy Statement and Economic and Fiscal Update}

Parliament's supply process begins in the prior financial year with an economic and fiscal update and the budget policy statement. The budget policy statement and the economic and fiscal update are typically considered together in November or December as the statement is usually ready early. ${ }^{439}$ The budget policy statement and the economic and fiscal update are examined by the FEC. ${ }^{440}$ The Minister of Finance must attend the committee hearing on the budget policy statement if requested. A transcript is made of the hearing and public submissions are requested. The FEC must report back to the House on the budget policy statement within 40 working days. The next general debate after the report has been presented is replaced with one on the statement and the report. The chairperson of the FEC has the right to speak first. ${ }^{441}$ The debate is comprised of 12 speeches from individual members of up to ten minutes with the debate running for up to two hours. ${ }^{442}$ All debate must be relevant to the question before the House. ${ }^{443}$ For the debate on the budget policy statement MPs must speak to the statement and the report. ${ }^{444}$

\section{First Imprest Supply Bill}

Imprest supply is granted through an Imprest Supply Act. Imprest supply provides the government with interim authority from Parliament to incur expenses and capital expenditure for any purpose before an appropriation has been approved. The condition is that all spending must later be contained as appropriations in an Appropriation Act for the same financial year. ${ }^{445}$ The first Imprest Supply Bill is introduced and passed before the financial year has begun. The bill provides imprest supply from the beginning of the financial year until the main Appropriations Bill has passed. ${ }^{446}$ The first Imprest Supply Bill is passed at the time as the Appropriation (Supplementary Estimates) Bill for the previous year. ${ }^{447}$ The debates on the second reading of an Appropriation (Supplementary Estimates) Bill and an Imprest Supply

\footnotetext{
${ }^{439}$ McGee, Parliamentary Practice, p. 472; Treasury, 'Putting it Together', p. 26.

${ }^{440}$ S.O.327 and S.O.331.

${ }^{441}$ S.O.327.

442 S.O. Appendix A.

${ }^{443}$ S.O.108.

${ }^{444}$ McGee, Parliamentary Practice, p. 472.

445 Treasury, 'A Guide to the Public Finance Act', p. 14; Treasury, 'Putting it Together', p. 82

446 Treasury, 'Putting it Together', p. 82.

447 ibid.
} 
Bill may be combined. ${ }^{448}$ The two debates may be combined because both must be passed by the end of the current financial year. ${ }^{449}$

The House has a special process for Imprest Supply Bills. The government may introduce and proceed with an Imprest Supply Bill at any time provided no debate is interrupted. ${ }^{450}$ They may pass through all required stages on the same day in normal sitting hours. There is no debate at the first reading. ${ }^{451}$ Imprest Supply Bills, and Appropriation Bills themselves, are not referred to a select committee. ${ }^{452}$ The House debates the Imprest Supply Bill at the second reading. There are 'virtually no limitations' on relevancy in the debate. ${ }^{453}$ Members may propose amendments relating to any matter concerning public affairs and are not required to be strictly relevant. ${ }^{454}$ A question of confidence in the government may be raised. ${ }^{455}$ Members may speak for ten minutes and the whole debate is three hours. ${ }^{456}$ Following the second reading the House moves immediately to the third reading unless the Minister in charge of the bill requires the House to go into committee to consider an amendment. There is no debate at the third reading. ${ }^{457}$

\section{The Budget Debate}

The Budget containing the main Appropriations Bill is presented to the House at 2pm on a Thursday, usually in May, with the day notified in advance by the government. ${ }^{458}$ The Minister of Finance delivers the Budget statement, a prepared speech explaining the government's economic and fiscal policies, at the second reading. ${ }^{459}$ The Minister has unlimited speaking time. ${ }^{460}$ After the Budget Statement, or alternatively at any time prior on the same day, the Minister of Finance presents to the House a copy of the Budget Statement, the Estimates and other supporting information, ${ }^{461}$ the statements of intent for departments and office of Parliament, ${ }^{462}$ the fiscal strategy report, ${ }^{463}$ and an economic and fiscal update. ${ }^{464}$

\footnotetext{
448 S.O.337.

${ }^{449}$ McGee, Parliamentary Practice, pp. 476-477.

${ }^{450}$ S.O. 280 .

451 S.O.326.

452 S.O.284.

${ }^{453}$ McGee, Parliamentary Practice, p. 476.

${ }^{454}$ S.O.326.

${ }^{455}$ McGee, Parliamentary Practice, p. 476

${ }^{456}$ S.O. Appendix A.

${ }^{457}$ S.O.326.

${ }^{458}$ McGee, Parliamentary Practice, p. 477; S.O.328.

459 ibid, p. 478; S.O.328.

${ }^{460}$ S.O. Appendix A.

461 PFA, s.13.

462 PFA, s.39.

${ }^{463}$ PFA, s.26I.
} 
The subsequent Budget debate is started by the opposition's leader or finance spokesperson followed by the other party leaders in order of party size starting with the Prime Minister. Amendments may be proposed relating to any matter of public affairs providing the opportunity to raise a no confidence motion. ${ }^{465}$ The debate goes for 14 hours excluding the Budget statement. Leaders of parties with six or more members speak for 20 minutes. Other members and Ministers speaking in reply may speak for ten minutes. ${ }^{466}$ The debate may conclude with a ten minute reply from the Minister of Finance. ${ }^{467}$

\section{Select Committee Examination of the Estimates}

The Estimates and other Budget documentation are referred to select committees for consideration. The Estimates are referred to the FEC that allocates the task of examining the Estimates to itself and the other select committees. Votes are allocated to the select committee that is responsible for the appropriate subject area. The FEC may break up a Vote and refer its appropriations to multiple select committees. ${ }^{468}$ The ability is used infrequently but it does allow for a Minister's appropriations to be considered together. Oral hearings are subsequently held where members question the Minister in charge of the Vote and the chief executive of the department with the assistance of officials. Hearings begin with the Minister taking the opportunity to make a short statement. The hearing is conducted as the chairperson directs with the committees' approval. ${ }^{469}$ The chairperson ensures that questions are relevant and that the information sought is for the hearings purpose. ${ }^{470}$ Members can request further information in writing on issues raised during the hearing. ${ }^{471}$ The hearings are generally open to the public, although they can be in private. ${ }^{472}$ Select committees receive assistance from the Auditor-General including a written and oral briefing if requested. ${ }^{473}$ Select committees following the hearing determine whether they can recommend that the appropriations in the Vote be accepted and may recommend changes. ${ }^{474} \mathrm{~A}$ report is produced for the House that summarise the responses to the questionnaire, other written questions and the oral

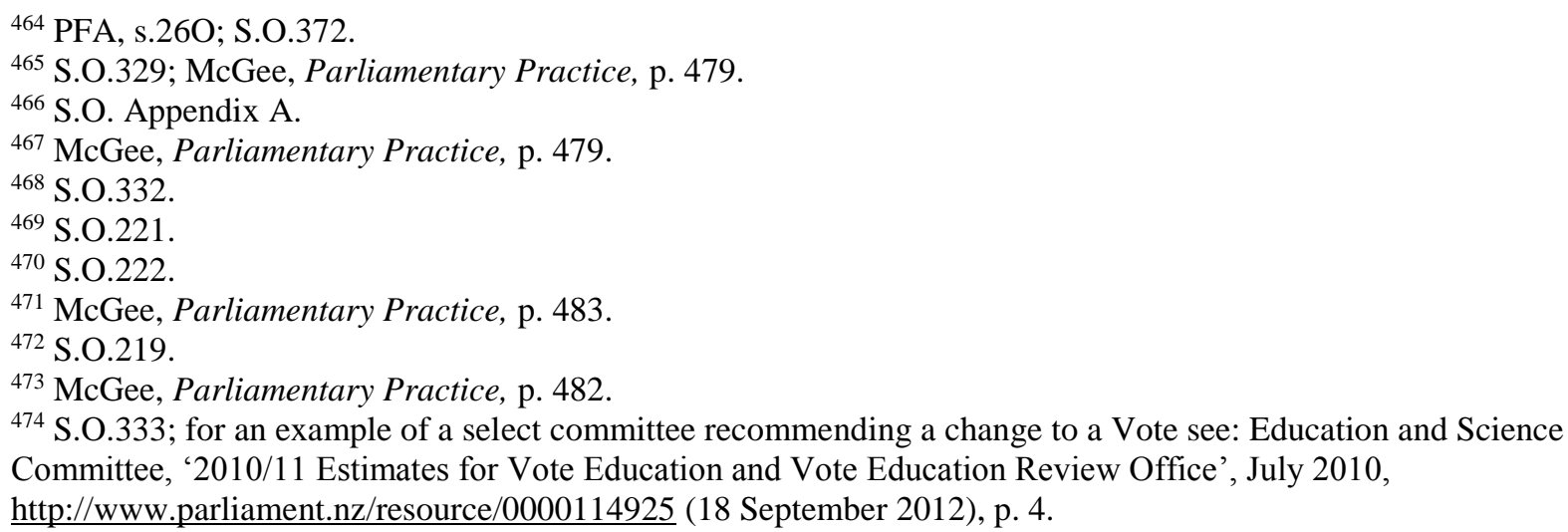


examination. ${ }^{475}$ Reports may include minority views to reflect differing opinions of members. ${ }^{476}$ Select committees must report back within two months of the delivery of the Budget. ${ }^{477}$ The FEC also considers the fiscal strategy report and the economic and fiscal update and reports to the House on both documents within two months of the delivery of the Budget. $^{478}$

\section{Estimates Debate}

The Estimates debate held, at the committee stage of the main Appropriation Bill, is where the House considers the appropriations requested by the government in each Vote. The House debates the Votes in order on the question that each stand part. ${ }^{479}$ The Business Committee may determine the order that Votes are considered and how long will be spent on each. ${ }^{480}$ However, the task is allocated to party whips allowing for a speaking list that distributes the time between parties and lets them decide which Votes they will debate. ${ }^{481}$ Which Votes are available to debate and how long will be spent on the debate that day is determined by the government. ${ }^{482}$ At the conclusion of the debate any remaining Votes and amendments proposed by the Minister of Finance that have not yet been considered are combined into a single question. There is no debate on the question. ${ }^{483}$ A Minister, usually the responsible Minister, is available to answer questions with officials present to assist. ${ }^{484}$ The Estimates debate is restricted to the expenditure plans in the Budget documentation. ${ }^{485}$ MPs may propose a change to a Vote. ${ }^{486}$ The FEC may examine adjustments proposed by the government. ${ }^{487}$ The Estimates debate is eight hours long. Ministers in charge of the Vote under consideration may deliver multiple five minute speeches but normally no more than two consecutive speeches. Other members may make two five minute speeches on each Vote. $^{488}$

\footnotetext{
${ }^{475}$ McGee, Parliamentary Practice, p. 483.

476 S.O. 242.

477 S.O.333.

478 S.O.330.

479 S.O.334

${ }^{480}$ S.O.77.

${ }^{481}$ McGee, Parliamentary Practice, p. 485.

482 S.O.346

${ }^{483}$ S.O.334.

${ }^{484}$ McGee, Parliamentary Practice, p. 485.

485 ibid, p. 486.

486 S.O.334.

${ }^{487}$ McGee, Parliamentary Practice, p. 487.

${ }^{488}$ S.O. Appendix A.
} 


\section{Appropriation Bill Debate}

The main Appropriation Bill is debated at its third reading. Members' debate must be relevant. The debate may include reference to the fiscal strategy report, the economic and fiscal update presented with the Budget, and the FEC's reports on each document. ${ }^{489}$ The third reading debate goes for three hours and members speak for ten minutes. ${ }^{490}$ The debate on the third reading must be completed within three months of the delivery of the Budget. ${ }^{491}$ Given that the Budget must be presented to the House by 31 July the main Appropriations Bill must be passed by 31 October at the latest. The bill is passed much earlier in practice due to the Budget usually being delivered in May. ${ }^{492}$

\section{Second Imprest Supply Bill}

A second Imprest Supply Bill is passed at the same time as the main Appropriations Bill. The passing of the main Appropriations Bill ends the appropriation authority provided by the first Imprest Supply Act. ${ }^{493}$ However, the main Appropriation Act provides parliamentary authority with most of the financial year yet to occur. Supplementary Estimates with new and modified appropriations are presented later. The second Imprest Supply Bill provides parliamentary authority to address spending issues that will arise in the meantime. The authority provided by the second Imprest Supply Act ends when the Appropriation (Supplementary Estimates) Bill is passed. ${ }^{494}$ Expenses and capital expenditure incurred under the second Imprest Supply Bill is later appropriated in the Appropriation (Supplementary Estimates) Bill. ${ }^{495}$ The need to pass the second Imprest Supply Bill at the same time as the main Appropriation (Estimates) Bill is facilitated by the ability to combine the second and third reading debates respectively. ${ }^{496}$ Further Imprest Supply Bills may be introduced if necessary. 497

\section{Supplementary Estimates}

The Appropriation (Supplementary Estimates) Bill and the Supplementary Estimates are examined by Parliament late in the financial year. The bill may be introduced at any time

\footnotetext{
489 S.O.335.

490 S.O. Appendix A.

${ }^{491}$ S.O.335

492 McGee, Parliamentary Practice, p. 488.

493 ibid.

494 ibid.

495 Treasury, 'A Guide to the Public Finance Act', p. 15.

496 S.O.335.

${ }^{497}$ McGee, Parliamentary Practice, p. 489.
} 
provided no debate is interrupted. ${ }^{498}$ The Appropriation (Supplementary Estimates) Bill is generally introduced on the same day as the Budget for the next financial year. ${ }^{499}$ There is no debate at the first reading. ${ }^{500}$ The Supplementary Estimates are referred to the FEC who may examine a Vote itself or refer it to another select committee for examination. ${ }^{501}$ The committee cannot split up a Vote in the Supplementary Estimates examination like it can with the main Estimates. ${ }^{502}$ There is no set report time. However, the Bill must be passed before 30 June, the end of the financial year, providing select committees with little time to consider the Supplementary Estimates. ${ }^{503}$ As a result the FEC frequently examines all Supplementary Estimates itself. ${ }^{504}$ The FEC relies on the explanations of Treasury officials, as well as officials from departments and Ministers, especially the Minister of Finance, when required. ${ }^{505}$ Select committees determine whether they can recommend that the appropriations in respect of the Vote be accepted and they can recommend changes. ${ }^{506}$

The House debates the Supplementary Estimates following the select committee examination. Supplementary Estimates are debated by the House at the second reading of the Appropriation (Supplementary Estimates) Bill. ${ }^{507}$ It is a three hour debate with each member able to speak for ten minutes. ${ }^{508}$ Members' speeches must be relevant to the bill and address the supplementary appropriations. Since it is the last debate of the financial year members may discuss the policies that the government has sought appropriations for throughout the financial year and the government's financial position. ${ }^{509}$ After the second reading the House immediately goes to the third reading. There are two exceptions; when the Minister wants an amendment considered, or a select committee has recommended a change, the House resolves itself into a Committee of the Whole House to consider the proposals. There is no debate at the third reading. ${ }^{510}$ The government may introduce further Supplementary Estimates. ${ }^{511}$

\section{Financial Review Process}

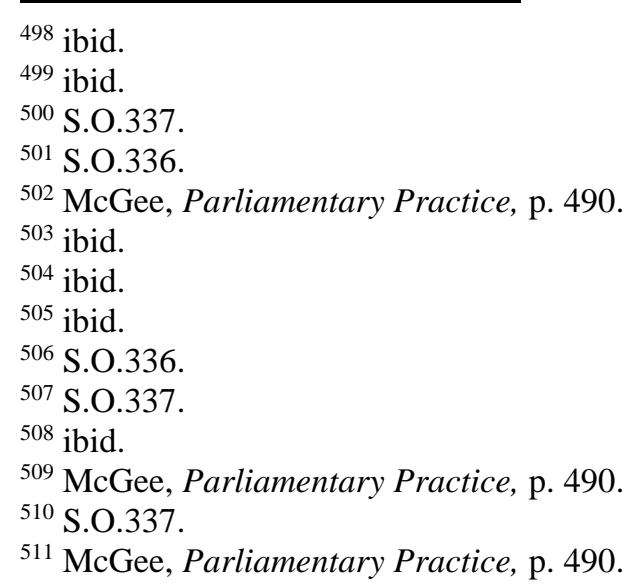




\section{Introduction}

Parliament in the financial review process controls and scrutinises government expenditure after it has occurred. The process starts after the financial year has ended. There are three areas of examination. Firstly, the process involves the undertaking of financial reviews that examine 'the performance in the previous financial year and current operations of each individual department, office of Parliament, Crown entity, public organisation or State enterprise'. ${ }^{512}$ Parliament, mainly its select committees, undertakes the task by reviewing annual reports that include a financial statement. ${ }^{513}$ Secondly, the process has the FEC examine the annual financial statements of the government. ${ }^{514}$ Lastly, reports on nondepartmental appropriations are examined by select committees throughout the year with reports prepared for the House for debate. ${ }^{515}$ The financial review process is largely structured around the consideration of the Appropriation (Financial Review) Bill.

\section{Select Committee Examination}

The financial review process starts with the presentation to the House of the above documents to the House and their referral to select committees. The financial review process begins with the presentation of annual reports to the House. ${ }^{516}$ The annual reports are referred to the FEC that allocates to itself and the other select committees the task of undertaking the financial reviews. ${ }^{517}$ Reports on non-departmental appropriations are also referred to the FEC and allocated in the same fashion. Select Committees are required to report to the House on all non-departmental appropriation reports received within one week of the first sitting day each year. ${ }^{518}$ The FEC is tasked with reporting on the annual financial statements of the government. ${ }^{519}$ The Minister of Finance and the Secretary of the Treasury serve as witnesses for the examination. ${ }^{520}$ The FEC must report to the House within one week of the first sitting day in each year. ${ }^{521}$

The financial review process includes the select committee examination of departments and other entities. The core materials for select committees' examinations are the annual

\footnotetext{
512 S.O.339.

${ }^{513}$ McGee, Parliamentary Practice, p. 510.

514 S.O.340.

${ }^{515}$ S.O.340-341.

${ }^{516}$ McGee, Parliamentary Practice, pp. 510-511.

517 S.O.339.

518 S.O.341

519 S.O.340

${ }^{520}$ McGee, Parliamentary Practice, p. 509.

${ }^{521}$ S.O.340.
} 
report, the Statement of Intent and the output plan of the department or other entity. ${ }^{522}$ Select committees frequently ask for further information before or after the oral examination. Only questions forwarded with the committee's authority are formally part of the review. ${ }^{523}$ The Auditor-General may provide the select committee with an oral briefing if requested. A written briefing is provided unless a select committee requests otherwise. ${ }^{524}$ Witnesses for the committee hearings are the chief executive and senior officials for departments and for other entities the board and management. Although they can be invited Ministers are not expected to appear because financial reviews are for operational matters. Departments or entities may be asked or request themselves that they respond to questions in writing. ${ }^{525}$ Select committees do not carry out full examinations of all entities due to the limited time available. Many reports are based only on the documentation and the Auditor-General's briefing. ${ }^{526}$ Select committees report to the House on the financial reviews for departments and offices of Parliament within one week of the first sitting day in each year. Reports for Crown entities, public organisations or SOEs must be presented within six months of the annual reports' presentation to the House. ${ }^{527}$

\section{Financial Review Debate}

The financial review debate occurs at the committee of the whole stage of the Appropriation (Financial Review) Bill. The bill is generally introduced before the Christmas break. There is no debate at the first or second reading. ${ }^{528}$ The debate allows members to discuss: the annual financial statements of the government and the FEC report, the financial reviews of departments and offices of Parliament, and the reports on non-departmental appropriations. The debate must be held by the end of March. ${ }^{529}$ The government may select the day, which financial reviews are available to debate and how long will be spent on the debate that day. ${ }^{530}$ The debate begins with the noting of the FEC's report on the annual financial statements of the government followed by the financial reviews and non-departmental appropriation reports. ${ }^{531}$ The order and how long is spent on each financial review is determined the same

\footnotetext{
${ }^{522}$ McGee, Parliamentary Practice, p. 511.

523 ibid.

524 ibid.

525 ibid, p. 512.

526 ibid.

${ }^{527}$ S.O.340.

528 S.O.342.

${ }^{529}$ S.O. 343

530 S.O.346.

${ }^{531}$ S.O.343.
} 
way as for the Estimates debate. ${ }^{532}$ The whole debate is four hours. The relevant minister may make multiple five minute speeches but normally not more than two consecutive speeches. Other members may make two five minute speeches for each review. ${ }^{533}$ At the conclusion of the debate any remaining provisions of the bill, and any amendments proposed by the Minister, are put as one question. ${ }^{534}$ Following the adoption of the report of the Committee of the whole House the Bill has its third reading with no debate. ${ }^{535}$

\section{Debate on Financial Review of Crown entities, public organisations and SOEs}

A separate debate is held for the financial reviews of Crown entities, SOEs and public organisations. The government selects the day the debate will be held, advising which financial reviews are available for debate and how long the debate will last that day. ${ }^{536}$ The Speaker ensures that the debate occurs and may interrupt the final sitting day of the financial year to ensure it happens. ${ }^{537}$ The order and how long is spent on each financial review is determined the same way as the Estimates debate. ${ }^{538}$ The debate usually occurs in the April to June period when most select committee reports are available. However, due to the continuous reporting process some will not be available for consideration. ${ }^{539}$ On the government's chosen day the debate on the financial reviews of Crown entities, public organisations, and SOEs is set down as a government order of the day in the charge of a Minister. The debate is held in a committee of the whole House and examines the performance in the previous financial year and current operations. ${ }^{540}$ As each financial review is reached the question is proposed that the select committee report be noted. ${ }^{541}$ The debate goes for up to three hours. The responsible Minister may make multiple five minute speeches but not normally more than two consecutive speeches. Other members may make two five minute speeches for each financial review. ${ }^{542}$

\section{Other Parliamentary Scrutiny}

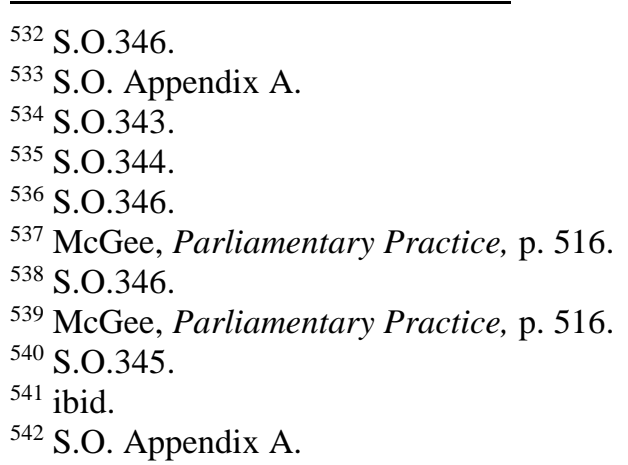


Parliament's control and security of government expenditure is not limited to the supply and financial review processes. Several interviewees stressed that the government is held accountable through parliamentary questions, both oral at question time and through written questions, put to the responsible Minister. ${ }^{543}$ Questions are asked by members that cover government expenditure both directly and indirectly. Requests for information under the Official Information Act 1982 are also used to hold the government to account for government expenditure. ${ }^{544}$ General, urgent and special debates may also provide opportunities. ${ }^{545}$ Furthermore, select committees can receive briefings on and undertake inquiries at their own initiative into matters relating to their subject area including government expenditure. ${ }^{546}$ As such there are many ways and opportunities for members to control and scrutinise government expenditure outside of the formal supply and financial review processes.

\footnotetext{
${ }^{543}$ S.O.375-385.

${ }^{544}$ New Zealand Parliament, 'Official Information Act 1982', 27 August 2013, http://www.legislation.govt.nz/act/public/1982/0156/latest/DLM64785.html (28 September 2013), s.12. ${ }^{545}$ McGee, Parliamentary Practice, p. 509; S.O.386-389.

546 S.O.186.
} 
Table 3.1: House Debate Time Limits and MPs Speaking Times ${ }^{547}$

\begin{tabular}{|c|c|c|c|}
\hline Debate Type & $\begin{array}{c}\text { Total } \\
\text { debate } \\
\text { time } \\
\text { (hours) }\end{array}$ & $\begin{array}{l}\text { Ministers or particular members } \\
\text { speaking time (minutes) }\end{array}$ & $\begin{array}{c}\text { Other } \\
\text { members } \\
\text { speaking time } \\
\text { (minutes) }\end{array}$ \\
\hline Imprest Supply Bill & 3 & N/A (Not Applicable) & 10 \\
\hline $\begin{array}{c}\text { Budget Policy } \\
\text { Statement Debate }^{548}\end{array}$ & 2 & N/A & 10 \\
\hline Budget Debate & 14 & $\begin{array}{l}\text { Minister of Finance delivering } \\
\text { Budget statement has unlimited } \\
\text { time. Leaders of parties with six or } \\
\text { more members speak for } 20 \text { minutes } \\
\text { each. Minister in reply } 10 \text { minutes. }\end{array}$ & 10 \\
\hline Estimates Debate & 8 & $\begin{array}{l}\text { Minister in charge of the Vote may } \\
\text { make multiple } 5 \text { minute speeches } \\
\text { but not normally more than two } \\
\text { consecutive speeches. }\end{array}$ & $\begin{array}{l}\text { Not more than } \\
\text { two speeches of } \\
5 \text { minutes each } \\
\text { for each Vote. }\end{array}$ \\
\hline $\begin{array}{l}\text { Debate on the third } \\
\text { reading of main } \\
\text { Appropriation Bill } \\
\text { A49 }\end{array}$ & 3 & N/A & 10 \\
\hline $\begin{array}{c}\text { Supplementary } \\
\text { Estimates debate }^{550}\end{array}$ & 3 & N/A & 10 \\
\hline $\begin{array}{c}\text { Financial Review } \\
\text { Debate }\end{array}$ & 4 & $\begin{array}{l}\text { Minister in charge of the annual } \\
\text { financial statements of the } \\
\text { government or Minister responsible } \\
\text { for a department or office of } \\
\text { Parliament may make multiple } 5 \\
\text { minute speeches but not normally } \\
\text { more than two consecutive speeches. }\end{array}$ & $\begin{array}{l}\text { Not more than } \\
\text { two speeches of } \\
5 \text { minutes each } \\
\text { for each review. }\end{array}$ \\
\hline $\begin{array}{l}\text { Debate on financial } \\
\text { reviews of Crown } \\
\text { entities, SOEs and } \\
\text { public organisations }\end{array}$ & 3 & $\begin{array}{l}\text { Responsible Minister for the Crown } \\
\text { entity, public organisation or SOE } \\
\text { may make multiple } 5 \text { minute } \\
\text { speeches but not normally more than } \\
\text { two consecutive speeches. }\end{array}$ & $\begin{array}{l}\text { Not more than } \\
\text { two speeches of } \\
5 \text { minutes each } \\
\text { for each review. }\end{array}$ \\
\hline
\end{tabular}

\footnotetext{
${ }^{547}$ All debate time limits and speaking times taken from S.O. Appendix A.

54812 speeches of 10 minutes.

${ }^{549}$ Including when combined with debate on an Imprest Supply Bill.

550 ibid.
} 


\section{Controller and Auditor-General}

The Auditor-General has a central role in the parliamentary control and scrutiny of government expenditure. As watchdog the Auditor-General 'acts as a check and balance on how public money is being collected and spent' providing Parliament with independent assurance that "public sector organisations are operating and accounting for their performance in the way Parliament intended'. ${ }^{551}$ The Auditor-General performs the audit and controller functions. ${ }^{552}$ The controller function involves checking that public money is spent only as approved by Parliament. ${ }^{553}$ The audit function involves auditing all public entities, undertaking performance audits and inquiries, and providing additional auditing or assurance services. ${ }^{554}$ The Auditor-General is an officer of Parliament appointed by the GovernorGeneral on the recommendation of the House. ${ }^{555}$ The Officers of Parliament Committee recommends a person to serve as the Auditor-General. ${ }^{556}$ The Auditor-General is appointed for a single term of up to seven years. ${ }^{557}$ The Governor-General may suspend or remove the Auditor-General from office. ${ }^{558}$ The deputy Auditor-General is appointed the same way serving for up to five years and may be reappointed. ${ }^{559}$ The deputy with restrictions may carry out all the functions, duties and utilise all the powers of the Auditor-General. ${ }^{560}$ The Auditor-General is divided into two separate units the Office of the Auditor-General and Audit New Zealand. The Office is responsible for planning, reporting to the House, undertaking performance audits and inquiries, appointing and monitoring auditors, setting auditing standards and reviewing work undertaken on the Auditor-General's behalf. Audit New Zealand undertakes auditing work on the Auditor-General's behalf along with private sector auditors. ${ }^{561}$ Together they are known as 'appointed auditors'. 562

The Auditor-General is independent and has extensive powers. The Auditor-General and those working on the Auditor-General's behalf must act independently. ${ }^{563}$ The Auditor-

\footnotetext{
${ }^{551}$ Controller and Auditor-General, 'All about the Controller and Auditor-General', February 2012, http://www.oag.govt.nz/about-us/frequently-asked-questions/controller-and-auditor-general.pdf (26 July 2012), p. 3.

552 ibid, p. 3.

553 ibid, p. 9.

554 ibid, p. 11

555 PAA, s.7.

556 S.O.392.

557 PAA, Schedule 3.

558 ibid.

${ }^{559}$ PAA, s. 11 and Schedule 3.

${ }^{560}$ PAA, s. 12.

561 Auditor-General, 'All about the Controller and Auditor-General', p. 5.

${ }^{562}$ McGee, Parliamentary Practice, p. 504.

563 PAA, s.9.
} 
General does not question government policy. ${ }^{564}$ The Auditor-General cannot be an MP or local representative and cannot hold other employment without approval from the Speaker. ${ }^{565}$ The House appoints an independent auditor to audit the Auditor-General. ${ }^{566}$ The AuditorGeneral has extensive powers that enable it to effectively carry out its functions. The office of the Auditor-General has the power to obtain information from any public entity or person necessary to exercise or perform the functions, duties, or powers of the office. ${ }^{567}$ Public entities must ensure that the Auditor-General has access to any required information. ${ }^{568}$ The Auditor-General can require a person to give evidence under oath and inspect bank accounts. ${ }^{569}$ The Auditor-General may report to any Minister, House committee, public entity or person. ${ }^{570}$ Finally, the Auditor-General has the power to disclose information. ${ }^{571}$

\section{Audit Function}

The Auditor-General performs the audit function by undertaking annual audits, performance audits and inquiries. The Auditor-General is the auditor for all public entities and must audit the financial statements, accounts and other information that public entities are required to have audited. ${ }^{572}$ Through the audit function the Auditor-General provides assurance to Parliament that public entities are accurately reporting their activities. ${ }^{573}$ The Auditor-General observes issues relating to performance, waste, probity and financial prudence, authority and accountability. The audit function centres on the undertaking of annual audits that involves gathering all the information and explanations needed to obtain reasonable assurance that financial statements and other information do not have material misstatements caused by fraud or error'. ${ }^{574}$ Audit reports evaluate the presentation and comment on the financial control systems and the 'financial culture' within the entity. ${ }^{575}$ The subsequent audit report, including the audit opinion, forms a part of the entity's annual report. The audit report

\footnotetext{
${ }^{564}$ McGee, Parliamentary Practice, p. 71.

565 PAA, s.8.

${ }^{566}$ McGee, Parliamentary Practice, p. 504; PAA, s.38.

${ }^{567}$ PAA, s. 25.

568 PAA, s.24.

${ }^{569}$ PAA, s.26-s.27.

570 PAA, s. 21.

571 PAA, s.30.

572 PAA, s.14-s. 15.

${ }^{573}$ Auditor-General, 'All about the Controller and Auditor-General', p. 7.

574 ibid, p. 11.

${ }^{575}$ McGee, Parliamentary Practice, p. 505.
} 
contains information to make it easier to read. ${ }^{576} \mathrm{~A}$ further report is provided to the entity and covers issues that were found. ${ }^{577}$

Performance audits and inquiries are undertaken as a part of the audit function. The Auditor-General carries out performance audits into public entities to examine effectiveness and efficiency, compliance with statutory obligations, use of public resources, probity and financial prudence. ${ }^{578}$ The Auditor-General may carry out an inquiry on its own initiate or at the request of others into any matter relating to a public entity's use of public resources. ${ }^{579}$ Performance audits examining effectiveness and efficiency and all inquiries cannot question government policy. ${ }^{580}$ The Auditor-General may provide other auditing services to public entities. ${ }^{581}$ Auditors follow the Auditor-General's auditing standards that incorporate the New Zealand Institute of Chartered Accounts' auditing standards. ${ }^{582}$ The Auditor-General must regularly publish the auditing standards it uses through a report to the House with any significant changes included in its annual report. ${ }^{583}$

\section{Controller Function}

The Auditor-General as controller ensures that public money is spent only as Parliament has approved. All public money must be in a Crown Bank account or a departmental bank account. ${ }^{584}$ Public money may be transferred between Crown Bank Accounts and departmental bank accounts without an appropriation. ${ }^{585}$ However, public money can only be withdrawn from a Crown or a departmental bank account if there is an appropriation or other statutory authority providing for the withdrawal. ${ }^{586}$ The Auditor-General in carrying out the controller function provides Parliament with assurance that expenses and capital expenditure incurred by a department or office of Parliament were for lawful purposes and were within an appropriation or other authority. ${ }^{587}$ The controller function is carried out by checking monthly Treasury reports and through the audit of appropriations. The Treasury is required to provide monthly reports that enable the Auditor-General to determine that expenses and capital

\footnotetext{
${ }^{576}$ Auditor-General, 'All about the Controller and Auditor-General', p. 11.

577 ibid

578 ibid., p. 12; PAA, s. 16.

${ }^{579}$ PAA, s. 18 .

${ }^{580}$ PAA, s. 16 and s. 18 .

${ }^{581}$ PAA, s. 17.

${ }^{582}$ Auditor-General, 'All about the Controller and Auditor-General', p. 11.

${ }^{583}$ PAA, s.23.

584 PFA, s.65U.

${ }^{585}$ PFA, s.65V.

${ }^{586}$ McGee, Parliamentary Practice, p. 455; PFA, s.65V.

${ }^{587}$ Auditor-General, 'All about the Controller and Auditor-General', p. 9.
} 
expenditure were incurred within an appropriation or other authority from Parliament. ${ }^{58}$ The Auditor-General may use its powers to verify the report. ${ }^{589}$ The Treasury reports are generally limited by only providing information on breaches of appropriation by amount. ${ }^{590}$ The primary way that the controller function is performed is through the audit of appropriations or other authorities. ${ }^{591}$ Appropriations are audited as a part of annual audits and it is where most issues are identified. ${ }^{592}$ The controller function is supported by the Auditor-General's ability to direct a Minister to report to the House and stop payments from a Crown or a departmental bank account. ${ }^{593}$

\section{Relationship with the House}

The Auditor-General reports to and has a close relationship with the House especially its select committees. The Auditor-General presents a draft annual plan to the House through the Speaker that describes its proposed work program for the coming year. Both the Speaker and the FEC consider and respond to the draft. ${ }^{594}$ The Auditor-General alters the plan considering the comments made and indicates any requested changes that were not included. The final annual plan is submitted to the House before the start of the financial year. ${ }^{595}$ The AuditorGeneral produces an annual report for the House like that required of departments, including discussion on the implementation of the annual plan. ${ }^{596}$ The Auditor-General reports to the House at least once a year on matters arising out of its performance and exercise of its functions, duties and powers. ${ }^{597}$ All reports from the Auditor-General are referred to the FEC which may consider the report itself, or where appropriate refer it to another committee. ${ }^{598} \mathrm{~A}$ code of practice serves as a guide to the nature and extent of assistance provided by the Auditor-General to the House, select committees and individual MPs. ${ }^{599}$ The Auditor-General may assist select committees with their examination of the Estimates and financial reviews, consideration of bills, inquiries, and consideration of reports from the Auditor-General, as

\footnotetext{
${ }^{588}$ PFA, s.65Y; Auditor-General, 'All about the Controller and Auditor-General', p. 9.

${ }^{589}$ PFA, s.65Y.

${ }^{590}$ Auditor-General, 'Central Government', p. 56.

${ }^{591}$ PAA, s.15; McGee, Parliamentary Practice, p. 455.

592 Auditor-General, Central Government, p. 54.

${ }^{593}$ PFA, s.65Z and s.65ZA.

${ }^{594}$ McGee, Parliamentary Practice, p. 75.

595 PAA, s.36.

596 PAA, s.37.

${ }^{597}$ PAA, s. 20.

598 S.O.393.

${ }^{599}$ Officers of Parliament Committee, 'Code of Practice for the Provision of Assistance by the Auditor-General to the House, Select Committees and Members of Parliament', I.15C, August 2007, http://www.parliament.nz/resource/0000026015 (14 December 2012).
} 
well as address requests or inquiries made straight to the Auditor-General by individual MPs. ${ }^{600}$ The Auditor-General and the FEC consult each year on the nature and extent of the assistance that will be provided. ${ }^{601}$

\section{Finance and Expenditure Committee}

The FEC plays an important role in controlling and scrutinising government expenditure. There are 12 subject select committees created by the House. All select committees must consider bills, petitions, treaties and other matters referred to it. Select committees may also undertake, on their own initiative, inquiries into matters relating to their subject area and they can receive briefings on proposed inquiries. ${ }^{602}$ The FEC is specifically tasked with auditing the financial statements of the government and government departments, and for the subject areas of government finance, revenue and taxation. ${ }^{603}$ The government is not required to respond to the House on recommendations made in a report on the Estimates, Supplementary Estimates and financial reviews but is required to do so for inquiries. ${ }^{604}$ Select committees are able to create subcommittees to help undertake their work. ${ }^{605}$ The Business Committee determines the size of each committee with overall membership closely proportional to parties' membership in the House. The FEC like all select committees does not have a set size, although it is one of Parliament's largest. ${ }^{606}$ The FEC currently has 11 members representing four parties, but has had 12 members representing six parties in the recent past. ${ }^{607}$ The committee's large size allows for all parties to have a member on the committee if they wish while maintaining proportionality. The FEC has a government chairperson and majority, as has been historical practice, although neither is required. Not all select committees have government chairpersons and majorities.

The FEC holds a premier or king status among Parliament's select committees due to its co-ordinating role and the body of work it undertakes. The FEC's high status does not come solely from its subject area. Although the committee is 'pre-eminent' in undertaking financial work, all select committees play an important part in examining government expenditure. ${ }^{608}$ The importance of the FEC comes from its leadership position. The FEC is

\footnotetext{
600 ibid, p. 5.

601 ibid, pp. 7-8.

602 S.O. 186.

603 S.O. 185.

604 S.O.248.

${ }^{605}$ S.O. 185 .

${ }^{606}$ S.O.182.

${ }^{607}$ McGee, Parliamentary Practice, p. 451.

${ }^{608}$ ibid.
} 
the 'linchpin' for the select committee examinations of the Estimates, Supplementary Estimates, reports on non-departmental appropriations and the undertaking of financial reviews through its allocation duty. ${ }^{609}$ The FEC performs a leadership role in how select committees perform those examinations. The leadership role is reflected in the issuing of the standard estimates questionnaire and its consideration of proposed changes to how both financial and non-financial information is presented. ${ }^{610}$ The FEC examines financial management legislation, such as amendments to the PFA, and has the 'heavy burden' of considering most tax legislation. ${ }^{611}$ The FEC is tasked with considering and reporting on the aforementioned fiscal responsibility documents. ${ }^{612}$ Furthermore, the FEC examines monetary policy by holding public hearings for the quarterly monetary policy statements and the six monthly financial stability reports from the Reserve Bank with the bank's Governor. ${ }^{613}$

\section{Conclusion}

Parliament theoretically has extensive practice and procedures for controlling and scrutinising government expenditure. Parliament is able to perform the function because the government needs parliamentary consent to spend public money. At the centre of Parliament's procedure and practice is the supply process, where Parliament is able to provide its consent, and the financial review process, where government expenditure is checked after it has occurred. The two processes revolve around the FEC-led select committee examinations and the House's various debates. The Auditor-General has a key role with its audit and control functions that provide Parliament with assurance that the government has been honest with its expenditure of public money. The appropriations and accounting systems provide for parliamentary control and facilitate scrutiny of government expenditure. The practice and procedures enable Parliament to perform the function. The next chapter evaluates Parliament's control and scrutiny of government expenditure to determine whether the practice and procedures are effective.

\footnotetext{
609 ibid.

610 ibid, p. 452.

611 ibid.

612 S.O.330, 331 and 340.

${ }^{613}$ McGee, Parliamentary Practice, p. 452.
} 


\section{Chapter Four: Evaluation}

\section{Introduction}

The following chapter examines Parliament's effectiveness at controlling and scrutinising government expenditure. It critiques the procedure and practice described in the previous chapter to determine its appropriateness for aiding Parliament in the undertaking of the function. MPs, naturally, are at the centre of Parliament's undertaking of the function. As stated by Pallot 'ultimately, the effectiveness of parliamentary control depends on the vigour of Parliament's scrutiny and debate'. ${ }^{614}$ Therefore, emphasis is placed throughout the chapter on examining the behaviour of MPs and how the various elements are, or can be, utilised to assist them in performing the role. Crucially the core evidence comes from MPs themselves, who are in an ideal position to pass judgement. This chapter broadly follows the same structure as the previous one. The first section has current MPs describe what they believe is Parliament's role and their overall opinion of its performance. The central provisions and the impact of MMP are also considered in that section. The appropriations system, Budget documentation, and the financial statements and accounting system that facilitate Parliament's performing of the function are then critiqued. The parliamentary process section discusses the debates and select committee examinations where MPs exert Parliament's right to scrutinise government expenditure. The Auditor-General, a key agent in assisting Parliament to perform the function, is subsequently considered with the focus on the audit and control functions as well as the relationship with the House. Finally, the Finance and Expenditure Committee (FEC) is examined in depth using specified success factors.

\section{General Themes and Central Provisions}

\section{Role of Parliament}

MPs were asked to describe the appropriate role for Parliament in relation to government expenditure. It was unanimously recognised that controlling and scrutinising government expenditure is an important role for Parliament. The history of the role was recognised with one member stating that:

${ }^{614}$ Pallot, 'Accounting, Auditing and Accountability', p. 72. 
The fundamental principle goes back to the English revolution that governments should not be able to spend money without the authority of Parliament and that is a very sound principle that continues to be implemented in New Zealand. ${ }^{615}$

Members stated that Parliament's role is to approve, oversee and review government expenditure. One member summarised that Parliament's role is:

To scrutinise, to keep check on, and to challenge the validity and the value of the spending and to make sure that spending is transparent. Spending not only from an auditing perspective but also in terms of the efficacy and the extent to which it advances the government's policy aims. ${ }^{616}$

Interviewees stressed that the role is performed on behalf of taxpayers with one member stating that:

The taxation of citizens is effectively a long term social as well as legal contract. Government cannot spend money and tax people forcibly without the authority of Parliament. Parliament provides checks and balances upon that process on behalf of the people. ${ }^{617}$

Parliament's role of controlling and scrutinising government expenditure was connected to that of informing the public of the government's actions. Scrutiny of government expenditure is not limited to the executive. It extends to the whole public sector with Parliament aiming to impose incentives and create a culture whereby public money is spent as though it were their own. Regular scrutiny was seen as an important discipline that ensures the government is operating effectively and efficiently.

There were two key limitations identified on Parliament's role of controlling and scrutinising government expenditure. The first limitation is that the function is only one of Parliament's roles. Parliament has other roles (including law making, representation and providing for a government) that are of equal or greater importance. The second limitation is that Parliament's role is only to control and scrutinise government expenditure. MPs outside of the executive have little or no role in determining government expenditure. The executive is responsible for instigating government expenditure through the supply process with backbench government MPs having a limited influence through Caucus and Caucus committees. The Treasury was identified as undertaking important control and scrutiny work. The first level of scrutiny by elected representatives and the most significant initial scrutiny of government expenditure is performed by Cabinet. Parliament was identified as having an important role in forming the legal framework in which government expenditure occurs, principally the Public Finance Act 1989 (PFA).

\footnotetext{
${ }^{615}$ Interview with anonymous MP, 6 November 2012.

${ }^{616}$ Interview with anonymous MP, 23 January 2013.

${ }^{617}$ Interview with anonymous MP, 15 November 2012.
} 


\section{The effectiveness of Parliament}

Opinion was divided amongst MPs as to how effectively Parliament performs the function. The majority argued that Parliament is fairly good at controlling and scrutinising government expenditure. Parliament was given a $\mathrm{B}+$ grade with its processes and systems frequently described as 'robust'. ${ }^{618}$ Parliament's effectiveness was linked by several interviewees to the Auditor-General and the select committee process. Parliament's control of government expenditure was seen as exceptional by one MP with good practices and procedures for tracking public money and ensuring it was not spent inappropriately. The problem is with the quality of the scrutiny with concerns raised about how effective Parliament is at questioning:

Whether we are getting the best bang for the buck, not just whether it was being used appropriately, but if it was being used as well as it could be, and whether it was really delivering on our public policy outcomes. ${ }^{619}$

Scrutiny instead is 'superficial' and at a 'fairly high level' with the focus inevitably on current political issues rather than government expenditure. ${ }^{620}$ There is significant control and scrutiny at the governmental or ministerial level but not at the lower operational or departmental level. There was a firm impression that a great deal of public money goes into departments 'that are still quite opaque' to Ministers and MPs. ${ }^{621}$ Interviewees were reluctant to say that the public sector has a culture of wastefulness.

Parliament's undertaking of the function was criticised with the recurring theme being the ability and willingness of MPs to perform the role. There was widespread criticism of Parliament's performance. The argument was made that government expenditure is simply 'rubber stamped'. ${ }^{622}$ Parliament was viewed as having a 'big machine' to examine government expenditure that does not achieve what it aims to do. ${ }^{623}$ However, the member believes that the mechanisms available can and do work, but that requires MPs to have 'their heads around the issues and understanding what is going on... making sure that the collective does not make a mistake'. ${ }^{624}$ That argument is supported by a further member who stated that 'you can set up the structure as neat and tidy as you wish but you can't control the calibre of questions that members will ask during the Estimates and financial review processes'.625 Furthermore, MPs were seen to rarely examine government expenditure in detail. Rather than

\footnotetext{
618 Anonymous MP, 6 November 2012.

${ }^{619}$ Anonymous MP, 23 January 2013.

${ }^{620}$ Interview with anonymous MP, 23 October 2012.

${ }^{621}$ Anonymous MP, 23 January 2013.

${ }^{622}$ Interview with anonymous MP, 2 November 2012.

623 ibid.

${ }^{624}$ Anonymous MP, 23 October 2012.

${ }^{625}$ Anonymous MP, 6 November 2012.
} 
asking the hard questions they attempt to score political points. A major source of the problem is the large amount of reading required to prepare for debates and select committee meetings on top of the other work MPs are expected to perform. Several interviewees stressed that MPs must balance their commitments to Parliament as well as their constituency, party and family. The level of talent possessed by MPs was not often perceived as sufficient for effective scrutiny particularly with the lack of necessary training. With MPs coming from diverse backgrounds it is case of how to effectively utilise their expertise.

Reforms to legislation and parliamentary procedure in the past 25 years were seen to have improved Parliament's ability to control and scrutinise government expenditure. The PFA received high praise as it laid the solid ground rules and basis for the operation of the current system. The usage of accrual accounting and appropriations based on inputs, outputs and outcomes was commended. The majority of interviewees praised the Fiscal Responsibility Act 1994 (FRA) believing that it has improved their ability to hold the government to account. The principles of responsible fiscal management and the related documents were perceived as critical to Parliament's performing of the function. Members recognised that prior to the FRA it was difficult for the opposition to know the true state of the government's finances. The impact of both the PFA and FRA was summarised by one member that stated the government must now:

Lift its skirt... The government can't fudge it, it's open for all to see and everyone can make their own assessment, the information is there. I think they've been critical to making government know that they will be absolutely accountable for the state of the books at all times... and be required to explain why they are where they are. ${ }^{626}$

The change to separate supply and financial review processes was acknowledged as a significant improvement. Members like the separate processes because it ensures that past and future government expenditure are examined separately.

\section{Confidence and Supply}

The question of what should happen if the government were to fail to obtain supply from Parliament received a consistent response. It was stressed that the government must maintain the confidence of the House including supply. As set out by one member 'it's a big leaver, it acts as a very strong discipline'. ${ }^{627}$ However, a government failing to retain supply is unlikely even under MMP because it would reflect badly on those who withdrew support. The

\footnotetext{
${ }^{626}$ Anonymous MP, 23 January 2013.

${ }^{627}$ Anonymous MP, 6 November 2012.
} 
consensus was that if supply was not provided an attempt should be made to form a new government from the existing Parliament. If that were to fail a new election must be held. The majority of MPs believe that a fresh election would be the likely outcome if Parliament refused to grant supply. There was contention about providing imprest supply or other contingency provision to fund government in the interim. Most members believed that should occur if required. MPs would not want to be associated with a government shutdown, they would not play games. The grant of imprest supply must be well crafted to ensure the principle that the government cannot continue in office without confidence and supply is not diluted. It was acknowledged that the power lies with the Governor-General. As such there is historical precedent that the Governor-General can check with the Prime Minister that the government has sufficient supply to function before dissolving Parliament. ${ }^{628}$

\section{$M M P$}

The shift to the MMP electoral system has not transformed Parliament's performing of the function. When asked about the effect of MMP members' responses varied from it having a negligible positive to a slightly negative impact. The main improvement is related to having a more representative Parliament with debate that better reflects public opinion. MMP has also improved select committee examinations. They are now 'more vibrant and meaningful...there is more real engagement, interest and transparency'. ${ }^{629}$ MMP has removed the government's complete dominance of the select committee system because they do not necessarily hold all the chairpersonships and majorities. ${ }^{630}$ However, MPs carry out their roles the same way as under FPP. Their attitude towards examining government expenditure has not shifted. Although the number of questions asked by members through written questions and the Official Information Act requests has surged as a result of the introduction of minor parties. ${ }^{631}$ The conclusion of Boston and Church that 'the role and influence of Parliament during the legislative phase has altered little under MMP' still stands. ${ }^{632}$ They argue that the House has not become a place for negotiating the details of government expenditure, there is little risk of the government failing to obtain supply, Budgets have not

\footnotetext{
${ }^{628}$ McGee, Parliamentary Practice, p. 446.

${ }^{629}$ Anonymous MP, 23 January 2013.

${ }^{630}$ Richard Norman, Obedient Servants? Management Freedoms \& Accountability in the New Zealand Public Sector (Wellington: Victoria University of Wellington Press, 2003), p. 156.

631 ibid, p. 160.

${ }^{632}$ Boston and Church, 'The Budget Process in New Zealand', p. 43.
} 
received any significant amendment following its presentation, and governments have rarely had to resort to the financial veto. ${ }^{633}$

\section{Financial Veto}

The financial veto ensures that the executive is definitely responsible for government expenditure and does not compromise parliamentary control and scrutiny. There was near complete support for MPs to have the ability to propose amendments and new government expenditure balanced by the executive having access to the financial veto. The ability to propose and amend government expenditure is a valued way to scrutinise the government. The veto was viewed favourably compared to the previous rules. The veto was recognised as a necessary mechanism to ensure that the system works whereby the executive is responsible for government expenditure and Parliament for critiquing it. The argument was that the executive must be able to govern and should only be held accountable for government expenditure that it is willing to take responsibility for. However, the veto must be treated as a 'reserve power, its use needs to be rare and sparing'. ${ }^{634}$ Members believe that generally the veto is only used for expenditure proposals which would have had more than minor impact. The argument that the veto is undemocratic was dismissed because governments risk political punishment if they abuse it. Any abuse will result in ridicule from the media and the opposition. They must still maintain the confidence of the House and face the next general election. As argued by McGee the ability to amend expenditure is not 'fundamental' but the ability to scrutinise the executive's proposals is. ${ }^{635}$

\section{Appropriations}

There were few concerns about the appropriations systems with the various type and forms seen as necessary. Pallot provides that a fundamental issue with appropriations is the:

trade-off between flexibility and parliamentary control... Narrower, more specific appropriations permit a more stringent level of parliamentary control and may be sought in areas of high political (not just financial) risk, but too many appropriations become unmanageable. ${ }^{636}$

A senior member believes that the appropriations system is suitably balanced at present. Newberry and Pallot argue that MPs do not fully understand appropriations. Part of the problem is that the PFA does not contain a definition for 'appropriation' despite the immense

\footnotetext{
633 ibid.

${ }^{634}$ Interview with anonymous MP, 31 November 2012.

${ }^{635}$ McGee, The Budget Process, p. 130.

${ }^{636}$ Pallot commentary to Dale, 'The Budget Process', p. 250.
} 
importance of the term. MPs were seen to have difficulty recognising that appropriations are accrual-based. Particularly that they do not necessarily provide the amount stated in cash for the activity being financed. ${ }^{637}$ Occasionally there are issues with appropriations according to the senior member but the system ensured that any abuse was stamped out. The challenge for Parliament is to expose any abuse. There must be 'compelling justification' for permanent appropriations according to McGee. ${ }^{638}$ There is little to suggest that permanent appropriations are abused. The importance of closely watching permanent legislative authorities was stressed due to past abuse. Historically the problem was not incompetence but deliberate efforts to hide information and prevent the exposure of nasty surprises.

The various appropriation types do not have an adverse impact on parliamentary control. Permanent legislative authorities, emergency expenditure provisions and multi-year appropriations were of little concern to interviewees. Multi-year appropriations were described as a necessary flexibility for governments with the Budget process getting better at handling them. It was pointed out that all multi-year appropriations must go through the supply process each year because, although they provide an expectation of future funding, Parliament will not necessarily continue to approve it. The emergency expenditure provisions were perceived as appropriate because the government must have the ability to react following a disaster or emergency. The freedom to spend funds is balanced out by the requirement that they later go through the House as appropriations. Imprest supply is typically used following a disaster although the emergency expenditure provisions were used following the 2011 Canterbury earthquake. ${ }^{639}$ There was concern from Newberry and Pallot that the introduction of multi-class appropriations would reduce parliamentary control. The trade off with managerial flexibility was not seen as a fair balance. They were also concerned that having multiple Ministers responsible for a Vote would reduce responsibility and accountability. ${ }^{640}$ Multi-class appropriations and in some cases having more than one responsible Minister are both deviations from the appropriations concept although neither is detrimental to parliamentary control.

\section{Budget and Estimates Documentation}

The Estimates documentation provided to Parliament was a major area of contention. Most members had issues with the Estimates relating to their form and content and the ability or

\footnotetext{
${ }^{637}$ Newberry and Pallot, 'A Wolf in Sheep's Clothing?', p. 271.

${ }^{638}$ McGee, The Budget Process, p. 130.

${ }^{639}$ Treasury, 'Putting it Together', p. 34.

${ }^{640}$ Newberry and Pallot, 'A Wolf in Sheep's Clothing?', p. 271.
} 
desire of MPs to comprehend the information they contain. Opinion was split on how comprehensible the Estimates are. The Estimates were generally seen to contain an abundance of information but were difficult to understand. Drilling down into a Vote can be a complex and time consuming task. Opposition members in particular believed that real effort is required to dissect the Estimates in the limited time available, although it is easier with experience. One opposition MP surmised that:

Those kinds of things which are hidden in there, the inconsistencies in the budget, what mistakes have been made and the way in which cuts are intended to be made are not always transparent in the initial document. Even where they are, trying to compare them in an incredibly short time frame is not possible. ${ }^{641}$

Accountability is not lacking because information is hidden according to one member. Budget documentation is full of information, transparent and easy to access. The member argued that MPs who are trying to work through it know where to look and what to find. The documentation may not be that effective for the public at large but he was unsure how many actually read the documents. Several members expressed that the open availability of Budget documentation is important because it allows the public to bring forward issues and the media if they get a 'whiff' of a potential story. ${ }^{642}$

There were issues with the information contained in the Estimates documentation. A major issue with the Estimates is striking the right balance between the level of detail and the ability of the reader to comprehend their contents. As stated by one member:

I don't think there's any such thing as perfection in this regard. The less detail you have, and the more general it is, the harder it is to hold people to account for meaningful amounts of money rather than the overall amount. On the other hand, the more details you get into the harder they are to follow and therefore it's hard for people to use them except if they are really expert in these matters. ${ }^{643}$

The current balance was seen as appropriate. Interviewees had two main issues with Estimates documentation. First, requiring MPs to plug together the various documents and those from previous years was seen as unreasonable. Secondly, there is an overemphasis on accountancy in the Estimates documentation, although it was acknowledged as necessary. Members want more information on what government expenditure is expected to deliver. As stipulated by one MP 'the focus is too much on black letter accounting; how big the numbers are, rather than what outcome the money is achieving, ${ }^{644}$ Expenditure is not adequately tied

\footnotetext{
${ }^{641}$ Interview with anonymous MP, 8 November 2012.

${ }^{642}$ Anonymous MP, 15 November 2012.

643 ibid.

${ }^{644}$ Anonymous MP, 23 January 2013.
} 
to 'measurable' outcomes according to another member, that 'help to very quickly identify where money is being squandered' ${ }^{645}$ Norman identifies that governments are reluctant to specify their desired outcomes too explicitly. ${ }^{646}$ Outcome descriptions are frequently 'vague' with a lack of information on how progress will be measured. ${ }^{647}$ Progress has been made with stating and reporting against outcomes according to one interviewee. However, resistance to stating outcomes will continue due to the number of factors, many uncontrollable, which influence them.

MP's dedication to reading the documentation was the issue, not the content or format of the Estimates according to several interviewees. One member stressed that the real issue is the commitment of MPs to reading the documentation. The member believes that much of the detail in the Estimates and other documents 'never sees the light of day and there is a wealth of material in terms of government programs, intentions and what changes are being made'. ${ }^{648}$ Frustration was expressed at how the extensive documentation was 'pushed aside' by MPs surmising that 'the form and content is fine, just the use to which they are put is questionable'. ${ }^{649}$ Another MP was of a similar opinion stating that the 'Estimates certainly assist Parliament in that they provide a bunch of information, but it all just gets rubber stamped' ${ }^{650}$ It is important that there is expertise available to 'unscramble' the information contained across the various documents. ${ }^{651}$ Content and format changes frustrate MPs. Several interviewees stated the work of the Auditor-General in interpreting and briefing select committees on the Estimates helps immensely.

\section{Standard Estimates Questionnaire}

The standard estimates questionnaire was controversial. Opposition MPs view the questionnaire as a valuable tool for getting detailed information on the public record that would otherwise not be available. The questionnaire was seen by them as well-crafted and serving as a solid starting point for the select committee examinations. Opposition members were frustrated with departments providing 'pro-forma' answers. ${ }^{652}$ Departments were seen to go to great effort to avoid answering questions and hide information. The questionnaire

\footnotetext{
645 Anonymous MP, 23 October 2012.

${ }^{646}$ Norman, Obedient Servants, p. 105.

647 ibid.

${ }^{648}$ Anonymous MP, 31 November 2012.

649 ibid.

${ }^{650}$ Anonymous MP, 2 November 2012.

${ }^{651}$ Interview with anonymous MP, 30 January 2013.

${ }^{652}$ Anonymous MP, 2 November 2012.
} 
was only seen to work if the opposition could get the answers they need, while recognising they may not get the answers they want. Inadequate responses were put down to insufficient resources in departments and pressure from Ministers to restrict the flow of information. Government MPs restrict the questionnaires because of the cost to departments and the ammunition answers could provide to the opposition. It was acknowledged that providing answers was a 'nuisance' for departments. ${ }^{653}$ Schick comments that the substantial information requests made in the questionnaire is due to the Estimates lacking data valued by MPs. ${ }^{654}$ However, it was acknowledged by an opposition member that the questionnaires rarely produce useful information and they do not make much use of the material.

There was considerable criticism of the standard estimates questionnaire from government MPs. They were seen to waste departments' time and as a result public money. They questionnaire is overly long considering it asks predominately about trivial matters and for overly complex data. There was the impression that the information obtained was never actually used and the member could not trace an opposition attack back to a questionnaire. The member did concede that specific questions could provide useful information. The opposition has the absolute right to ask questions through the questionnaire with the member stating that 'a part of the price we pay for our free democracy is that there can be a lot of fishing exercises'. ${ }^{655}$ A further government member described the questionnaire as flagging and repetitive.

\section{Fiscal Responsibility Documents}

The fiscal responsibility documents were praised. Economic and fiscal updates are particularly important for transparency. The pre-election update was highly valued by MPs being described as 'exceedingly useful and important'. ${ }^{656}$ The update enables politicians to hold each other to account for the policy promises they make during the campaign. There was criticism of the pre-election update with one member arguing that the document is weakened by the government not being required to provide new information that arises between the documents' presentation and Election Day. The budget policy statement was described as too 'pre-functionary' with the document and the FEC hearing having devolved into the reiteration

\footnotetext{
${ }^{653}$ Anonymous MP, 15 November 2012.

${ }^{654}$ Allen Schick, 'The Spirit of Reform: Managing the New Zealand State Sector in a Time of Change', June 1996, http://www.ssc.govt.nz/sites/all/files/spirit_of_reform_all.pdf (27 July 2012), pp. 77-78.

655 Anonymous MP, 23 January 2013.

${ }^{656}$ Interview with anonymous MP, 28 November 2012.
} 
of wish lists. ${ }^{657}$ There was strong pessimism from one member about the fiscal responsibility documents. The member asserted that they are only as effective as the interest and understanding that MPs and the wider public had in their contents, which was minimal. McGee claims that pre-Budget hearings like those for the budget policy statement should serve as an opportunity to 'channel legislative and public opinion on the Budget into the government's consideration of Budget preparation' ${ }^{658}$ Currently that is not the case with few submissions made on the budget policy statement. ${ }^{659}$

\section{Financial Statements and Accounting}

The accounting system was applauded by most members. The majority of interviewees expressed great confidence in the government's accounting system. The legislative framework, principally the Financial Reporting Act 1993, was viewed as a vital piece of legislation that ensures the government's accounts are prepared in accordance with proper accounting standards and ensure transparency. There was confidence that the government's accounting system is of a high standard when compared internationally. The usage of generally accepted accounting practice (GAAP) and accrual accounting were acknowledged as important and was broadly accepted by most interviewees. GAAP was described as a 'very important discipline' that 'puts a proper constraint on politicians'. ${ }^{660}$ The move from cash to accrual accounting was appreciated as a significant improvement. Norman claims that accrual accounting has made it much easier for MPs to understand the financial statements because it is the 'same accounting language' as that used by the private sector. ${ }^{661}$ Accrual accounting was recognised as providing Parliament with an accurate picture and information on the financial position of departments and the government as a whole. Pallot asserts that accrual accounting ensures 'it is no longer possible to hide the cost of decisions' ${ }^{662}$ There was some disagreement from members on the extent that governments are able to hide financial information. There were concerns from members that the accounting system is becoming too complex and expensive without actually adding much extra value for society.

\footnotetext{
${ }^{657}$ Anonymous MP, 31 November 2012.

${ }^{658}$ McGee, The Budget Process, p. 130.

${ }^{659}$ For example see: The Finance and Expenditure Committee, 'Budget Policy Statement 2013 and Treasury’s Half-year economic and fiscal update', I.3H, December 2012, http://www.parliament.nz/resource/0001871540 (3 November 2013), p. 13.

${ }^{660}$ Anonymous MP, 6 November 2012.

${ }^{661}$ Norman, Obedient Servants, p. 196.

${ }^{662}$ Pallot, 'New Public Management Reform', p. 233.
} 
There was significant criticism of financial statements and the accounting system. The argument was made that there is a lot of subjectivity and variance with how figures and information are presented in the financial statements. The member believes that the presentation of financial information should be 'black and white' but feared that was a 'pipe dream'. ${ }^{663}$ There should be better standardisation of the categories used by departments with the accounting of consultancy spending and policy advice from the department provided as an example. Furthermore, the member was irritated by changes that made comparing financial statements over time difficult. The argument was made that one should take a step back and determine what an accounting system should actually deliver. The member set out that with an accounting system and financial statements:

You want to show with integrity: that's what you collected, that's what you spent and those are the outcomes you've secured, and that's the money that got pocketed, and that money got wasted. ${ }^{664}$

It was stipulated that using those criteria the system and statements are too complicated and fail to deliver the valuable or transparent information required. The financial statements have become too complex for most MPs and the public to comprehend. The member alleged that even highly competent MPs, including qualified accountants, can struggle to understand the financial statements. Newberry and Pallot are scathing of financial statements, especially the annual financial statements of the government, arguing that they are not prepared for the people of New Zealand who should be the intended users. ${ }^{665}$

\section{Parliamentary Process}

\section{Annual Process}

There was strong support for the continued use of an annual cycle by Parliament to control and scrutinise government expenditure. As stipulated by McGee an annual process has 'natural appropriateness'. ${ }^{666}$ Although the government was identified as operating on a three year rolling cycle but it is important that scrutiny is performed annually according to the member. There was concern from interviewees that having an annual process results in an overly short term focus on government expenditure. It was observed that Parliament has improved its critiquing of the long-term impact of government expenditure.

\footnotetext{
663 Anonymous MP, 23 January 2013.

${ }^{664}$ Anonymous MP, 23 October 2012.

${ }^{665}$ Newberry and Pallot, 'A Wolf in Sheep's Clothing?', p. 275.

${ }^{666} \mathrm{McGee}$, The Budget Process, p. 126.
} 


\section{Debate in the House}

Parliament's debate on the Budget, Estimates and financial reviews was heavily criticised. The various debates are of poor quality and resemble general debates even though they are meant to focus on government finance and expenditure. The Budget debate was described as lengthy and formulaic with the initial contributions long set pieces. It was further dismissed as being 'as good a quality as any other debate' with other members rhetorically asking if any quality debate occurs in the House. ${ }^{667}$ The Estimates debate was panned because it is "very rarely a good detailed exchange of ideas on the way money could be spent'. ${ }^{668}$ The Estimates debate was labelled as 'formulaic' and 'high level' with Votes rarely scrutinised in detail. ${ }^{669}$ At best there are 'patches of illumination'. ${ }^{670}$ Debate was characterised as 'theatre' that just 'scratched the sore' with each side doing their utmost to irritate the other. ${ }^{671}$ The debates were defended by a few members with who described them as long and thorough.

Various reasons were provided for the poor quality of debate. The primary reason provided was the adversarial nature of Parliament which results in parties simply reiterating their ideological positions. The debate is subsequently about current political issues rather than government expenditure. MPs' speeches were criticised for their level of repetition. Repetition was blamed on MPs' over reliance on speech notes prepared by research units and that the art of debate has been lost. Simplicity and repetition were recognised as important for politicians when conveying their message to the media and wider public. Making the debates informative and engaging was a challenge according to one member. The public has the tendency to glaze over when government expenditure is discussed in the billions. As a result politicians draw down their debate to make it more tangible to the public. The Budget debate an opposition member claimed was limited by the short time available to examine the large amount of information presented to the House prior to the debate. Time pressure on Parliament and MPs was recognised as a major constraint on their undertaking of the function.

The system used to allocate speaking times and determine what will be debated for the Estimates and financial reviews debate was viewed as appropriate. There was broad satisfaction with the method used to allocate speaking times with proportionality identified as the appropriate guiding principle. There was some divergence in opinion. Opposition

\footnotetext{
${ }^{667}$ Anonymous MP, 6 November 2012.

${ }^{668}$ Anonymous MP, 23 January 2013.

${ }^{669}$ Anonymous MP, 15 November 2012.

${ }^{670}$ Anonymous MP, 28 November 2012.

${ }^{671}$ Anonymous MP, 23 October 2012; Anonymous MP, 6 November 2012.
} 
members stipulated that they would like greater control. A government member was critical of the opposition's power over what was debated. The opposition was seen to pick Estimates and financial reviews based on how politically contentious they were rather then on expenditure or financial performance grounds. The member stipulated that it was fair to an extent as that held Ministers to account in a political scene. However, it resulted in scrutiny equating to 'once over lightly' in true financial accountability terms. ${ }^{672}$

There was consensus that Parliament provides itself with sufficient time to debate government expenditure and to perform the function overall. Newberry and Pallot have slated the decrease in debate time for the Estimates and financial reviews. ${ }^{673}$ The majority of members though, including those in the opposition, argued that the House commits sufficient time to critiquing government expenditure. As put by one member:

In practice a lot of it is taken up with politicking, which is fair enough, but if anybody was of the mind to there are more than enough opportunities to bring things to light and debate them. ${ }^{674}$

A more critical argument was made by another member that since the debates rarely produce anything meaningful there is more than enough time available. While debate time has declined it is not worthwhile extending the current length of the debates as the extra time would not be used effectively. Debates were still considered to have great potential for scrutinising government expenditure but they are currently an ineffective use of the House's time. The length of the debates was viewed as appropriate when balanced against other parliamentary business and the amount of time spent examining government expenditure in select committees provided the process was robust.

Several members stressed that scrutiny of government expenditure was not just through the Estimates and financial review processes. It was argued that the hard hitting financial accountability questions are not asked in select committees but in written questions. The ability of parliamentary questions and Official Information Act requests to assist Parliament in carrying out the function was perceived as dependent on the government's willingness to answer requests and provide information.

\section{Imprest Supply}

The granting of imprest supply by Parliament was not of concern. Parliament's consideration of Imprest Supply Bills was described as a non-event. The question of how seriously the granting of imprest supply was taken by Parliament was raised by one member. MPs were

\footnotetext{
${ }^{672}$ Anonymous MP, 31 November 2012.

${ }^{673}$ Newberry and Pallot, 'Wolf in Sheep's Clothing?', p. 270.

${ }^{674}$ Anonymous MP, 28 November 2012.
} 
identified as not fretting over the granting of imprest supply, viewing it as a necessary formality to 'keep the shop running in the meantime'. ${ }^{675}$ The whole process was labelled as very quick with one member stating:

Imprest supply tends to also be a political debate... a chance to debate issues of the day rather than the particular content of the Imprest Supply Bill and maybe that's the way it will always be. It would be naïve to think that you could change that. ${ }^{676}$

Pallot regards imprest supply as not being a strict following of the principles of parliamentary control as the Act only limits the total amount that can be spent against appropriations with little further detail. ${ }^{677}$ Imprest supply was identified as causing problems for the AuditorGeneral's performing of the controller function. Specifically the Treasury reports as expenditure what would have been incurred against imprest supply. ${ }^{678}$ However, the audit of appropriations ensures that all expenses and capital expenditure incurred were against an appropriation or other authority.

\section{Supplementary Estimates}

The Supplementary Estimates process was likewise described as a formality and non-event. The process was identified as necessary because government expenditure will require adjustments as circumstances become clearer and to enforce parliamentary accountability over the changes. The process for scrutinising Supplementary Estimates was well regarded and described as 'smooth' and 'reasonably crisp'. ${ }^{679}$ The smoothness was linked to far less expenditure being pushed through the process than in the past. Supplementary Estimates are now seen as tidying up. Scrutiny was identified as adequate provided there is nothing 'particularly odious' in the Supplementary Estimates. ${ }^{600}$ There are rarely problems and as such they are given little attention. It was claimed that Supplementary Estimates do not receive sufficient attention. The problem according to a further member is that it is all a bit after the event' with the focus on 'what's around the corner, not what's behind the shoulder'. ${ }^{681}$ The FEC does not examine the Supplementary Estimates to the same extent as the Estimates due to the limited time available to consider them. They are examined 'well enough' with sufficient opportunity to raise issues. ${ }^{682}$

\footnotetext{
675 Anonymous MP, 23 January 2013.

${ }^{676}$ Anonymous MP, 31 November 2012.

677 Pallot commentary to Dale, 'The Budget Process', p. 251.

678 Pallot, 'Financial Management Reform', p. 43.

${ }^{679}$ Anonymous MP, 23 January 2013.

680 ibid.

681 ibid.

${ }^{682}$ Anonymous MP, 15 November 2012.
} 


\section{Financial Reviews}

Financial reviews are a vital feature for parliamentary accountability of government expenditure. Financial reviews were identified as the strongest aspect of parliamentary control and scrutiny by some interviewees, especially when compared to the Estimates examination. Unappropriated Expenditure in Appropriation (Financial Review) Bills was acknowledged with one member expressing surprise at how consistently departments operate within appropriations stating that 'there is certainly not a tradition or track record these days of massive unbudgeted expenditure' ${ }^{63}$ There was consensus that financial reviews are important for holding departments to account. According to one member the select committee examination provides 'the opportunity to give officials a bloody good knocking around and sometimes rightly so'. ${ }^{684}$ They provide the opportunity to 'expose incompetence, negligence and stupidity'. ${ }^{685} \mathrm{~A}$ further member elaborated that select committees are able to extract from officials where money has been spent, what errors were made and where they failed to obtain good value for money. Financial review reports vary greatly. McGee explains that some reports are 'pro forma' where the select committee informs the House that a review has been undertake and has nothing to report, and commonly there was no oral examination. ${ }^{686}$ Such a financial review was still seen as beneficial because it ensures that select committees are watching departments and other entities. ${ }^{687}$

Despite the generally high regard of the financial review process certain aspects were criticised. The select committee examination was viewed as having limited value by one member because the Minister is not required to appear. The member acknowledged that financial reviews relate more to operational matters, but since the Minister is ultimately responsible to Parliament for the department they should be required to appear before the committee. Financial reviews were understood to hold limited value to a further member because the expenditure and activity have already occurred. Members stressed that the financial review process is not an in-depth analysis of expenditure but more of a political event. However, in contrast to the Estimates examination government members are more willing to criticise the government because it is departments rather than the Minister under

\footnotetext{
${ }^{683}$ Anonymous MP, 28 November 2012.

${ }^{684}$ Anonymous MP, 6 November 2012.

685 Anonymous MP, 30 January 2013.

${ }^{686}$ McGee, Parliamentary Practice, p. 513.

687 ibid.
} 
examination. As pointed out by a government member they do not necessarily agree with all the decisions and actions of departments and as a result are more open to criticising them.

\section{Select Committees}

The select committee examinations were identified as where Parliament most effectively controls and scrutinises government expenditure. Select committees were held in high regard for their scrutiny of Estimates and financial reviews. It was even argued that it was only in select committees that any effective scrutiny occurred. The effectiveness of the select committee examinations was put down to their ability to examine government expenditure more closely than the House can through debate. It was recognised that despite select committees having greater ability than the House to examine government expenditure in detail 'there is just no way that any committee is going to be able to absorb every dollar this is being spent in every Vote that they're examining'. ${ }^{688}$ Select committees were described as an important information source for MPs with what is obtained in examination being used in the debates.

Select committee hearings with Ministers and official were seen as very important to interviewees. The hearings on the budget policy statement, the Estimates and financial reviews were identified as major events in the FEC's and other select committee's calendars. The comment was made by one member that the most effective work undertaken by select committees was the hearings. Hearings provide committees with an excellent opportunity to hold both the Minister and the department to account. The Estimates hearings in particular were highly valued because the Minister must appear before the committee. A senior member stated that requiring Ministers to appear had significantly improved accountability. Ministers are 'on the spot' with one member stating that 'there is nothing more frightening than going before a select committee with your feet to the fire'. ${ }^{689}$ The presence of the media does create a spectacle. Departments were claimed to 'work themselves into a tizz' to ensure that they are ready for hearings because 'they live in fear of being found wanting in front of a select committee'. ${ }^{60}$ The hearings 'lift the bar' in terms of expectations of departments with opposition MPs in particular criticising answers that are not up to the expected standard. ${ }^{691}$ Attempts to hide information typically get officials in more trouble than the actual issue according to one member.

\footnotetext{
${ }^{688}$ Anonymous MP, 23 January 2013.

${ }^{689}$ Anonymous MP, 31 November 2012; Anonymous MP, 30 January 2013.

${ }^{690}$ Anonymous MP, 23 January 2013.

691 ibid.
} 
The quality of examination was linked to the composition and dedication of the committee's members. Strong committees, it was argued, have a mixture of MPs with commercial knowledge, particularly accountants, and others with expertise in the committee's subject area. One member expressed the thought that select committees 'do not have the expertise, interest or skill' to provide the same level of scrutiny as the FEC. ${ }^{692} \mathrm{~A}$ further member argued that if the FEC were to carry out the examinations on its own there would be an overemphasis on reporting and accounting with less overall scrutiny. MPs, especially those in the opposition, must take full advantage of the select committee process. The effectiveness of the select committee process is linked to the determination of MPs particularly those of the opposition.

There was criticism of the select committee examinations. Hearings concentrate on aspects of Estimates and financial reviews that are politically contentious and not necessarily what should receive the most attention. The effectiveness of the hearings depends on the ability and desire of MPs to ask good questions. MPs focus on the trivial rather than the substantive according to one member. They concentrate on input controls or local issues with little attention given to the big picture or the long term impact of expenditure. ${ }^{693}$ Questions asked were viewed as having an excessive focus on new expenditure at the expense of requesting information on existing commitments. Questions in the Estimates hearing are frequently not relevant and would be more appropriate for the later financial review or a parliamentary question. Conversely one member argued that MPs got better answers by asking simple or naïve questions rather than more finite questions. The quality of the Estimates hearing is dependent on the competence of the Minister appearing before the committee. Ministers were criticised for reducing the time available for MPs to ask questions by making overly elaborate opening statements. Chairpersons must rein in a Minister that is wasting the committee's time.

Both government and opposition MPs were ridiculed for how they treated committee hearings. MPs in hearings either focus on making political attacks or defending the government rather than critiquing or seeking to improve government expenditure. Opposition MPs were seen to grab the opportunity to embarrass a Minister rather than ask about proposed expenditure. It was asserted that a crude but not inaccurate view of the select committee process was that opposition MPs' hunt for financial scandal. They ask questions with the goal of embarrassing the Minister. However, that was identified as a 'perfectly

\footnotetext{
${ }^{692}$ Anonymous MP, 31 November 2012.

${ }^{693}$ Norman, Obedient Servants, p. 160.
} 
proper role' for opposition MPs. ${ }^{694}$ A government member described the hearings as 'a big chance for the opposition to try and score points. But that's fine, that's part of the game'. ${ }^{695}$ Government MPs protect their Minister and avoid asking difficult questions instead putting forward 'patsies'. ${ }^{696}$ Select committees are rendered less effective by the strict controls that the government imposes on its caucus. Government MPs were described as hobbled because they were not meant to or even allowed to criticise the government. It was stipulated that government MPs just 'get told they don't stand up for themselves'. ${ }^{697}$ The media was indicated to have an important role here because they can publicise when government MPs are defending the un-defendable.

Effective select committee examination of the Estimates and financial reviews is dependent on a competent chairperson. Members identified that a competent chairperson acts independently and fairly allocates the overall time for committee business. They must balance the right of the opposition to hold the government to account and that of the government to have its business done. Chairpersons must appropriately allocate time or questions during the committee hearings. They must recognise that the hearings particularly on the Estimates are the 'opposition's day'. ${ }^{698}$ Former chairpersons believe that the opposition should have the majority of the time available with two thirds to three quarters identified as appropriate. Parties should be allocated their share of the time available prior to the hearing enabling MPs to 'run free' ${ }^{699}$ However, the common approach from chairpersons is to take questions from each party, seemingly at random, which constrains the ability of MPs to build momentum and ask an effective line of questioning. Opposition members criticised the government for using the chairpersonship or its majority to block or restrict the ability of the opposition to ask questions both during hearings and in the standard estimates questionnaires. They added that blocking the flow of information is inappropriate and a good chairperson must recognise that a competent Minister should not require protection. Opposition MPs can make the select committee 'awkward and unpleasant' if they believe they were hard done by. ${ }^{700}$

The FEC and the other select committees are under intense time pressure that constrains their ability to contribute to the control and scrutiny of government expenditure. McGee

\footnotetext{
${ }^{694}$ Anonymous MP, 6 November 2012.

695 Anonymous MP, 23 January 2013.

696 Anonymous MP, 23 October 2012.

697 ibid.

698 Anonymous MP, 30 January 2013.

699 ibid.

${ }^{700}$ Anonymous MP, 15 November 2012.
} 
identifies a lack of time as a 'great enemy of effective scrutiny'. ${ }^{701}$ The FEC's single three hour meeting on a Wednesday was described as 'tough'. ${ }^{702}$ It was emphasised by one member that a great deal more of MPs' time is consumed preparing for the meeting. Committees have quite limited time to examine the Estimates and financial reviews. The lack of time available is a further explanation for the many pro-forma financial review reports because committees must prioritise what they will examine in detail. They have tight reporting back dates and other business to perform particularly considering bills. Committees were noted for having vigorous debates on how they will allocate their time. Select committees were identified as effective at prioritising their work. The FEC was seen to do a thorough job given the time available. The time available for the hearings is acceptable provided the occasions are recognised as the opposition's day. The opposition has complained occasionally when they felt insufficient time was allocated to a committee hearing on the Estimates. ${ }^{703}$ However, the frequency of hearings was questioned with one member arguing that these should occur more often.

\section{Controller and Auditor-General}

The Auditor-General was held in high regard by members. The Auditor-General was set out by one interviewee as 'an important safeguard, almost a quasi-constitutional role in some sense'. ${ }^{704}$ The Auditor-General's independence and its status as an officer of Parliament was valued and perceived as critical by interviewees. The effectiveness of the Auditor-General was attributed to the capability and judgement of the office holder. The Auditor-General is highly influential and has a significant impact on the public sector particularly in relation to how an organisation is set up and its culture. The power of the Auditor-General comes from access to information and its reporting powers, especially due to the publicity its reports can receive. ${ }^{705}$ Power and influence is generated through the audit and control functions. Members had no major qualms with the Auditor-General's performance but did identify issues that constrain, or do not effectively assist, Parliament in controlling and scrutinising government expenditure.

The Auditor-General's roles and powers are sufficient but the office is under-resourced. The Auditor-General has 'a very wide and solid mandate' through the Public Audit Act 2001

\footnotetext{
${ }^{701}$ McGee, The Overseers, p. 73.

${ }^{702}$ Anonymous MP, 31 November 2012.

${ }^{703}$ Social Services Committee, '2010/11 Estimates For Vote Housing', 28 July 2010, http://www.parliament.nz/resource/0000114117 (18 September 2012), p. 5.

${ }^{704}$ Anonymous MP, 31 November 2012.

${ }^{705}$ Norman, Obedient Servants, p. 186.
} 
and the PFA to undertake its work. ${ }^{706}$ Roles and powers are not the issue according to several members. The real issue is the level of resources available and how they are used. The Auditor-General and appointed auditors were described as 'stretched'. ${ }^{707}$ There was a strongly held view that the Auditor-General could do more but will require extra funding to undertake further work. With Parliament and the government determining through the Officers of Parliament Committee the level of resources for the Auditor-General MPs must decide what they are prepared to fund.

\section{Audit Function}

The Auditor-General was understood to do an excellent job of undertaking the audit function but there are issues. The high standard of auditing was linked to the usage of Audit New Zealand as well as private sector auditors. It was stressed by one interviewee that New Zealand has a 'clean, effective public sector'. ${ }^{708}$ There will always be issues found but they are around the edges. However, there were some members that believe the Auditor-General misses problems. Although satisfied with the Auditor-General's performance one member felt there was room for improvement arguing that the office 'lost their way' ${ }^{709}$ The focus of auditing was overly concentrated on higher level scrutiny rather than at the lower 'grass roots' level that ensures a culture in the public sector of avoiding poor quality expenditure. ${ }^{710}$ The notion was supported by several other members that want more emphasis placed on identifying waste and failures to get value for money. The aforementioned member put forward the case that ideally the public should be able to inform the Auditor-General of potential waste and have confidence that their concern will be investigated. The member was adamant that an enhanced ability for the public to raise issues would make the public sector spend money more wisely. There were concerns from members that the Auditor-General is commenting on issues beyond its area of expertise.

Further issues with auditing relate to cost and the documents that are produced. There were concerns from many interviewees that the cost of auditing is too high especially for small entities. One interviewee questioned whether it was necessary to audit small public entities every year such as schools. Auditing should fit the size and risk of organisations. It was recognised that a major challenge for the Auditor-General is balancing accountability

\footnotetext{
${ }^{706}$ Interview with anonymous interviewee, 14 December 2012.

${ }^{707}$ Anonymous MP, 8 November 2012.

708 Anonymous Interviewee, 14 December 2012.

${ }^{709}$ Anonymous MP, 6 November 2012.

710 ibid.
} 
and transparency with the costs placed on departments and entities to meet reporting requirements. The Auditor-General was perceived as overzealous with compliance documents. The documents that departments must produce were too difficult to comprehend because they are overly long, formulaic and bureaucratic. One member questioned whether growing documentation requirements actually improved accountability. The onus is on Parliament to determine the level of information and assurance it wants from the AuditorGeneral. If Parliament believes that auditing is excessive it should move resources to other parts of the system.

Performance audits and inquiries were highly respected parts of the Auditor-General's work. They were described as valuable tools that enable the Auditor-General to investigate a broad range of issues including those requested by MPs and the public. Inquiries and performance audits were identified as being thorough and performed to a high standard. Opposition members in particular appreciated the subsequent reports, believing they are important to holding the government and departments to account. The opposition were identified as using reports from Auditor-General inquiries to hold the government to account. The Auditor-General must balance its resources, priorities and overall work program to determine what inquiries it will undertake. The Auditor-General is unable to investigate every issues referred to it due to the limited resources available.

\section{Controller Function}

There was satisfaction with the Auditor-General's performing of the controller function. The controller function was of little concern to MPs but they did recognise its immense importance. The Auditor-General on the whole carries out the control function adequately according to a senior member, although there may be times when a member or Minister may think that a decision is adverse to their interests. A further member commented more broadly arguing that expenditure is well controlled with the public sector very capable at budgeting, accounting and reporting. There should be 'reasonable satisfaction' that public money is properly appropriated and spent in accordance with what Parliament has authorised. ${ }^{711}$ The powers available to perform the controller function are adequate. The culture of government is very important to control. It was stressed that it is not just about formal rules but strong traditions and conventions. Conventions according to one member are undervalued particularly those that ensure freedom from corruption. Newberry and Pallot insist that the

\footnotetext{
${ }^{711}$ Interview with anonymous MP, 15 November 2012.
} 
controller function has been eroded. ${ }^{712}$ They argue against the change to the Treasury reporting system. They identify the reporting system as overly reliant on the assurances of Treasury labelling it as poor governance and constitutionally unsound. ${ }^{713}$ However, the Auditor-General has powers that enable it to check the reports' accuracy and they neglect the audit of appropriations that reinforces the reporting requirements. ${ }^{714}$ The Auditor-General has expressed confidence in how the function is now performed and stated that the old method was made ineffective by accrual appropriations. ${ }^{715}$ Although it is no longer performed the traditional way, the controller function is performed effectively.

\section{Relationship and Reporting to Parliament}

The Auditor-General's relationship with Parliament is important and was generally recognised as being in good health. The relationship between the Auditor-General and Parliament was highly commended and respected with members describing it as 'constructive', 'independent but collegial' and 'close and effective'. ${ }^{716}$ It is widely recognised that the Auditor-General should have an effective relationship with the PAC, in New Zealand's case the FEC. ${ }^{717}$ The Auditor-General in line with New Zealand practice has a close relationship with all select committees ensuring better engagement with Parliament as a whole. The connection between the Auditor-General and select committees, especially the FEC, was identified as being particularly good. The Auditor-General received special praise for its relations with select committee chairpersons. A senior member claims that select committees are building on a historically good relationship by making greater use of the Auditor-General as an advisor.

The assistance provided by the Auditor-General as an advisor to select committees was commended. The Auditor-General was recognised as a valuable and useful resource for members providing assistance of a high standard. Oral briefings were viewed as immensely important and help to build 'understanding' and 'maturity' in the relationship. ${ }^{718}$ They provided 'colour and richness' that are difficult to convey in written reports. ${ }^{719}$ The oral and

\footnotetext{
712 Newberry and Pallot, 'Wolf in Sheep's Clothing?', p. 272.

713 ibid.

${ }^{714}$ Auditor-General, 'Central Government', pp. 56-57.

715 ibid.

716 Anonymous MP, 6 November 2012; Anonymous MP, 2 November 2012; Anonymous interviewee, 14 December 2012.

${ }^{717}$ McGee, The Overseers, pp. 11-12; Riccardo Pelizzo, Rick Stapenhurst, Vinod Sahgal and William Woodley, 'What Makes Public Accounts Committees Work?', p. 789.

${ }^{718}$ Anonymous interviewee, 14 December 2012.

719 ibid.
} 
written briefings on the Estimates and financial review documentation are appreciated by members. It was acknowledged that MPs are unable to read and process all of the information in time while additionally providing a valuable second opinion. The briefings were recognised for suggesting areas that the committee may like to explore and for providing potential lines of questions. However, Norman notes that usually the Auditor-General's briefings are put to one side with questions instead focusing on embarrassing the Minister. ${ }^{720}$ The briefings for the financial reviews were criticised for having too great an emphasis on issues relating to the controller function. Members would like more information on waste, value for money and outcomes. Members appreciate that the Auditor-General avoids overstepping its authority in the briefings. The advice provided was viewed as limited by one member because it does not comment on government policy. However, other interviewees firmly believe that it is inappropriate for the Auditor-General to comment on government policy.

Select committees were criticised for not being sufficiently receptive of the AuditorGeneral's reports. Select committees ideally consider the Auditor-General's reports. They receive an oral briefing from the Auditor-General's staff and proceed to investigate the issues raised in the report. The select committee subsequently produces a report for the House describing their examination and how the issues will be addressed. The process was demonstrated to show a clear process of parliamentary accountability. However, select committees frequently decline briefings. The FEC in particular has a reputation for rarely examining reports from the Auditor-General. ${ }^{721}$ For the four years through to June 2005 the FEC did not review, or undertake a follow-up inquiry, on any report from the AuditorGeneral. ${ }^{722}$ The issues identified by the Auditor-General are often left without scrutiny from Parliament which was labelled as frustrating by one interviewee. It was acknowledged by one member that the Auditor-General finds it frustrating that the office's reports receive little attention from select committees. Time restrictions and wanting to focus on other areas are the common reasons for reports not receiving greater attention.

\section{Finance and Expenditure Committee}

\section{Role and Status}

\footnotetext{
${ }^{720}$ Norman, Obedient Servants, pp. 158-159.

${ }^{721}$ Jacobs, Jones and Smith, 'Public Accounts Committees in Australasia', p. 34.

722 ibid, p. 40.
} 
The FECs significant and broad role was identified by interviewees. The committee was recognised as New Zealand's equivalent to a Public Accounts Committee (PAC) but with a significantly wider role. The FEC was described as a 'unique hybrid' with a number of 'multi-layered' roles. ${ }^{723}$ It was put by interviewees that the FEC is responsible for the parliamentary oversight of government expenditure and revenue, monetary policy and economic policy. It examines and reports on the 'macro, large view picture'. ${ }^{724}$ The FEC not only co-ordinates the Estimates and financial review examinations but is crucial to setting the tone for the other select committees. The committee is expected to have a broader focus than just its primary business. The committee must hold a more strategic view in relation to the financial management model. The FEC's roles as a subject committee were also acknowledged including consideration of tax and government finance legislation and undertaking inquiries.

The FEC was recognised as holding a pre-eminent position amongst Parliament's select committees with capable members. The committee was labelled as the 'premier' select committee. ${ }^{725}$ It was even claimed that the FEC is 'the most powerful committee in Parliament'. ${ }^{726}$ The FEC's power was linked to its high profile including the media coverage it receives for its various hearings. The committee's supremacy also comes from its position as the point where all financial and expenditure matters must pass. Its power and influence is reflected by most, if not all, parties wanting representation on the committee. The FEC was distinguished for bringing together capable and aspirational government backbenches and hard hitting experienced opposition MPs. Many members have ministerial experience and the chairperson is identified as a 'stepping stone' to becoming a Minister. ${ }^{727}$ The committee was understood to have more financially literate members than other select committees. It was stressed by the interviewee that that was not criticism of the membership of the other select committees but a reflection that MPs have different strengths.

The FECs performance was highly rated. While members stressed the importance of the FEC they were quick to acknowledge that for the Estimates and financial reviews it is the other select committees that do most of the grunt work. The committee received high praise with one member asserting that there is 'a reasonably high standard of people on the

\footnotetext{
${ }^{723}$ Anonymous MP, 28 November 2012.

${ }^{724}$ Anonymous MP, 6 November 2012.

725 Anonymous MP, 31 November 2012; Anonymous MP, 23 January 2013.

${ }^{726}$ Anonymous MP, 30 January 2013.

${ }^{727}$ Kerry Jacobs, Kate Jones \& David Smith, 'An Analysis of the Sources of Public Accounts Committee Inquiries: The Australian Experience’, Australasian Parliamentary Review, Vol. 25, No. 1 (Autumn 2010), p. 21.
} 
committee and they're all quite diligent and do a good job'. ${ }^{728}$ There was some modesty from a further member who described the FEC as adequate and competent. Members saw the FEC as effective at scrutinising the fiscal responsibility documents. The committee was believed to carry out its work such that the opposition got a fair opportunity to question and acquire the information it requires while allowing the government to have its business completed.

\section{Success Factors}

The FEC is at the centre of Parliament's control and scrutiny of government expenditure. With the FEC having a pivotal role it must be fully capable of undertaking its work. Pelizzo, Staphenhurst, Sahgal and Woodley are recognised for identifying a wide range of factors that influence how successful a PAC is at performing its duties. ${ }^{729}$ They argue that in regard to formal powers PACs should have a broad mandate and freedom to choose what they investigate, be able to examine both past and present expenditure, should check the government's implementation of its recommendations, and have a good working relationship with the Auditor-General. ${ }^{730}$ There are also key behavioural factors of members and the functioning of the committee that influence PACs effectiveness: the extent that members read the documentation and prepare for meetings, whether transcripts are produced, if conclusions and recommendations are published, and if the media and the public are involved. ${ }^{731}$ They identify that PACs must have 'adequate staff and independent sources of information' and function in a non-partisan fashion. ${ }^{732}$ Pelizzo and Stapenhurst further identify that PACs may be restricted by the government lacking interest in or having an aversion to legislative oversight. ${ }^{733}$ The FEC's leadership position results in the analyses having value for accessing the capability of all select committees. Several of these factors have been examined earlier. The following section considers the other factors.

\section{Inquiries}

The FEC and the other select committees were identified by interviewees as not undertaking an adequate number of inquiries. The FEC is not renowned for undertaking inquiries as made evident by it not conducting a single inquiry either on its own initiative or on referral from

\footnotetext{
${ }^{728}$ Anonymous MP, 28 November 2012.

${ }^{729}$ Kate Jones and Kerry Jacobs, 'Public Accounts Committees, New Public Management, and Institutionalism:

A Case Study', Politics \& Policy, Vol. 37, No. 5 (2009), pp. 1026-1027.

${ }^{730}$ Pelizzo, Stapenhurst, Sahgal and Woodley, 'What Makes Public Accounts Committee Work?', p. 789.

731 ibid, pp. 789-790.

732 ibid, p. 790.

${ }^{733}$ Pelizzo and Stapenhurst, 'Strengthening Public Accounts Committees', p. 392.
} 
the House from July 2001 to June $2005 .^{734}$ The FEC's workload instead is concentrated on Estimates and financial review examinations, and considering bills, petitions and other matters. ${ }^{735}$ Several interviewees were of that mind-set, believing the FEC undertakes fewer inquiries than it did previously. The launching of inquiries is dependent upon the government who can use its majority to block them. Successive governments have strangled select committees by blocking inquiries requested by the opposition using their majority. Inquiries are blocked to prevent political embarrassment and to ensure that committee time is not diverted from government business. The ability of select committees to undertake inquiries reflects their independence from the executive and Caucus. ${ }^{736}$ The FEC's inability to undertake inquiries suggests that the government has too much influence on the select committee system. Several members expressed that the FEC's time would be better spent undertaking inquiries. Committees need the ability to investigate poor governance but inquiries were identified as more useful if they were into non-partisan issues.

\section{Government and Reports}

The extent that the FEC's reports are taken seriously by the executive and departments was disputed. It was argued by the KPMG report that PACs are only seen as effective if their recommendations are implemented. ${ }^{737}$ Departments were thought to take reports from the FEC very seriously. Several members were of the opinion that the Cabinet and departments follow the FEC closely with reports receiving thorough consideration. Highly critical recommendations from the FEC would be concerning. Members noted that the government must respond to various reports produced by select committees but not those on the Estimates and financial reviews. Several members commented that the FEC to an extent follows up on its reports. Reports presented to the FEC were identified as following up on previous reports and it was clear if an issue had been adequately addressed. It was stated that control issues are followed up in subsequent audit reports. There were more critical observations of the government's consideration of FEC reports. It was argued that FEC reports 'tend to get wrapped into a general melee, it is a bit unreasonable to expect otherwise'. ${ }^{738}$ A more critical opinion was that the government does not need to worry about FEC reports because they can steer findings through their majority.

\footnotetext{
734 Jacobs, Jones and Smith, 'Public Accounts Committees in Australasia', p. 40.

735 ibid.

${ }^{736}$ McRae, A Parliament in Crisis, p. 17.

${ }^{737}$ KPMG, The Parliamentary Public Accounts Committee, p. 43.

${ }^{738}$ Anonymous MP, 31 November 2012.
} 


\section{Reports}

There were stark contrasts in opinion on the reports of the FEC and the other select committees. Reports from the FEC were described as holding greater significance than those from the other select committees because of its status. The FEC was viewed as having a reputation for producing high quality reports with some being 'quite profound in terms of their influence on subsequent policy'. ${ }^{739}$ Other members were more critical describing them as low quality due to a poor process. There was cynicism from a further member who doubted that the FEC's reports have much influence. The FEC was seen as pedantic about the wording of its reports given their small audience. The FEC does include transcripts of its hearings in many of its reports. The argument is made in the KPMG report that PACs reports are stronger when they have unanimous support from committee members. ${ }^{740}$ Unanimity provides certainty to Parliament about the committee's conclusions and bolsters the recommendations. The KPMG report surmises that 'it is better to negotiate and compromise in the drafting of committee recommendations than to issue a report with dissenting views'. ${ }^{741}$ Although the ability to submit a minority view is important the privilege is currently abused. It was recognised that a report's impact is diminished when a number of minority reports are attached to it. They should only be used where there is a profound disagreement with the majority position.

\section{Public Access}

The current level of access for the media and the public to select committee proceedings is appropriate. Pelizzo, Staphenhurst, Sahgal and Woodley argue that 'media coverage can provide committee members an incentive to perform their oversight function effectively'. ${ }^{742}$ Their argument is too simplistic and does not fit with the evidence presented by the FEC. Interviewees were satisfied with, and saw value in, the current level of public and media access that generally has select committees open for the hearings and closed for the deliberations amongst MPs. The media were described as having the role of 'policemen' ${ }^{743}$ A public hearing provides the opposition with the opportunity to embarrass the government and gives the public and the media the opportunity to critique the information obtained

\footnotetext{
${ }^{739}$ Anonymous MP, 31 November 2012.

${ }^{740}$ KPMG, The Parliamentary Public Accounts Committee, p. 40.

741 ibid.

${ }^{742}$ Pelizzo, Stapenhurst, Sahgal and Woodley, 'What Makes Public Accounts Committee Work?', p. 790.

${ }^{743}$ Anonymous MP, 15 November 2012.
} 
through questioning. Members were adamant that it helps not having the public and the media in attendance. There is a significant increase in politicking due to the opportunity to score points and officials are not as frank with the committee. Select committees meeting in private enable MPs to work together and find compromises. Interviewees did not believe that more open select committees would improve the quality of democracy or the accountability of government expenditure. There was little support for televising select committees as that would further increase partisanship and point scoring. Any televising should be limited to meetings that are already open to the public.

\section{Committee Staff and Resources}

There was broad satisfaction with the level of staff and resources provided to the FEC and the other select committees. Staff support provided to select committees has been criticised by Pallot and Newberry. ${ }^{744}$ Interviewees expressed confidence in the level of assistance provided to MPs but generally would like more. Staffs from the Office of the Clerk were for the most part identified as very capable by members. They are strictly secretaries that provide administrative assistance and ensure that committees are aware of their roles and proper procedure. It was reiterated by a number of members that the FEC and the other select committees receive excellent independent advice from the Auditor-General. Party research units and the Parliamentary Library also serve as important information sources. Members specified that when they require further advice specialists can be brought in for one off assistance. Contracting in extra specialists is more efficient than hiring further permanent staff. Specialist advisers are utilised effectively for briefings on the monetary policy statement and for tax legislation. Several members were of the opinion that the FEC should have extra support staff. It was argued by one member that the main limit on Parliament's ability to control and scrutinise government expenditure was the lack of resources available to MPs.

\section{Partisanship}

The FEC typically operates in a partisan fashion although it is capable of being non-partisan. There was near unanimity that the FEC is a partisan committee. It was even argued that the FEC is the single most partisan select committee. However, there was a more positive view that the FEC tends to work fairly collaboratively but given the nature of some of the issues it

\footnotetext{
${ }^{744}$ Newberry and Pallot, 'Wolf in Sheep's Clothing?', p. 270.
} 
considers there will occasionally be partisan splits. The hearings are dominated by party politics. It was explained that the FEC will inevitability feature a high level of partisanship because of the adversarial nature of Parliament. It is unavoidable that the contentious issues addressed by the FEC will result in partisanship. In many cases partisanship was even seen as desirable. It was identified that the level of partisanship in select committees is determined by its membership, the nature of the business in front of it, and if the proceedings are open to the public. There was recognition that select committees are where the 'real work' of Parliament occurs and that should result in efforts to balance out the level of partisanship. ${ }^{745}$ Aspects of the FEC acting in a non-partisan way were acknowledged such as entities failing to meet accounting standards.

\section{Formation}

The FEC and the select committee system as a whole have an effective structure. The current select committee structure that has the FEC performing a leadership role was broadly approved of by interviewees. The lack of a specialist PAC in the opinion of one member prevents the thorough examination of Auditor-General reports and in-depth inquiries. However, members that have attended international PAC conferences were comfortable with the FEC model. It was seen to ensure a more specialised and knowledgeable committee that was more appropriate given the size of Parliament. A separate PAC would split up the small group of MPs that have a comprehensive understanding of finance and economics. Referring the Estimates and financial reviews across the select committees is appropriate because of the importance of the function to Parliament. It ensures that more MPs are used to examine expenditure with their specialist subject area knowledge compensating for not having the same level of financial expertise. Such knowledge is important for evaluating the delivery of outcomes. Having a separate PAC to undertake financial reviews was rejected. Estimates and financial reviews are intertwined with knowledge carried between examinations. They should be undertaken by the same committee. Splitting off financial reviews to a special committee would reduce knowledge accumulation.

The FEC should continue to have a government MP as its chairperson. Chairpersons are ultimately responsible for the effectiveness of a PAC. ${ }^{746}$ Most members were adamant that the FEC must have a government chairperson. The structure of the select committee system, the FECs broad role and its premier status makes a government chairperson desirable

\footnotetext{
745 Anonymous MP, 23 October 2012.

${ }^{746}$ KPMG, The Parliamentary Public Accounts Committee, p. 6.
} 
if not a necessity. An opposition chairperson was identified as appropriate if New Zealand had a more standard PAC. It was stressed by several members that governments must be able to govern. Opposition members in particular acknowledged that a government chairperson is appropriate to ensure that its business flows through the committee. An opposition chairperson was perceived as risky because potential abuse of the position could create paralysis, particularly due to the FEC's mechanical and deliberative role. It was noted that opposition MPs do serve as chairperson of other select committees. One member interviewed argued that it is character rather than party allegiance that is important. It is a matter of perspective according to one member. The opposition would prefer one of their MPs as chair, while the government would want one of their backbenchers to hold the post. Government chairpersons are generally highly capable MPs on track to becoming a Minister and they want to prove themselves.

There were some interviewees who were not adverse to the FEC having an opposition chairperson. A government chairperson can be perceived as compromising a committee's independence, including limiting its inquiries. There is the counter-argument that a government chairperson has greater access to the executive and is able to add extra weight to the committee recommendations. ${ }^{747}$ It was claimed by a member that given the few checks and balances on the government an opposition chairperson of the FEC could be appropriate. Several members stressed that a chairperson's ability to perform their duties is dependent on the MPs integrity and not whether they were from the government or the opposition. They recognised that an obstructive chairperson would be a major problem. An opposition chairperson must still have the fundamental objective of assuring that the government's business is done. It was contended that most MPs, whether government or opposition, take the responsibility of holding a chairpersonship seriously and this ensures that they perform the job adequately. There was apprehension from one member who argued that an opposition chairperson would have little impact without an opposition majority.

There was strong support for the FEC continuing to have a majority of government MPs due to the committees' immense importance. For practical purposes members argued that the FEC must have a government majority. Possessing a government majority on the FEC is crucial to ensuring that the government's business progresses in a timely manner. It was recognised by several members that a great strength of the New Zealand parliamentary system is that governments are able to govern. It was argued that an opposition majority on

747 Jacobs, Jones and Smith, 'Public Accounts Committees in Australasia', p. 37. 
the FEC could effectively handicap the ability of the executive to perform the business of government. Opposition members stressed that they would certainly want a government majority if they were in office. However, one member was adamant that the FEC is ineffective because of the government majority which was identified as turning the committee into a rubber stamp. There must be a balance between checks and balances and ensuring the government's capacity to govern; an opposition majority risks swinging the balance too far toward the former.

The current size of the FEC with 12 members was identified as appropriate with no desire for change. A larger FEC would be inefficient, unwieldy and unworkable. There was no wish to reduce the size of the FEC. It was recognised that given the importance and stature of the FEC all parties should be represented, or that they at least have the option. The argument was made that it is not about the number of MPs but their quality, their approach to undertaking the paperwork and their understanding of what the committee's work means. It was contended by a further member that a far larger Parliament can have MPs who dedicate their careers to committee work and are more thorough as a result. A small Parliament prevents such specialisation with a small pool of MPs focusing on getting into the Cabinet. It has become apparent that select committees, particularly the FEC, have frequent membership changes. McGee reasons that committees should have a stable membership with MPs expected to remain on the committee for the full length of the parliamentary term. ${ }^{748}$ Constant membership changes can result in the loss of knowledge. ${ }^{749}$

The FEC does not use subcommittees to help undertake its work and certainly not to the same extent as the Public Expenditure Committee. McGee argues that PACs can use subcommittees to perform particular tasks to counter their time constraint. ${ }^{750}$ Having all select committees able to initiate their own inquiries has resulted in less pressure on the FEC when compared to its predecessor to form subcommittees to carry the load. The FEC did have a subcommittee from 2000 to 2002 to examine reports from the Auditor-General. ${ }^{751}$ It was seen as a 'useful development' and part of an ideal process by the Auditor-General for consideration of its reports. ${ }^{752}$ Subcommittees are used to address a large number of public submissions on bills. However, it was argued that it is better to meet as a whole committee because of the friction created by MPs arguing over what submissions they did or did not

\footnotetext{
748 McGee, The Budget Process, p. 71.

749 ibid.

${ }^{750} \mathrm{McGee}$, The Overseers, p. 73

${ }^{751}$ Palmer and Palmer, Bridled Power, p. 127.

752 ibid.
} 
hear. According to one member, establishing subcommittees is rare and difficult due to the introduction of MMP and minor parties. Minor parties want equal representation to ensure that they do not miss out. The 'game' of equal representation has resulted in subcommittees inevitability being used less. ${ }^{753}$ Generally there was no demand for making greater use of subcommittees. However, several members saw subcommittees as an effective way to undertake more inquiries. Such inquiries could involve general housekeeping such as tidying up glitches, inefficiencies or policy mistakes according to one member. The major issue was government resistance if they saw too much political risk.

\section{Conclusion}

Parliament performs the role of controlling and scrutinising government expenditure less than optimally. Parliament has adequate control of government expenditure but effective control is primarily due to the Auditor-General's proficient performing of the audit and control functions. The appropriations system, Budget documentation and the financial statements and accounting system also facilitate Parliament's solid performing of the control aspect. Parliament as such has quality machinery in place to ensure that the government only spends public money as it has approved. Parliament is however somewhat deficient at scrutinising government expenditure. Government expenditure is primarily scrutinised through the various parliamentary debates and select committee examinations. The opportunities to debate government expenditure in the House are often wasted by MPs. Select committee examinations do feature some quality scrutiny, particularly for the financial reviews, but they are often not properly used either. Therefore, MPs themselves are primarily responsible for the imperfect scrutiny of government expenditure. Reform is desirable to improve Parliament's control and scrutiny of government expenditure. The next chapter will provide recommendations that have the potential to improve Parliament's performance.

${ }^{753}$ Anonymous MP, 6 November 2012. 


\section{Chapter Five: Recommendations and Conclusion}

\section{Introduction}

With Parliament being somewhat deficient at controlling and scrutinising expenditure it is necessary that reforms be introduced to improve its performance. The function has been recognised as important through its history, in academic debate and by current MPs. The previous chapter established that Parliament is quite effective at controlling government expenditure but was found wanting when it came to scrutiny. With the function's recognised importance it is appropriate that Parliament reviews and reforms how it performs the role. The following chapter provides a number of reform options, envisaged from the previous chapters as well as suggestions and requests from interviewees that have the potential to improve Parliament's performance. Potential reforms discussed range from being quite specific, to the identification of more general issues that do not have more finite solutions. But first opportunities for further research are discussed.

\section{Opportunities for Further Research}

There are further areas that could be researched relating to this thesis. A complementary avenue for research is to examine the procedure and practice used by foreign Parliaments to examine government expenditure and determine what lessons can be learnt for the New Zealand Parliament. Particular emphasis should be placed on other countries of the Westminster tradition such as the United Kingdom, Canada and Australia. However, examining the work of other foreign legislatures will most likely also be beneficial. Research could also be taken into broader areas relating to Parliament and government finance. It may perhaps be of interest to analyse Parliament's control and scrutiny of government revenue, lending and borrowing. In addition, consideration may feasibly be given for research into the accountability of local government expenditure.

\section{Support for and Limitations on Reform}

There was support for making some changes to Parliament's procedure and practice but there are limitations on suggested reforms. One member stated that is 'absolutely relevant and worthwhile' reviewing the current systems that are in place. ${ }^{754}$ Even those who believed that Parliament is effective at performing the function saw room for improvement. The argument

${ }^{754}$ Interview with anonymous MP, 28 November 2012. 
was quite correctly made that there are no quick fixes. Instead the contention was made by several interviewees that a path of steady, incremental improvement is more appropriate. It was suggested that New Zealand already has a strong and mature platform, it is now about how that can be improved. The potential cost of reform was questioned particularly if only marginal improvements would be achieved. A further limit on reform is the significant time pressure already on Parliament and MPs which limits the amount of further work that can be undertaken. There were expressed doubts from members that there is very much scope for increasing the amount of time Parliament allocates to the function. MPs already have an exhausting workload, with commitments to Parliament, their party and their constituency as well as their family. It was stressed that without that time beyond the House MPs would become a subset of society and not a representative group of politicians. There must be caution to ensure that attempts to improve either control or scrutiny do not overly jeopardise the ability of Parliament to perform its other roles.

\section{Members of Parliament}

\section{Transform ability and willingness of MPs to perform the function}

Improving Parliament's ability to control and scrutinise government expenditure must concentrate on improving MPs' ability and willingness to perform the role. One senior MP commented that:

The next area of change is focusing better the minds of parliamentarians on their role as controllers...I don't think that's sufficiently widely understood or appreciated at the moment and consequently lots of opportunities for really asking hard questions about expenditure or proposed expenditure go missing. ${ }^{755}$

The member added that the necessary machinery to enable MPs to perform the role is in place. How that machinery is used is the problem. The issue was expanded upon by a further member. It was argued that for Parliament's performance to improve, MPs must exercise integrity, and they must not just play political games. Instead their focus must be on the substantive, what is in the country's best interest, rather than the trivial. It was surmised that that is a case of MPs better determining when they should be serving as parliamentarians or as instruments of their parties. The member did however acknowledge that it is good and healthy for MPs to have differing points of view. The fundamental problem is the nature of our parliamentary democracy that results in Parliament having a confrontational and

\footnotetext{
${ }^{755}$ Interview with anonymous MP, 31 November 2012.
} 
adversarial culture. It has too much anarchy. For scrutiny to improve the adversarial nature of Parliament must be toned down. The select committee process in particular could benefit from a reduced level of partisanship. Changing the political culture is an insurmountable task, but two reforms could have some impact.

\section{Reduce the Government's ability to control their Backbenchers}

The executive's dominance over government backbench MPs should be reduced to allow them to contribute to effective scrutiny. It is an irony that for parliamentary control and scrutiny of government expenditure to improve the government must be more open to criticism. The select committee process, in particular, would be more effective if government MPs were given the ability to operate as parliamentarians with the freedom to criticise the government. The extent to which the government is able to dominate select committee proceedings through pressure exerted on chairpersons and their majorities should be reduced. Governments must be able to have their business proceed through select committees but that should not constrain the ability of opposition MPs to ask questions. There was a request from one member that a new Standing Order be introduced to reduce the ability of government chairpersons and majorities to refuse to put forward questions. Opposition MPs must be able to delve into areas of the Estimates and financial reviews that they believe are of interest. However, such a proposed rule change is unlikely to work in practice. The emphasis instead should be put on changing attitudes towards performing the function.

\section{Increase the size of Parliament and Extend the Length of the Parliamentary term}

Increasing the size of Parliament and the length of the parliamentary term could theoretically help address the aforementioned problems. Parliament's performance could improve with additional MPs who are of sufficient calibre and are committed to performing the function. A larger Parliament of 140 or 150 MPs is associated with a more independent government caucus that is less subject to pressure from Cabinet. ${ }^{756}$ More MPs would allow for a greater number of select committees opening up the possibility for alternative structures. ${ }^{757}$ Furthermore, there is the increased likelihood that backbenchers would be more likely to identify a parliamentary career as a quality committee member as a valuable alternative to serving as a Minister. Increasing the length of the parliamentary term from three to four years

\footnotetext{
${ }^{756}$ Egan, Wakelin and Yuill, Parliamentary Control, pp. 60-62; Royal Commission on the Electoral System, Report of the Royal Commission on the Electoral System: Towards a Better Democracy (Wellington: Government Printer, 1986), pp. 122-124.

${ }^{757}$ Royal Commission on the Electoral System, Report of the Royal Commission, pp. 124-126.
} 
has distinct potential benefits too. A longer term would provide MPs with a more appropriate timeframe from which to judge the government's policies, particularly as stated in their desired outcomes. ${ }^{758}$ The shift could also result in MPs focusing more on serving as parliamentarians because with elections further away there is the reduced incentive to focus on point scoring. ${ }^{759}$

\section{Estimates Documentation}

\section{Review Estimates Documentation}

The Estimates documentation requires review to ensure that it fully enables MPs to scrutinise the government's expenditure proposals. Several interviewees requested that efforts be made to improve the Estimates documentation. The various documents must meet the needs of Parliament. Their content must be made as easy to understand as possible and be presented in a straightforward format. The availability of the Budget and Estimates documentations in electronic form has improved access and digestibility. It would be appropriate to take advantage of having documentation in electronic format. The various documents, including those from previous years, could be linked together to reduce the extent that MPs and the public need to sift between sources and to ensure that both receive the full picture from the information available. Improving accessibility is necessary to better engage the public and subsequently improve the quality of debate on government spending. Several members, those from the opposition in particular, would appreciate more time to examine the Estimates and the other Budget documents. The problem with increasing the time to examine documentation is the impact that would have on the supply process, and the subsequent impact on Parliament's, and particularly the Auditor-General's contribution to, the control of government expenditure. The content of the standard estimates questionnaire should continually be examined for any new trends in information that MPs wish to have in the Estimates.

There must be caution when making changes to Estimates documentation. Modifying Estimates documentation to improve the scrutiny of government expenditure has the potential risk of over simplification. Estimates information that is too simple could jeopardise Parliament's ability to exert adequate control, because appropriations are not specified in enough detail. There has been criticism of attempts to move away from the current set of

\footnotetext{
758 ibid, p. 158.

759 ibid, p. 159.
} 
documents. Newberry and Pallot argue for the continued usage of the current Estimates and Supplementary Estimates documentation. They say that they are a 'flexible, adaptable means of presenting information to Parliament and the public in a useful and meaningful form'. ${ }^{760}$ The evidence from interviewees suggests that that is not entirely the case. They are rightly nervous about changes, but that does not mean Parliament should be held back by existing practice. They do acknowledge that innovation in how information is presented is desirable, but that does not mean that the existing requirements need be compromised. Therefore, the key is innovation in presentation to improve comprehensibility and speed of consumption, rather than decreasing the level of detail.

\section{Improve Outcome Specification and Measurement}

Improving the specification of outcomes in Estimates documentation and reporting on their delivery in annual reports should advance the ability of MPs to scrutinise government expenditure. Several members argued that outcomes must be more clearly stated. It was argued that MPs are more effective at critiquing proposed expenditure outcomes, and the government's subsequent ability to deliver them, rather than examining output and control issues. Focusing on outcomes would be a more effective use of Parliament's time and would make better use of MPs subject area expertise. There was a request for documentation that better allows for the "consideration of opportunity cost of spending and bang for the buck as opposed to just volumes of black letter accounting' ${ }^{761}$ A further member stipulated that a greater emphasis on outcomes would improve Parliament's ability to assess the impact of government expenditure on society. Information on, and measurements of sustainability, happiness and wellbeing should be included with the financial data. Achieving effective linkages between government expenditure represented in outputs with the outcomes it aims to achieve has been an on-going challenge. ${ }^{762}$ Despite the apparent difficulty, further work should be put into improving outcome specification. It was argued by one interviewee that 'the next challenge on the horizon is how we can use financial and non-financial information to better inform strategic decision making'. ${ }^{763}$ If Parliament is to participate in that evolution it will need better outcome information.

\footnotetext{
${ }^{760}$ Newbery and Pallot, 'Wolf in Sheep's Clothing?', p. 270.

${ }^{761}$ Interview with anonymous MP, 23 January 2013.

762 Norman, Obedient Servants, p. 71.

${ }^{763}$ Interview with anonymous interviewee, 14 December 2012.
} 


\section{Financial Statements and Accounting}

\section{Review presentation of Financial Statements and Accounting Standards}

The presentation of financial statements and accounting standards should be reviewed to ensure that they meet the needs of their users. MPs currently struggle to understand the financial statements presented to Parliament. As stated by one member the government's accounts must be accessible and avoid unnecessary complexity. There is considerable risk in changing the financial statements. A balance must be achieved that allows for MPs and the wider public to scrutinise government expenditure while also providing sufficient detail for control. There may actually be little room for modifying the financial statements. The solution then is to improve MPs' ability to comprehend their contents. As put by Newberry and Pallot 'they need to be educated in accounting matters and their significance for the democratic process'. ${ }^{764}$ There was a strong call from members for the government's accounting standards to be reviewed. They want a review to examine how appropriate the current standards are for the government and the public sector, predominantly for smaller entities. There was also strong support for better reconciliation of international financial reporting standards (IFRS) with the needs of the government and the public sector. The government's accounting system should be analysed to determine what it must aim to attain from first principles and how that can be done.

\section{Parliamentary Process}

\section{Improve the Quality of Debate}

Debates in the House are where there is the most potential to improve Parliament's performance. Unfortunately that is the case because it is where Parliament's efforts are most inadequate. Unlocking that potential is problematic. It has been suggested that an increase in the size of Parliament would reduce speaking demands on MPs and allow them 'to be better informed and prepared when they speak'. ${ }^{765}$ Several members were firmly of the opinion that there is little that can be done to improve the quality of debate on the Budget, the Estimates and financial reviews. It will require a change in political culture. The contention was made that the Estimates debate would be useful if it more thoroughly examined what would be the most effective way to use government expenditure to achieve the government's desired

\footnotetext{
${ }^{764}$ Newberry and Pallot, 'A Wolf in Sheep's Clothing?', p. 275.

${ }^{765}$ Royal Commission on the Electoral System, Report of the Royal Commission, p. 126.
} 
policy outcomes. However, debate should also examine the appropriateness of the outcomes that the government is seeking. The likelihood of such a debate was described as 'pie in the sky'. ${ }^{766}$ Having such a debate is unlikely due to the adversarial and confrontational nature of Parliament. As provided by the member it would require MPs to put aside party politics and operate on their conscience. The speaking time and debate lengths should remain as is. The focus should be on improving the quality of the debate.

\section{Controller and Auditor-General}

\section{Relationship with Parliament}

The Auditor-General does not require major reform but there should be tweaks made to ensure that it is fully utilised to Parliament's benefit. As stated by one interviewee there are no reforms required to the Auditor-General's current platform for performing its work. Parliament must be cautious to tinker with the Auditor-General because of the risk of turning it into a 'whipping boy on everything or a political activist' ${ }^{767}$ However, Parliament, and the Auditor-General must clarify and develop greater understanding of each other's work and their expectations of what their relationship should entail. Clarification is needed of what the Auditor-General should be delivering for Parliament, and how the work of the Office may best be utilised by the House and select committees. There are a number of areas where both aspects can be improved. The reports and briefings produced by the Auditor-General must better fit the needs of MPs. The House and select committees should be more receptive of, and give greater attention to, reports from the Auditor-General. If necessary the Finance and Expenditure Committee (FEC) subcommittee to consider and process the Auditor-General's reports should be re-established. A further step would be to introduce an annual debate on reports from the Auditor-General following the presentation to the House of its annual report. An annual debate on the Auditor-General's report could follow the practice for that on the budget policy statement, and replace the next General Debate following its presentation. The Auditor-General should improve the public's ability to report instances of apparent waste in the public sector. However, such an expansion will required additional funding from Parliament. In general the Auditor-General should receive additional funding to expand and further develop its work.

\footnotetext{
766 Anonymous MP, 23 January 2013.

${ }^{767}$ Interview with anonymous MP, 31 November 2012.
} 


\section{Finance and Expenditure Committee}

\section{Inquiries}

The FEC should be undertaking more inquiries. There were consistent requests from opposition members for the FEC to have the ability to launch inquiries more frequently. The government must provide the FEC and the other select committees with some freedom to launch inquiries into matters that they believe are of concern. Members were quite broad in the areas that they believed inquiries should concentrate on. There was the preference that inquiries, rather than concentrating on accounting and auditing, focus on issues relating to the delivery of outcomes and the efficiency and effectiveness of government expenditure. Inquiries were perceived as appropriate by one member if they are only used in specific instances, including examining alternatives to new and existing expenditure. A further member would like the FEC to examine macroeconomic issues and the government's broader fiscal strategy. There was significant resistance to the FEC undertaking more inquiries only due to the committee's and MP's lack of time to undertake further work themselves. One member was concerned about the vast amount of work the FEC must already tackle. Instead the member argued that the FEC should spend more time considering in greater depth its current workload. A further member was blunt, stating that inquiries may make MPs appear more effective from a Wellington point of view, but the time that they consume is at the expense of maintaining the important connection with those that they represent.

There are options available to Parliament that could allow the FEC to carry out further inquiries. Utilising non-sitting or recess weeks, following the practice of the Public Expenditure Committee (PEC), was for the most part rejected. Most members argued that meetings during non-sitting weeks are only appropriate for providing existing matters additional time or when there is a lot of critical business to undertake. Further work, including inquiries in non-sitting weeks, was seen as an ineffective use of MPs' time considering their other obligations. However, there was strong support from some members who saw merit in further utilising non-sitting weeks. The general consensus was that the focus must be on using sitting weeks effectively with the suggestion made that select committees should have greater ability to meet while the House is sitting. The problem with any additional meetings is the extra preparation required of MPs, and the resources required to facilitate them. Thought should be given to using subcommittees, as was the practice of the PEC, despite the issues identified with their usage in the previous chapter. A further option is to introduce a separate Public Accounts Committee (or similar) tasked with undertaking 
inquiries. Members were opposed to changing the select committee structure for the reasons stated previously. The primary concern was that Parliament does not have a sufficient pool of expertise for an alternative structure or to split current responsibilities. A larger Parliament could provide for the extra MPs required to make a separate Public Accounts Committee more feasible.

\section{Annual Report and Debate}

The FEC should produce a report on its performance and that of the other select committees on matters relating to the control and scrutiny of government expenditure. The FEC does not report on its own performance or that of the other select committees that undertake work referred to them. ${ }^{768}$ An annual report from the FEC could state what Estimates and financial review examinations were undertaken, what inquiries it undertook, and how many AuditorGeneral reports were referred to the FEC and received select committee examination. Performance information could also be presented, such as the timeliness of committee reports, the level of public participation in the committee's processes, including submissions received, and the percentage adoption rate of its recommendations by the government. ${ }^{769}$ McGee has argued that legislatures should hold a debate on the work of their PAC. ${ }^{770}$ The majority of the FEC's work is available to debate in the House but it would be beneficial to have a dedicated debate each year on the committee's work. A debate on the FEC's annual report could be arranged, using the same practice as that recommended for the AuditorGeneral's annual report.

\section{Assistance}

Research, advisory and support services to Parliament should receive additional funding. There was a strong demand for MPs and select committees to receive greater assistance in order to improve their ability to perform the role. It was requested that the FEC and parliamentarians should have better access to economic advice and background research and briefings for the business before them. The argument was made that the Speaker should take greater responsibility for ensuring that Parliament, and especially select committees, are properly resourced. It was acknowledged that a lot is spent on Parliament already with most bases covered, but it is foolish to 'skimp' on the little bit extra to ensure that Parliament is

\footnotetext{
768 Jacobs, Jones and Smith, 'Public Accounts Committees in Australasia', p. 43

${ }^{769}$ KPMG, The Parliamentary Public Accounts Committee, p. 46.

${ }^{770} \mathrm{McGee}$, The Overseers, p. 8.
} 
well run. ${ }^{771}$ Although MPs are well served by the Auditor-General the greater availability of officials from departments and the Treasury was identified as a way to improve scrutiny of the Estimate documentation. It was argued that the opposition must be armed with their own independent analysis to challenge that provided to the government by departments. One member was not in favour of further staff and resources for select committees because any extra resources would be wasted on select committees that are not prepared to do their job. However, given the extensive workload placed on MPs it seems appropriate that further targeted assistance be provided.

\section{Parliamentary Budget Office and Independent Fiscal Council}

Providing further assistance through a Parliamentary Budget Office was not supported by the majority of members. A Parliamentary Budget Office is a 'nonpartisan, independent, objective analytic unit' that supports legislatures 'in both enacting and overseeing implementation of the Budget'. ${ }^{772}$ Members would appreciate greater resources but such an office was not perceived as necessary, and there were further significant reservations. Confidence was expressed in the current form of assistance provided to MPs by the AuditorGeneral, the Treasury, MPs own offices, party research units, the Parliamentary Library, and the specialist advisors that committees can request. There were concerns about a role conflict between the Auditor-General and a Parliamentary Budget Office. It was felt that the AuditorGeneral's undertaking of performance audits and inquiries, the type of work that could be expected of a Parliamentary Budget Office, made the latter unnecessary. There were claims that conflict is unlikely because the Budget Office would examine macro-economic or overall fiscal strategy while the Auditor-General would have a narrower audit or micro-economic role. It was argued that the office would likely develop into another captured quango and additional bureaucracy. There was further resistance on cost grounds with Parliament not having the size or funding available to justify every form of financial advice.

There was some backing for the creation of a Parliamentary Budget Office or a similar entity. A minority of members saw a Parliamentary Budget Office as potentially offering significant benefit to Parliament's ability to scrutinise government expenditure. A member, who was strongly in favour, believes such an office should provide MPs with the ability to submit issues for consideration while also having its own work programme. A further

\footnotetext{
${ }^{771}$ Interview with anonymous MP, 8 November 2012.

772 John Johnson and Rick Stapenhurst, 'The Growth of Parliamentary Budget Offices', in Shah, Performance, Accountability and Countering Corruption, p. 359.
} 
member supported the creation of such an entity because it would help MPs to have independent economic and fiscal advice at all times, and not just when certain items of business were before select committees. The contention was made because the level of analysis required was beyond what party research units and other current forms of assistance can offer. A further member believed that a full Parliamentary Budget Office was excessive, but that a special unit within an existing entity could provide the economic and financial advice desired. The Treasury has considered creating an Independent Fiscal Council to try to increase the public debate on fiscal policy by 'providing ex-post commentary on fiscal strategy and the macroeconomic stability dimension'. ${ }^{773}$ Parliament should consider the creation of such an Independent Fiscal Council to address the apparent shortfall in economic and fiscal advice.

\section{Spending Cap}

A legislative spending cap has been proposed to limit the growth of government expenditure. ${ }^{774}$ The proposed reform, contained in the confidence and supply agreement between the National and ACT parties, would have a major impact on Parliament's control and scrutiny of government expenditure. ${ }^{775}$ The proposed cap would limit government expenditure increases, with exceptions, to 'the annual increase in the rate of population growth multiplied by the rate of inflation'. ${ }^{776}$ All members who were interviewed were opposed to the introduction of a spending cap with extensive reasoning provided for their dismissal of the idea. They were labelled as 'blunt' and 'crude' tools that are both unconstitutional and impractical. ${ }^{777}$ Spending caps were identified as having a 'disastrous' impact internationally on infrastructure and investment in a jurisdiction's future. ${ }^{778}$ Constitutionally they are inappropriate because they attempt to bind future Parliaments. Elections are the appropriate means to check and change government expenditure patterns.

\footnotetext{
773 The Treasury, 'Regulatory Impact Statement for Amendment to Part 2 of the Public Finance Act 1989 (the fiscal responsibility provisions)', August 2012, http://purl.oclc.org/nzt/o-1476 (24 October 2012), p. 8.

${ }^{774}$ For analysis of spending cap proposals see: Tracy Mears, Gary Blick, Tim Hampton and John Janssen, 'Fiscal Institutions in New Zealand and the Question of a Spending Cap', November 2010, http://www.treasury.govt.nz/publications/research-policy/wp/2010/10-07/twp10-07.pdf (19 July 2012); Wilkinson, 'Restraining Leviathan', pp. 49-65; The Treasury, 'Regulatory Impact Statement for Spending Cap (People's Veto) Bill', April 2011, http://www.treasury.govt.nz/publications/informationreleases/ris/pdfs/ris-tsyscpvb-aug11.pdf (24 October 2012).

775 'Confidence and Supply Agreement with ACT New Zealand', in Jon Johansson and Stephen Levine (eds.), Kicking the Tyres: The New Zealand General Election and Electoral Referendum of 2011 (Wellington: Victoria University of Wellington Press, 2012), p. 391.

776 ibid.

777 Interview with anonymous MP, 30 January 2013; Anonymous MP, 23 January 2013; Anonymous MP, 28 November 2012; Interview with anonymous MP, 6 November 2012.

${ }^{778}$ Anonymous MP, 2 November 2012.
} 
Spending caps were also seen to constrain the ability of governments to govern and manage circumstances that are often beyond their control. It was firmly put by one member that artificial constraints should not be implemented to meet the ideology of one part of the political spectrum that could limit Parliament's sovereignty in the future.

Although a spending cap was thoroughly refuted, alternatives were proposed. Several members acknowledged and supported the rhetoric and principle behind such a measure but were strongly opposed to introducing a spending cap on constitutional grounds. They believe that governments must be transparent about their future expenditure intentions. There was consensus that any limits placed on expenditure must be set by governments themselves and not foist upon them by Parliament. Guidelines or principles were seen as more appropriate whereby the government would be required to explain significant increases of decreases in expenditure or be required to set out its future expenditure intentions. A further alternative provided was a system whereby public opinion is more directly engaged on significant increases in expenditure. Such a measure appears cumbersome with New Zealand's representative democracy. Members were adamant that any spending cap or alternative measure must have contingencies for emergencies and disasters because governments require flexibility in how they respond to the circumstances before them.

\section{Public Finance Amendment Act 2013 and Public Finance (Fiscal Responsibility)} Amendment Act 2013

Parliament has recently examined and passed the Public Finance Amendment Act 2013 and the Public Finance (Fiscal Responsibility) Amendment Act 2013. The Public Finance (Fiscal Responsibility) Amendment Act 2013 introduces four new fiscal responsibility principles, including 'when formulating fiscal strategy, having regard to its likely impact on present and future generations'. ${ }^{779}$ Such a principle could improve Parliament's ability to scrutinise the long term impact of government expenditure. Members stipulated that they were comfortable with the existing principles and did not believe that changes were necessary. There was reluctance to change the principles due to the risk of lurching between sets by different governments. Changes are made to the fiscal strategy report and the budget policy statement and a new investment statement is being introduced. ${ }^{780}$ The Public Finance Amendment Act

\footnotetext{
${ }^{779}$ New Zealand Parliament, 'Public Finance (Fiscal Responsibility) Act 2013', 3 September 2013, http://legislation.govt.nz/act/public/2013/0067/17.0/DLM4681505.html (10 October 2013). s.4. 780 ibid, s.5-s. 10 .
} 
2013 makes significant and widespread changes to the Public Finance Act $1989 .{ }^{781}$ It is not feasible to fully describe the modifications, but there are significant changes as to how appropriations must be specified, the contents of the Estimates and the supporting information, and the reporting requirements of departments and offices of Parliament. All changes will have been implemented by the middle of 2014. The alternations have great theoretical potential to improve Parliament's control and scrutiny of government expenditure, but it is far too early to pass judgment on what impact they will have in practice.

\section{Summary of Recommendations}

It is recommended that Parliament consider the following reforms to improve its ability to control and scrutinise government expenditure

- Expand to 150 MPs.

- Extend the parliamentary term to four years.

- Review Estimates documentation.

- Require better outcome specification and measurements of delivery.

- Review the financial statements and accounting standards.

- Improve MPs' access to training on accounting matters.

- Change the nature of debates on the Budget, Estimates and financial reviews.

- Review the relationship between Parliament and the Auditor-General.

- Require the Auditor-General to produce briefings better suited to the needs of select committees.

- Introduce an annual debate on the Auditor-General's annual report.

- Increase the funding to the Auditor-General and other assistance services provided to MPs.

- Additional funding to the Auditor-General should also be provided to improve the public's ability to report on apparent waste in the public sector.

- Further inquiries should be carried out by the FEC. Subcommittees or a separate Public Accounts Committee may be necessary to facilitate that.

- Have the FEC present an annual report.

- Consider creating a Parliamentary Budget Office or an Independent Fiscal Council.

\footnotetext{
${ }^{781}$ New Zealand Parliament, 'Public Finance Amendment Act 2013', 17 July 2013, http://www.legislation.govt.nz/act/public/2013/0050/latest/DLM5326005.html (10 October 2013).
} 
- Do not enact a spending cap but consider alternative options.

- The FEC should review the changes made by the Public Finance Amendment Act 2013 and the Public Finance (Fiscal Responsibility) Act 2013. Such a review should occur after the changes have been applied to a full financial year. 


\section{Bibliography}

Aitken, Judith, Public Expenditure Planning in New Zealand (Ph.D., Victoria University of Wellington, 1983).

Interview with anonymous interviewee, 20 November 2012.

Interview with anonymous interviewee, 14 December 2012.

Interview with anonymous MP, 23 October 2012.

Interview with anonymous MP, 2 November 2012.

Interview with anonymous MP, 6 November 2012.

Interview with anonymous MP, 8 November 2012.

Interview with anonymous MP, 15 November 2012.

Interview with anonymous MP, 28 November 2012.

Interview with anonymous MP, 31 November 2012.

Interview with anonymous MP, 23 January 2013.

Interview with anonymous MP, 30 January 2013.

Audit Office, Central Government Management: A New Approach (Wellington: Audit Office, 1989).

Ball, Ian, 'Changes in Accounting and Auditing Practices: The New Zealand Experience', in John Foster and John Wanna (eds.), Budgetary Management and Control: The Public Sector in Australasia (Melbourne: Macmillan Australia, 1990), pp. 128-141.

Beck, A.J., L.J. Downey, K. Hayes, and G.E. Wood, The Control of Government Expenditure in New Zealand (School of Public Administration, Victoria University of Wellington, 1962).

Boston, Jonathan and Stephen Church, 'The Budget Process in New Zealand: Has Proportional Representation Made a Difference', Political Science, Vol. 54, No. 2 (2002), pp. 21-43. 
Boston, Jonathan, 'Financial Management Reform: Principles and Practice in New Zealand', Public Policy and Administration, Vol. 8, No. 1 (1993), pp. 14-29.

Carpenter, D A, 'Origins of the Commons, Magna Carta to 1307', in Robert Smith and John Moore (eds.), The House of Commons: seven hundred years of British tradition (London: Smith's Peerage, 1996), pp. 26-47.

Chubb, Basil, The Control of Public Expenditure: Financial Committees of the House of Commons (Oxford: Clarendon Press, 1952).

'Confidence and Supply Agreement with ACT New Zealand', in Jon Johansson and Stephen Levine (eds.), Kicking the Tyres: The New Zealand General Election and Electoral Referendum of 2011 (Wellington: Victoria University of Wellington Press, 2012), pp. 389-396.

Controller and Auditor-General, 'All about the Controller and Auditor-General', February 2012, http://www.oag.govt.nz/about-us/frequently-asked-questions/controller-andauditor-general.pdf (26 July 2012).

Controller and Auditor-General, 'Central Government: Results of the 2003-04 Audits', B.29[05a], (March 2005), http://www.oag.govt.nz/2005/2003-04/docs/centralgovt.pdf (17 July 2013).

Dale, Tony, 'The Budget Process', in Alan Simpson, The Constitutional Implications of $M M P$, Occasional Publication No. 9 School of Political Science and International Relations, (Wellington: Victoria University of Wellington, 1998), pp. 236-253.

Education and Science Committee, '2010/11 Estimates for Vote Education and Vote Education Review Office', July 2010, http://www.parliament.nz/resource/0000114925 (18 September 2012).

Egan, J.P., H.J. Wakelin, and J. Yuill, Parliamentary Control of Public Expenditure in New Zealand (Diploma of Public Administration, Victoria University of Wellington, 1968).

Einzig, Peter, The Control of the Purse: progress and decline of Parliament's financial control (London: Secker \& Warburg, 1959).

Hallam, Henry, The Constitutional History of England (New York: Garland Publishing, 1978).

Jacobs, Kerry, Kate Jones \& David Smith, 'An Analysis of the Sources of Public Accounts Committee Inquiries: The Australian Experience', Australasian Parliamentary Review, Vol. 25, No. 1 (Autumn 2010), pp. 17-31. 
Jacobs, Kerry and Kate Jones, 'Governing the Government: The Paradoxical Place of the Public Accounts Committee', Australasian Parliamentary Review, Vol. 21, No. 1 (Autumn 2006), pp. 63-79.

Jacobs, Kerry, Kate Jones and David Smith, 'Public Accounts Committees in Australasia: The state of play', Australasian Parliamentary Review, Vol. 22, No. 1 (Autumn 2007), pp. 28-43.

Jacobs, Kerry, 'Value for Money Auditing in New Zealand: Competing for control in the public sector', British Accounting Review, Vol. 30, No. 4 (December 1998), pp. 343360.

Jackson, Keith, The Dilemma of Parliament (Wellington: Allen and Unwin, 1987).

Jackson, Keith, 'New Zealand Parliamentary Committees: Reality and Reform', the Parliamentarian, Vol. 29, No. 2 (1978), pp. 94-101.

James, Colin, Under New Sail: MMP and Public Servants (Wellington: Institute of Policy Studies, 1997).

Janssen, John, 'New Zealand's Fiscal Policy Framework: Experience and Evolution', December 2001, http://www.treasury.govt.nz/publications/researchpolicy/wp/2001/01-25/twp01-25.pdf (18 July 2012).

Johnson, John, and Rick Stapenhurst, 'The Growth of Parliamentary Budget Offices', in Anwar Shah (ed.), Performance, Accountability and Countering Corruption (Washington DC: World Bank Institute, 2007), pp. 359-378.

Jones, Kate and Kerry Jacobs, 'Public Accounts Committees, New Public Management, and Institutionalism: A Case Study', Politics and Policy, Vol. 37, No. 5 (2009), pp. 10231046.

KPMG, The Parliamentary Public Accounts Committee: An Australian and New Zealand Perspective (Canberra: KPMG, 2006).

Lipson, Leslie, The Politics of Equality: New Zealand's Adventures in Equality (Chicago: The University of Chicago Press, 1948).

Leo, Ann Puat, The Role of the Public Expenditure Committee and the Audit Office in the Policy Making and Administrative System in New Zealand (Masters of Public Policy Research Paper, Victoria University of Wellington, 1978). 
Martin, John, The House: New Zealand's House of Representatives, 1854-2004 (Palmerston North: Dunmore Press, 2004).

McGee, David, Parliamentary Practice in New Zealand (Wellington: Government Printer, 1985).

McGee, David, Parliamentary Practice in New Zealand, Third Edition, (Wellington: Dunmore Publishing, 2005).

McGee, David, The Budget Process: A Parliamentary Imperative (London: Pluto Press, 2007).

McGee, David, The Overseers: Public Accounts Committees and Public Spending (London: Pluto Press, 2002).

McLeay, Elizabeth, 'Parliamentary Committees in New Zealand: A house continuously reforming itself?', Australasian Parliamentary Review, Vol. 16, No.2 (Spring 2001), pp. 121-139.

McRobie, Alan, 'Parliamentary 'Control' of Public Expenditure', in Stephen Levine (ed.), Politics in New Zealand: A Reader (Sydney: George Allen \& Unwin, 1978), pp. 115130.

McRobie, Alan, 'The New Zealand Public Expenditure Committee', Political Science, Vol. 26, No. 1 (1974), pp. 28-46.

McRae, Tom, A Parliament in Crisis: The Decline of Democracy in New Zealand (Wellington: Shieldaig Productions, 1994).

Mears, Tracy, Gary Blick, Tim Hampton and John Janssen, 'Fiscal Institutions in New Zealand and the Question of a Spending Cap', November 2010, http://www.treasury.govt.nz/publications/research-policy/wp/2010/10-07/twp1007.pdf (19 July 2012).

Moore, John, 'Introduction', in Robert Smith and John Moore (eds.), The House of Commons: seven hundred years of British tradition (London: Smith's Peerage, 1996), pp. 1-25.

Muldoon, Robert, 'The Control of Public Expenditure in New Zealand', the Parliamentarian, Vol. 55, No. 2 (1974), pp. 79-85.

Newberry, Susan and June Pallot, 'A Wolf in Sheep's Clothing? Wider Consequences of the Financial Management System of the New Zealand Central Government', Financial Management \& Accountability, Vol. 21, No. 3 (August 2005), pp. 263-277. 
Newberry, Susan, 'Whole of Government Accounting in New Zealand: A Review of WGA Financial Reports From 1993 to 2010', Abacus, Vol. 47, No. 4 (2011), pp. 501-524.

Newberry, Susan and Sonja Pont-Newby, 'Whole of government accounting in New Zealand: the ownership form of control', Public Money \& Management, Vol. 29, No. 4 (May 2009), pp. 235-242.

New Zealand House of Representatives, 'Standing Orders of the House of Representatives 2011', 5 October 2011, http://www.parliament.nz/resource/0000238125 (21 July 2012).

New Zealand Parliament, 'Bill of Rights Act 1688', 1 January 1989, http://www.legislation.govt.nz/act/imperial/1688/0002/latest/DLM10993.html (7 June 2013).

New Zealand Parliament, 'Constitution Act 1986', 17 May 2005, http://www.legislation.govt.nz/act/public/1986/0114/latest/DLM94204.html (7 June 2013).

New Zealand Parliament, 'Crown Entities Act 2004', 8 August 2013, http://www.legislation.govt.nz/act/public/2004/0115/latest/DLM329631.html (28 September 2013).

New Zealand Parliament, 'Financial Reporting Act 1993', 14 September 2013, http://www.legislation.govt.nz/act/public/1993/0106/latest/DLM323598.html (28 September 2013).

New Zealand Parliament, 'Imperial Laws Application Act 1988', 5 August 2013, http://www.legislation.govt.nz/act/public/1988/0112/latest/DLM135074.html (7 June 2013).

New Zealand Parliament, 'Official Information Act 1982', 27 August 2013, http://www.legislation.govt.nz/act/public/1982/0156/latest/DLM64785.html (28 September 2013).

New Zealand Parliament, 'Public Audit Act 2001', 1 July 2012, http://www.legislation.govt.nz/act/public/2001/0010/latest/DLM88541.html (21 July 2012).

New Zealand Parliament, 'Public Finance Act 1989', 6 March 2013, http://www.legislation.govt.nz/act/public/1989/0044/latest/DLM160809.html (21 July 2012). 
New Zealand Parliament, 'Public Finance Amendment Act 2013', 17 July 2013, http://www.legislation.govt.nz/act/public/2013/0050/latest/DLM5326005.html (10 October 2013).

New Zealand Parliament, 'Public Finance (Fiscal Responsibility) Act 2013', 3 September 2013, http://legislation.govt.nz/act/public/2013/0067/17.0/DLM4681505.html (10 October 2013).

New Zealand Parliament, 'State-Owned Enterprises Act 1986', 30 August 2013, http://www.legislation.govt.nz/act/public/1986/0124/latest/DLM97377.html (28 September 2013).

Norman, Richard, Obedient Servants? Management Freedoms \& Accountability in the New Zealand Public Sector (Wellington: Victoria University of Wellington Press, 2003).

Norton, Phillip, Parliament in British Politics (Basingstoke: Palgrave MacMillan, 2005).

Officers of Parliament Committee, 'Code of Practice for the Provision of Assistance by the Auditor-General to the House, Select Committees and Members of Parliament', I.15C, August 2007, http://www.parliament.nz/resource/0000026015 (14 December 2012).

Office of the Clerk, 'Parliament's Annual Financial Cycle', June 2012, http://www.parliament.nz/resource/0000195069 (25 June 2013).

Pallot, June, 'A Wider Accountability? The Audit Office and New Zealand's Bureaucratic Revolution', in Susan Newberry (ed.), the Legacy of June Pallot: Public Sector Financial Management Reform (Greenwich: Information Age Publishing, 2006), pp. 261-289.

Pallot, June, 'Accounting, Auditing, and Accountability', in Susan Newberry (ed.), The Legacy of June Pallot: Public Sector Financial Management Reform (Greenwich: Information Age Publishing, 2006), pp. 55-87.

Pallot, June, 'Financial Management Reform', in Susan Newberry (ed.), The Legacy of June Pallot: Public Sector Financial Management Reform (Greenwich: Information Age Publishing, 2006), pp. 25-54.

Pallot, June, 'New Public Management Reform in New Zealand: The Collective Strategy Phase', in Susan Newberry (ed.), the Legacy of June Pallot: Public Sector Financial Management Reform (Greenwich: Information Age Publishing, 2006), pp. 219-239. 
Pallot, June and Ian Ball, 'What difference does resource accounting make? The case of New Zealand', in Dan Corry (ed.), Public Expenditure: Effective Management and Control (London: Dryden Press, 1997), pp. 237-252.

Palmer, Geoffrey, Unbridled Power: An Interpretation of New Zealand's Constitution \& Government (Wellington: Oxford University Press, 1979).

Palmer, Geoffrey, Unbridled Power: An Interpretation of New Zealand's Constitution and Government, Second Edition, (Auckland: Oxford University Press, 1987).

Palmer, Geoffrey, and Matthew Palmer, Bridled Power: New Zealand's Constitution and Government, Fourth Edition, (Auckland: Oxford University Press, 2004).

Palmer, Geoffrey, New Zealand's Constitution in Crisis (Dunedin: John McIndoe, 1992).

Payling, Simon 'The Later Middle Ages', in Robert Smith and John Moore (eds.), The House of Commons: seven hundred years of British tradition (London: Smith's Peerage, 1996), pp. 48-69.

Pelizzo, Riccardo, and Rick Stapenhurst, 'Strengthening Public Accounts Committees by Targeting Regional and Country Specific Weakness', in Anwar Shah (ed.), Performance, Accountability and Countering Corruption (Washington DC: World Bank Institute, 2007), pp. 379-393.

Pelizzo, Riccardo, Rick Stapenhurst, Vinod Sahgal and William Woodley, 'What Makes Public Accounts Committees Work? A Comparative Analysis', Politics \& Policy, Vol. 34, No. 4 (2006), pp. 774-793.

Polaschek, R.J., Government Administration in New Zealand (London: Oxford University Press, 1958).

Power, Timothy, The Financial Veto: Changing the rules of the Game (LLM, Victoria University of Wellington, 1996).

Preston, David, Government Accounting in New Zealand: an explanation of the accounting and financial system of the central Government of New Zealand (Wellington: Government Printer, 1980).

Richardson, Ruth, 'Opening and Balancing the Books: the New Zealand Experience', the Parliamentarian, (1994), pp. 244-246.

Ringer, J.B., An Introduction to New Zealand Government (Christchurch: Hazard Press, 1991). 
Royal Commission on the Electoral System, Report of the Royal Commission on the Electoral System: Towards a Better Democracy (Wellington: Government Printer, 1986).

Schick, Allen, 'The Spirit of Reform: Managing the New Zealand State Sector in a Time of Change', June 1996, http://www.ssc.govt.nz/sites/all/files/spirit_of_reform_all.pdf (27 July 2012).

Scott, Graham, 'New Zealand's Fiscal Responsibility Act', Agenda, Vol. 2, No. 1 (1995), pp. 3-16.

Scott, K.J., The New Zealand Constitution (London: Oxford University Press, 1962).

Shand, D.A., 'Parliamentary Control of the Public Purse- How Real', Journal of Public Administration, Vol. 34, No.2 (March 1972), pp. 59-73.

Skene, Geoff, 'Auditing, Efficiency and Management in the New Zealand Public Sector', Australian Journal of Public Administration, Vol. 44, No. 3 (September 1985), pp. 270-286.

Skene, Geoff, 'Parliamentary Reform', in Jonathan Boston and Martin Holland (eds.), The Fourth Labour Government: Radical Politics in New Zealand (Auckland: Oxford University Press, 1987), pp. 72-88.

Social Services Committee, '2010/11 Estimates For Vote Housing', 28 July 2010, http://www.parliament.nz/resource/0000114117 (18 September 2012).

Tanner, Ross, The Public Finance Act 1977 and Parliament's Control of Public Expenditure (LLM/MPP, Victoria University of Wellington, 1979).

The Finance and Expenditure Committee, 'Budget Policy Statement 2013 and Treasury's Half-year economic and fiscal update', I.3H, December 2012, http://www.parliament.nz/resource/0001871540 (3 November 2013).

The Treasury, 'A Guide to the Public Finance Act', August 2005, http://www.treasury.govt.nz/publications/guidance/publicfinance/pfaguide/ (20 July 2012).

The Treasury, 'Putting it Simply: an Explanatory Guide to Financial Management Reform', January 1989, http://www.treasury.govt.nz/publications/guidance/publicfinance/pis/ (20 July 2012). 
The Treasury, 'Putting it Together: An Explanatory Guide to the New Zealand Public Sector Financial Management System', June 1996, http://www.treasury.govt.nz/publications/guidance/publicfinance/pit/ (20 July 2012).

The Treasury, 'Putting it Together: An Explanatory Guide to New Zealand's State Sector Financial Management System', September 2011, http://purl.oclc.org/nzt/g-pit2011 (20 July 2012).

The Treasury, 'Regulatory Impact Statement for Amendment to Part 2 of the Public Finance Act 1989 (the fiscal responsibility provisions)', August 2012, http://purl.oclc.org/nzt/o-1476 (24 October 2012).

The Treasury, 'Regulatory Impact Statement for Spending Cap (People's Veto) Bill', April 2011, http://www.treasury.govt.nz/publications/informationreleases/ris/pdfs/ris-tsyscpvb-aug11.pdf (24 October 2012).

The Treasury, The Planning and Control of Government Expenditures: Planning, Programming and Budgeting System (Wellington: Government Printer, 1973).

Von Tunzelmann, Adrienne, 'Control of Expenditure and the New Zealand Public Expenditure Committee', the Parliamentarian, Vol. 59, No. 4 (1978), pp. 221-230.

Von Tunzelmann, Adrienne, 'The Public Expenditure Committee and parliamentary control of expenditure', Victoria University of Wellington Law Review, Vol. 10, No. 1 (February 1979), pp. 19-44.

Von Tunzelmann, Adrienne, The Public Expenditure Committee: The Process of Change 1962-1977 (M.P.P, Victoria University of Wellington, 1977).

Webb, Leicester, Government in New Zealand (Wellington: Department of Internal Affairs, 1940).

Webber, Carolyn and Aaron Wildavsky, A History of Taxation and Expenditure in the Western World (New York: Simon and Schuster, 1986).

Wilkinson, Bryce, 'Restraining Leviathan: A Review of the Fiscal Responsibility Act 1994', November 2004, http://www.treasury.govt.nz/downloads/pdfs/tfr-rl-1nov09.pdf (18 July 2012).

Wood, G.A., Governing New Zealand (Auckland: Longman Paul, 1988).

Wood, G.A. and Chris Rudd, The Politics and Government of New Zealand: Robust, Innovative and Challenged (Dunedin: University of Otago Press, 2004). 